Florida International University FIU Digital Commons

FIU Electronic Theses and Dissertations

University Graduate School

$11-10-2009$

\title{
Seed Dispersal and Reproduction Patterns Among Everglades Plants
}

Ronald E. Mossman

Florida International University, rmoss15101@aol.com

DOI: $10.25148 /$ etd.FI09120803

Follow this and additional works at: https://digitalcommons.fiu.edu/etd

Part of the Botany Commons, Plant Biology Commons, and the Terrestrial and Aquatic Ecology Commons

\section{Recommended Citation}

Mossman, Ronald E., "Seed Dispersal and Reproduction Patterns Among Everglades Plants" (2009). FIU Electronic Theses and Dissertations. 135.

https://digitalcommons.fiu.edu/etd/135

This work is brought to you for free and open access by the University Graduate School at FIU Digital Commons. It has been accepted for inclusion in FIU Electronic Theses and Dissertations by an authorized administrator of FIU Digital Commons. For more information, please contact dcc@fiu.edu. 
FLORIDA INTERNATIONAL UNIVERSITY

Miami, Florida

SEED DISPERSAL AND REPRODUCTION

PATTERNS AMONG EVERGLADES PLANTS

A dissertation submitted in partial fulfillment of the requirements for the degree of DOCTOR OF PHILOSOPHY

in

BIOLOGY

by

Ronald E. Mossman

2009 


\section{To: Dean Kenneth Furton}

College of Arts and Sciences

This dissertation, written by Ronald E. Mossman, and entitled Seed Dispersal and Reproduction Patterns Among Everglades Plants having been approved in respect to style and intellectual content, is referred to you for judgment.

We have read this dissertation and recommend that it be approved.

Bradley C. Bennett

Krish Jayachandran

Joyce Maschinski

Jennifer H. Richards

Joel C. Trexler

Suzanne Koptur, Major Professor

Date of Defense: November 10, 2009

The dissertation of Ronald E. Mossman is approved.

Dean Kenneth Furton College of Arts and Sciences

Dean George Walker University Graduate School

Florida International University, 2009 
(C) Copyright 2009 by Ronald E. Mossman

All rights reserved. 


\section{DEDICATION}

I dedicate this dissertation to my wife, Min Lum Mossman. Her ability to endure my numerous field trips and seed evaluation areas at our home site has been well beyond normal expectations. The completion of this study would not have been possible without her involvement, patience, and understanding. 


\section{ACKNOWLEDGMENTS}

I thank Jennifer Richards for suggesting Everglades seeds as my research area and for her general advice, support with the sawgrass germination study, and for the use of her lab equipment. Tom Philippi is thanked for his statistical abilities and guidance in planning and executing the seed analyses. The critical eye and thoughts of Joel Trexler were instrumental in the evolution of Chapter II. Brad Bennett is thanked for his provision of references on seed dispersal. I thank Joyce Maschinski for the detailed notes contributing to more focused statements. All members of my Committee are thanked for their time, patience, and endurance over the past several years. Finally, the final document would not have been possible without the critical eye and suggestions of Suzanne Koptur who enabled all three studies to become one coherent unit and directed all to completion. Thanks also go to several fellow graduate students and the Pope family—Leah, Peck, and Bob—who assistanted with collections. I thank my wife, Min Lum Mossman, for attending to my health concerns, her proof reading, and devoted accompaniment on numerous field trips.

Funding for much of my field equipment and material was made possible from a Howard Hughes Bridge Grant from Miami Dade College and the University of Miami, managed by Michael Gaines at U.M. and Robert Pope at M.D.C. Thanks also go to the Chemistry and Biology Departments at Miami Dade College for the use of their equipment. Access to field sites was granted by Everglades National Park under permit \# EVER 2002-SCI-0052 to Ronald E. Mossman. 


\section{ABSTRACT OF THE DISSERTATION \\ SEED DISPERSAL AND REPRODUCTION \\ PATTERNS AMONG EVERGLADES PLANTS}

by

\section{Ronald E. Mossman}

Florida International University, 2009

Miami, Florida

\section{Professor Suzanne Koptur, Major Professor}

In this study three aspects of sexual reproduction in Everglades plants were examined to more clearly understand seed dispersal and the allocation of resources to sexual reproductionspatial dispersal process, temporal dispersal of seeds (seedbank), and germination patterns in the dominant species, sawgrass (Cladium jamaicense). Community assembly rules for fruit dispersal were deduced by analysis of functional traits associated with this process. Seedbank ecology was investigated by monitoring emergence of germinants from sawgrass soil samples held under varying water depths to determine the fate of dispersed seeds. Fine-scale study of sawgrass fruits yielded information on contributions to variation in sexually produced propagules in this species, which primarily reproduces vegetatively.

It was hypothesized that Everglades plants possess a set of functional traits that enhance diaspore dispersal. To test this, 14 traits were evaluated among 51 species by factor analysis. The factorial plot of this analysis generated groups of related traits, with four suites of traits forming dispersal syndromes. Hydrochory traits were categorized by buoyancy and appendages enhancing buoyancy. Anemochory traits were categorized by diaspore size and appendages enhancing air movement. Epizoochory traits were categorized by diaspore size, buoyancy, and appendages allowing for attachment. Endozoochory traits were categorized by diaspore size, buoyancy, and 
appendages aiding diaspore presentation. These patterns/trends of functional trait organization also represent dispersal community assembly rules.

Seeds dispersed by hydrochory were hypothesized to be caught most often in the edge of the north side of sawgrass patches. Patterns of germination and dispersal mode of all hydrochorous macrophytes with propagules in the seedbank were elucidated by germination analysis from 90 soil samples collected from 10 sawgrass patches. Mean site seed density was $486 \mathrm{seeds} / \mathrm{m}^{2}$ from 13 species. Most seeds collected at the north side of patches and significantly in the outer one meter of the patch edge $(p=0.013)$.

Sawgrass seed germination was hypothesized to vary by site, among individual plants, and within different locations of a plant's infructescence. An analysis of sawgrass fruits with nested ANOVAs found that collection site and interaction of site $\mathrm{x}$ individual plant significantly affect germination ability, seed viability, and fruit size $(p \leq 0.050)$. Fruit location within a plant's infructescence did not significantly affect germination.

As for allocation of resources to sexual reproduction, only $17.9 \%$ of sawgrass seeds germinated and only $4.8 \%$ of ungerminated seeds with fleshy endosperm were presumed viable, but dormant. Collectively, only $22 \%$ of all sawgrass seeds produced were viable. 


\section{TABLE OF CONTENTS}

CHAPTER

PAGE

I. INTRODUCTION 1

Literature Cited 3

II. Functional Traits in Diaspore Dispersal: Phenological Patterns

and Physical Traits across Everglades Species 4

Dispersal Abstract 4

Introduction $\quad 5$

Materials and Methods $\quad 7$

$\begin{array}{lr}\text { Results } & 10\end{array}$

Discussion 13

Conclusions $\quad 17$

$\begin{array}{ll}\text { Literature Cited } & 20\end{array}$

III. Soil Seedbank Structure, And Vegetation Patterning In Shark River

Slough, Everglades National Park $\quad 38$

Seedbank Abstract $\quad 38$

Introduction $\quad 39$

Materials and Methods $\quad 41$

Results $\quad 44$

$\begin{array}{ll}\text { Discussion } & 47\end{array}$

Conclusions $\quad 54$

$\begin{array}{ll}\text { Literature Cited } & 57\end{array}$

IV. Fruit Size and Germination Probability in the Dominant Plant of the $\begin{array}{ll}\text { Everglades, Cladium jamaicense Crantz } & 72\end{array}$

$\begin{array}{ll}\text { Sawgrass Abstract } & 72\end{array}$

$\begin{array}{ll}\text { Introduction } & 72\end{array}$

$\begin{array}{ll}\text { Materials and Methods } & 74\end{array}$

$\begin{array}{lr}\text { Results } & 77\end{array}$

$\begin{array}{lr}\text { Discussion } & 79\end{array}$

$\begin{array}{lr}\text { Conclusions } & 82\end{array}$

$\begin{array}{ll}\text { Literature Cited } & 84\end{array}$

$\begin{array}{lll}\text { V. } & \text { CONCLUSION } & 97\end{array}$

$\begin{array}{ll}\text { APPENDICES } & 100\end{array}$

$\begin{array}{ll}\text { VITA } & 122\end{array}$ 


\section{LIST OF TABLES}

TABLE

PAGE

\section{CHAPTER II}

1. Summary of reproductive phenology data for plant life form categories by month at Shark River Slough, ENP

2. Seed and diaspore functional trait means for selected plant categories at Shark River

Slough, ENP

3. Means for major functional dispersal traits of 51 species by five seasonal dispersal categories in Shark River Slough, ENP 26

4. The factor scores generated from principle component analysis of 14 functional traits for 51 species of flowering plants in Shark River Slough, ENP..................... 27

5. Summary of functional dispersal trait suites..................................... 28

6. Summary of functional dispersal traits with enhancing diaspore features.................... 29

7. Potential hydrochorous dispersal distance of diaspores with varying masses.............. 30

\section{CHAPTER III}

1. Location of the 10 seedbank study sites in Shark River Slough, ENP.

2. Summary of number of species by patch Sides and Edges with mean seed densities...... 61

3. Summary of seedbank germination (seeding emergence) data by species............ 62

4. Mean germination densities of species by patch Side, Edge, and Site..................... 63

5. Total mean Site seed densities for nested categories in the 10 sawgrass patch sites....... 64

6. Summary of nested ANOVAs for seedling emergence from soil samples taken around sawgrass patches in Shark River Slough, ENP............................. 65

7. Summary of diaspore assay analysis from 25 randomly selected soil samples......... 66

8. Potential hydrochorous dispersal distance of diaspores with varying masses. 


\section{CHAPTER IV}

1. Collection sites of sawgrass, Cladium jamaicense, infructescences with site description and approximate hydroperiod......................................... 8

2. Mass and length for fruits, seeds germinated, and seeds viable for sawgrass............... 88

3. Nested ANOVA testing the effect of site, individual plant, infructescence location, and related covariates for significant effect on fruit mass, fruit length, number of

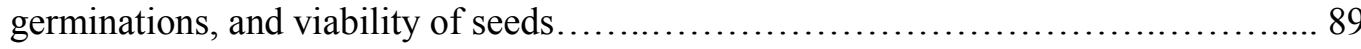

4. Distribution of germinations by site and five fruit mass categories.................... 90 


\section{LIST OF FIGURES}

FIGURE

PAGE

\section{CHAPTER II}

1. Diagrammatic representation of the ecological filtration process performed on

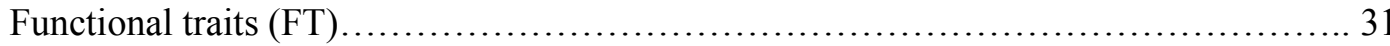

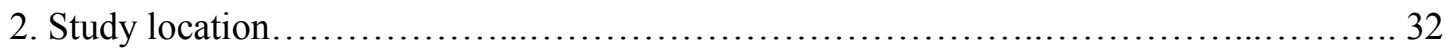

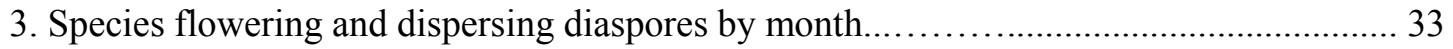

4. The number of species dispersing diaspores by month in each life form category............ 34

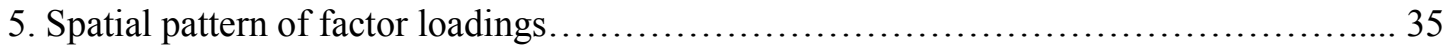

6. The buoyancy pattern for five representative species of 24 species tested................ 36

7. Eleocharis interstincta exhibits the potential for several forms of dispersal............... 37

\section{CHAPTER III}

1. Location of study areas in the NW edge of Shark River Slough, ENP..................... 68

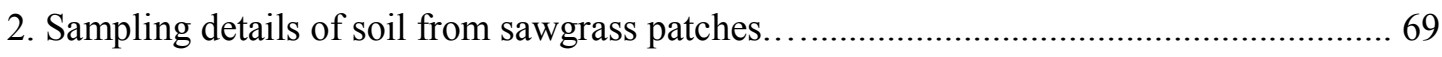

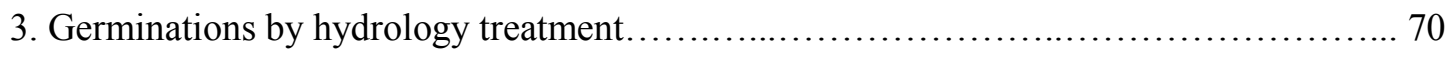

4. Comparison of the ENP seedbank species composition with a study done a few $\mathrm{km}$ north in flooded WCA-3A.................................................. 71

\section{CHAPTER IV}

1. South Florida map with sawgrass infructescence collection sites..................... 91

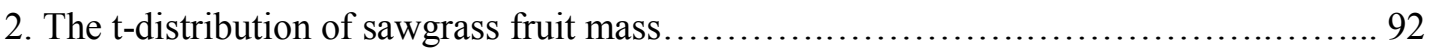

3. The pattern of all germinations over the 16-week (27 November 2005 to 19 March 2006) shade house study (a) and germinations by week according to fruit mass (b)........... 93

4. Cumulative sawgrass germinations during the 16 week study............................... 94

5. Pattern of fruit masses germinations by each week since planting.......................... 95

6. The paired t-tests for Cladium jamaicense fruits................................ 96 


\section{CHAPTER I}

\section{INTRODUCTION}

The Everglades environment is considered a disturbed or stressed ecosystem primarily as a result of its innate intra- and inter-annual variations in water supply and the impact of fire. Fluctuations in the depth of peat fires, together with the elevation of limestone bedrock, generate a vegetative mosaic resulting from variations in topography, substrate, and hydroperiod. Environment and disturbance have thus played an important role in shaping the communities of Everglades plants.

Over the past 5,000 years, the process of ecological filtration has selected for species from the original species pool possessing functional traits compatible with the changing environment (Gunderson 1994). The original species pool—most likely central Floridian pineland species (Craighead 1971)—was winnowed by this changing environment, by disturbance, and a biological filtration process. The species not possessing the requisite functional traits to survive the transition to the wetter environment were deleted (Keddy and Weiher 1999; Richardson 2009). The immigration of new species from the tropics also took place as the South Florida climate became more tropical, with wet and dry seasons (Long and Lakela 1971: Richardson 2009). This study examines three aspects of sexual reproduction among Everglades plants. It also attempts to deduce community assembly rules, patterns, and trends for seed dispersal in this ecosystem.

In marsh wetlands, both sexual and asexual reproduction function concurrently. Seeds initially colonize an area while species maintain their presence with asexual reproductiona less risky process - by allocating resources primarily to vegetative growth in a proven site. However, with fire or other adverse conditions, the limited seeds produced serve as a hedge against extermination. These few seeds provide for reestablishment or for colonizing new areas. 
Both forms of reproduction have a place in the Greater Everglades ecosystem (Fenner and Thompson 2005).

In the second chapter, I evaluate the functional species traits that enable and enhance seed dispersal in the Everglades. These traits sort into two categories that provide for spatial dispersal: dispersal timed with seasonal flooding and diaspore morphology traits that enhance dispersal. Dispersal syndromes are also defined by the functional dispersal traits shared by groups of species.

In the third chapter, temporal dispersal—seed dormancy—is examined. Sawgrass (Cladium jamaicense) patches dominate the Everglades. I therefore hypothesized that the edges of these elevated patches catch floating seeds, and cores of peaty substrate along their edges hold a seedbank in support of the seed-catching hypothesis. In disturbance-prone ecosystems seedbanks are more prevalent, while they are nearly absent in tropical forests where disturbances are rare (Parker et al. 1989). Species richness and seed density in sawgrass patches may reflect the importance of dispersal through time, as a hedge against the effects of severe disturbances, leaving the seedbank to recolonize.

The fourth chapter evaluates diaspore size variation and its effect upon germination ability in the dominant species — sawgrass. I looked for fruit size, seed germination, and viable seed variation in three areas: within different locations in the infructescence of individual plants; among different plants at the same site; and among different sites. This chapter serves as a measure of the allocation of resources to sexual reproduction for one species, Cladium jamaicense, and the influence of this allocation on enhanced survivability of the species.

Collectively, these chapters provide some understanding of the patterns encountered in seed/diaspore formation, dispersal, and germination in the Everglades. This study also initiates an effort to explain these processes according to the ecological assembly rule paradigm (Keddy and Weiher 1999). 


\section{LITERATURE CITED}

Craighead, F. C. 1971. The Trees of South Florida: Volume I - The Natural Environments and Their Succession. University of Miami Press. Coral Gables, FL. 212 pp.

Fenner, M. and K. Thompson. 2005. The Ecology of Seeds. Cambridge University Press. Cambridge, UK. 250 pp.

Gunderson, L. H. 1994. Vegetation of the Everglades: Determinants of community composition. Pgs. 323-340 in: Everglades: the Ecosystem and its Restoration, S.M. Davis and J. C. Ogden (eds.). St. Lucie Press. Boca Raton, FL.

Keddy, P. and E. Weiher. 1999. Introduction: The scope and goals of research on assembly rules. Pgs.1-20 in: W. Weiher and P. Keddy (eds.) Ecological Assembly Rules, Perspectives, Advances, Retreats. Cambridge Univ. Press, Cambridge, UK.

Long, R.W. and O. Lakela. 1971. A Flora of Tropical Florida: A Manual of the Seed Plants and Ferns of Southern Peninsular Florida. University Miami Press. Coral Gables, FL. 962 pp.

Parker, V. T., R. L. Simpson, and M. A. Leck. 1989. Pattern and process in the dynamics of seed banks. Pgs. 367-384 in: Ecology of Soil Seed Banks, M. A. Leck, V. T. Parker, and R. L. Simpson (eds.). Academic Press, Inc. NY, NY.

Richardson, C. J. 2009. The Everglades: North America's subtropical wetland. Wetlands Ecology and Management D01 10.1007/s11273-009-9156-4 


\title{
CHAPTER II
}

\section{FUNCTIONAL TRAITS IN DIASPORE DISPERSAL: PHENOLOGICAL PATTERNS AND PHYSICAL TRAITS ACROSS EVERGLADES SPECIES}

\author{
DISPERSAL ABSTRACT
}

In the northern Shark River Slough of Everglades National Park, 51 species were evaluated for functional traits - inherited characters that contribute to a process - thought to contribute to diaspore dispersal. Functional traits are a measurable consequence of an ecological filtration process that strongly influences organizational performance in ecological communities. Patterns among these traits help to explain community processes, such as diaspore (seed and allied matter) dispersal, and can lead to community assembly rules for dispersal traits.

Factor analysis of 14 functional dispersal traits indicated that traits related to diaspore size, buoyancy, and appendages on diaspores predominated. Diaspore dispersal peaked from July through September, and $71 \%$ of all species dispersed during the wet/flooded season (MayJanuary). Of the wet season dispersers, $20 \%$ released diaspores only from May through August, and 33\% released diaspores only from September through January. Among the three dominant higher plant life forms — graminoids, forbs, and woody plants_-graminoid dispersal peaked from July through October, forb dispersal peaked from April through August, and woody species dispersal peaked from August through January. Graminoids, and especially the Cyperaceae, have functional traits for hydrochory that could explain their role as wetland pioneer succession species. This study is the first effort to identify diaspore dispersal functional traits within the Everglades ecosystem, using community assembly rules.

KEY WORDS: Seed dispersal, hydrochory, Everglades, wetlands, community assembly rules, functional traits 


\section{INTRODUCTION}

In community assembly theory, local communities are formed by the sorting processes in a regional species pool based on functional traits that are connected to dispersal, survival, and reproduction (Keddy and Weiher 1999) (Fig. 1). Within each species are the functional traits that —working alone or together — define which form(s) of dispersal is/are available for the species (Fig. 1). The identification of suites of these functional traits can provide information on the origins of community structure (Diaz et al. 1999) and thus generate a framework for studies matching species distribution and environmental gradients (McGill et al. 2006). Patterns among these traits help to explain community processes such as diaspore (seed and allied matter) dispersal and can lead to community assembly rules for such dispersal (Drake et al. 1999). This study seeks to identify functional traits and dispersal trait patterns in the Everglades.

The Everglades basin began flooding with freshwater about 5,000 YBP (Gleason and Stone 1994). The temperate plant species of the Central Florida uplands that now persist in the Everglades ecosystem (Long and Lakela 1971) passed through an ecological process involving the biotic and abiotic filtering of species by functional traits (Diaz et al. 1999). Major abiotic drivers in the present Everglades ecosystem include climate and seasonal periodicities that are infused with extremes of hydrology, fire, and storm events (DeAngelis and White 1994; Casanova and Brock 2000). The typical rainy season in Southern Florida is from May to October, but the availability of surface water varies temporally and spatially, e.g., topographic heterogeneity allows pooled water into February or longer, and the quantity and frequency of rainfall contributes to the flow dynamics in the ecosystem.

When an upland ecosystem is transformed into a wetland, species with diaspore traits compatible with dispersal processes in this wetland have an advantage. The presence or 
absence of some form of hydrochory is such a trait, and would contribute to the sorting of species invading a new wetland. Major biotic functional traits among wetland species include buoyant diaspores (Leck and Schutz 2005; Lopez 2001) and diaspore size. The mean seed mass is a fairly uniform character in plant species (Fenner 1985), but typically the mass distributions have long tails (Fenner and Thompson 2005). There is a size/number trade-off in seed packaging: plants with small seeds producing more seeds than plants with large seeds. Small seeds are known to be better colonizers, and typically travel much farther than do larger ones (Harper et al. 1970; Howe and Smallwood 1982; Tiffney 1984; Jakobsson and Eriksson 2000). Large seeds may not travel far, but have greater certainty of producing seedlings that may win in competition with smaller-seeded species because seedlings from large-seeded plants are more robust (Harper 1977; Baker 1972). Traits controlling reproductive phenology commonly synchronize the timing of flowering and dispersal with appropriate environmental factors such as temperature, photoperiod, and hydrology (Fenner 1985).

Seed mass, dormancy, and dispersal traits have been found to vary as a syndrome in a seed adaptability model developed by Venable and Brown (1988). Seed traits of size, dispersal, and dormancy interact within this model. A decrease in one trait results in an increase in the other two traits, e.g., small-massed seeds should have less survivability than large-massed seeds, but such low survivability is compensated by increased dispersal and dormancy. The validity of this model among Everglades diaspores can be tested through the identification of functional traits for diaspore dispersal. This combination of traits may help explain patterns of colonization in disturbed, wetland environments such as the Everglades.

In this study, 14 traits from 51 species are examined in order to answer two questions: 1) What functional dispersal traits and functional trait suites guide the process of diaspore dispersal in Everglades marshes? 2) Are patterns of traits predicted by Venable and Brown's (1988) seed adaptability model for disturbed environments present in the Everglades' aquatic 
flora? In this study, I evaluate four types of dispersal: hydrochory (water), anemochory (wind/air), epizoochory (animal attached), and endozoochory (animal eaten).

\section{MATERIALS and METHODS}

\section{a. Study Site}

The northwestern edge of Shark River Slough at Everglades National Park was the area selected for the study. The actual site was located along the east side of the Shark River Slough Tram Road between mile markers 8 to 15 (from latitude $25^{\circ} 39.77^{\prime} \mathrm{N}$ to $25^{\circ} 45.21^{\prime}$ and generally between longitudes $80^{\circ} 45.50$ and $80^{\circ} 45.60 \mathrm{~W}$ ) south of the Shark River Slough entrance, Everglades National Park, Florida, USA (Fig. 2). Topographically, it is composed of depressions and elevations with marl and peat substrate and an elevation of 1.8 - 2.2 m (6-7 ft.) (Gleason 1974). Consequently, the vegetation is a complex mosaic of wetland communities, including wet prairie, tall sawgrass, sparse sawgrass, bald cypress, and tree islands with bayhead swamp around island perimeters; the major community is sparse sawgrass (Olmstead and Armentano 1997; Ross et al. 2001). Substrate beneath sawgrass is identified as sawgrass peat with marl, with thin marly peat lying beneath spikerush patches (Hofstetter and Hilsenbeck 1980). In USDA soil taxonomy, peaty soil is called saprist histosol (USDA 1999). Because of the great variability in soil composition, soil $\mathrm{pH}$ throughout Shark River Slough ranges from 6.3 to 8.0 (Ross et al. 2001; Olmstead and Armentano 1997). My study site was selected as a potentially productive area to study diaspore dispersal across a mixture of Everglades communities because of its accessibility and its inherent topographic and vegetative diversity.

Within the Koppen system of climate classification, South Florida is a tropical wet-dry savannah (Aw) with an average temperature each month $>17^{\circ} \mathrm{C}\left(64^{\circ} \mathrm{F}\right)$ (Strahler and Strahler 1998). The study area has an annual average temperature of $24^{\circ} \mathrm{C}\left(75^{\circ} \mathrm{F}\right)$, with January being 
the coldest month. The annual rainfall at the study site is $140-153 \mathrm{~cm}(55-60 \mathrm{in}$.) (Henry et al. 1994). 


\section{b. Reproductive Phenology Traits}

To determine flowering and fruiting seasons, all species encountered with flowers or mature fruit (dispersing) were recorded at mid-month from January to November 2003 and from June 2005 to June 2007 within a 10-meter belt transect east of the roadside embankment and into the glades, along east Tram Road (Fig. 2). Species along both sides of an east-west boardwalk, through a community dominated by willow (Salix caroliniana) and alligator flag (Thalia geniculata), were also evaluated at mid-month during the above period. In some cases, mature fruits were not available in adequate numbers for diaspore mass and buoyancy measurement because of herbivory or rarity of the species; however, flowering and dispersal seasons were recorded. Observations of dispersing diaspores and evidence for type of dispersal were recorded in the field. A few species were raised to maturity in the Landscape Technology Nursery at Miami Dade College, so that the dispersal unit could be determined, studied, and photographed.

The seed is usually not the dispersed unit. Rather, it is a combination of seed(s) and allied appendages such as fruit wall, scales, bristles, barbs, glumes. The term 'diaspore' is, therefore, more appropriate and is used as the generic term for the dispersed unit throughout this study. To determine diaspore mass, length, and buoyancy, mature diaspores were collected from three plants of each species and combined. In the laboratory, diaspores from each species were counted into two groups of 50 diaspores. The mean mass for the 100 was determined. Seed mass was determined in a like manner. When the mass was extremely small $(<0.05 \mathrm{mg})$, 100-200 seeds were used for greater accuracy. The mean length of seeds and diaspores were determined to the nearest $0.5 \mathrm{~mm}$, for 25 undamaged diaspores or seeds placed alongside a ruler's edge.

To determine buoyancy, two units of 25 or 50 diaspores or seeds of each species were placed in containers of water. The number floating was counted daily until such time as only 
$50 \%$ of the original number remained floating. This number of days was termed the $\mathrm{FD}_{50}$ (halflife of floating dispersal) and was the standard buoyancy unit. If diaspores lacked buoyancy, one day was recorded. If more than half yet floated at 30 days, an $\mathrm{FD}_{50}$ of 30 days was recorded.

To obtain a larger set of species variables to process for dispersal traits, 10 additional functional traits were recorded from field and laboratory observations. These were recorded in a binary format as either present (1) or absent (0) for each species. These 10 functional traits were: appendages that snag, appendages that enhance buoyancy, winged appendages, a pappus appendage, fleshy fruit covering, small diaspores high on culm (for potential zoochory), small diaspores that cluster on the water surface (for potential surface feeders), buoyant seeds, buoyant diaspores, and small diaspores capable of mixing with mud on feet (for potential epizoochory).

Factor analysis was used to identify patterns of correlation among the 14 functional traits. The iterated principal axis method (also called principal axis factoring and principal iterated factor) with varimax rotation (Krzanowski 2007; SPSS 1997) was used with SYSTAT 8.0 software. The iterated method generates a preliminary estimate of commonalities among variables (a technique similar to principal covariant analysis), a step not performed in the default PCA (principal component analysis) method (SPSS 1997). This additional iterated step can reduce the number of factor loadings required to explain variation, and can lead to a finer level of classification among functional traits in studies such as classifying plant communities and floral morphology (Fairbanks 2000; Dominguez et al. 1998). Before the analysis, each of the measured variables (mass, length, and buoyancy) for all species were summed and converted to proportional numerical values so that the 14 variables would all be more normally distributed, with a range between zero and one. 
Based on early diaspore and phenology observations, plants were sorted into four life form categories: graminoids, forbs, woody temperate, and woody tropical. In order to determine how dispersal timing matched environmental suitability for germination (hydrology), species were assigned one of five dispersal seasons based upon the results of field and diaspore observations: early wet (May-August), late wet (September- January), throughout wet (MayJanuary), dry (February-April), and general (all year). The monthly hydrology ranges recorded in this study may differ in exceptional years.

Several references provided pertinent morphological and dispersal information (Fassett 1968; Long and Lakela 1971; Correll and Correll 1972; Godfrey and Wooten 1979, 1981; van der Pijl 1982). Nomenclature is according to Wunderlin and Hansen (2003), with Godfrey and Wooten $(1979,1981)$ used for species determination. Vouchers of specimens were made and deposited in the Everglades National Park Herbarium. A 'seed atlas' of digital close-up photos of diaspores and dispersal information was produced for a seed and dispersal reference and included here as Appendix D.

\section{RESULTS}

\section{a. Phenological Patterns}

Flowering for all species peaked from April to July, and dispersal for all species peaked from July to September (Fig. 3). Of the 51 species studied, 41 were herbaceous (graminoids and forbs) (Table 1). Graminoid flowering peaked from May to November, and their dispersal peaked from July to November (Table 1). Forb flowering peaked from April to July, and their dispersal peaked from May to September. Temperate woody species flowering peaked from April to July, and their dispersal peaked August to December (Table 1). The sample size for woody tropical species $(\mathrm{N}=3)$ was too small to evaluate. Graminoid dispersal increased by more than $100 \%$ between May and July, coinciding with the onset of the rainy season. Forbs had a similar increase from March to June (Fig. 4). 
In the five dispersal season categories (Appendix C), 20\% of the species were limited to early wet season (May - August), 33\% were limited to late wet season (September - January), $18 \%$ dispersed throughout the wet season (May - January), and 28\% dispersed throughout the year. Only one species, sneezeweed (Helenium pinnatifidum), was limited to dry season dispersal (February - April) (Appendix B). Among seasonal dispersal categories, the mean dispersal mass was $174.2 \mathrm{mg}$ for dispersal throughout the wet season (category 3 ), a mass more than triple that of any other season (Table 3). The early wet season (category 1) diaspore mass was only $3.8 \mathrm{mg}$, the smallest of all dispersal seasons. However, this small mean mass is coupled with the largest diaspore mean buoyancy, 20.4 days. Buoyancy for both seeds and diaspores is statistically similar for all other seasonal categories with means of 8.8 to $10.9 \mathrm{mg}$ for seeds and 11.0 to $12.8 \mathrm{mg}$ for diaspores (Table 3).

\section{b. Mass, Length, \& Buoyancy.}

Seed and diaspore mass and buoyancy varied considerably among species (Appendix C). For all species, mean seed mass was $36.3 \pm 15.4$ S.E. $\mathrm{mg}$, and the mean diaspore mass was $54.9 \pm 34.6$ S.E. $\mathrm{mg}$ (Table 2$)$. The mean buoyancy $\left(\mathrm{FD}_{50}\right)$ for seeds was $11.4 \pm 2.3$ S.E. days, while the mean diaspore buoyancy was $13.4 \pm 2.2$ S.E. days (Table 2 ).

Among plant life forms diaspore mass differed greatly. The mean diaspore mass for graminoids $(2.1 \pm 1.01$ S.E. $\mathrm{mg})$ was the smallest of the four life form groups (forbs $=74.7 \pm$ $66.5 \mathrm{mg}$, woody temperate $=40.5 \pm 29.1$ S.E. $\mathrm{mg}$, woody tropical $=371 \mathrm{mg}$ ). The majority of the graminoid species (11 of 14) are members of the Cyperaceae family. This family contributed the smallest diaspores; the median mass for this family was only $0.9 \mathrm{mg}$ (Table 2). The plant life forms with the longest average diaspore buoyancies were forbs with a $\mathrm{FD}_{50}$ of 16.7 \pm 3.7 S.E. days and woody tropical species with a $\mathrm{FD}_{50}$ of 30 days (Table 2).

Among seasonal dispersal categories, species dispersing in the early wet season (May - August) had the longest mean $\mathrm{FD}_{50}$ diaspore buoyancy, $20.4 \pm 4.6$ S.E. days, as well as the 
smallest mean diaspore mass $(3.8 \pm 1.28$ S.E. $\mathrm{mg})$. Species that dispersed during the entire wet season (May - January) had the largest mean mass , but the smallest length, $174.2 \pm 171.7$ S.E. $\mathrm{mg}$ and $1.7 \mathrm{~mm}$, respectively (Table 3 ).

\section{c. Identifying Functional Traits and Suites}

Factor analysis among the 14 functional dispersal traits required only two factor loadings to explain $73.1 \%$ of the variation among the functional traits, and $99.9 \%$ was explained with three factor loadings. The highest factor scores $(\geq 0.4)$ relate to three diaspore traits: diaspore appendages, diaspore buoyancy, and diaspore/seed size (Table 4), which suggests close relationships of these three clusters of functional traits. Traits 1 - 3 relate to diaspore appendages, $4-7$ relate to buoyancy, and $8-11$ relate to seed size (Tables 4,5$)$.

The graphed score sets of (Factor 1 and Factor 2) and (Factor 1 and Factor 3) generally identified the same three functional trait clusters (Table 4, Fig. 5). While two traits stand alone, four clusters of two or more functional traits became delineated in the graphed scores resulting from the Factor 1 x Factor 2 loading (Fig. 5). However, with a Factor 1 x Factor 3 loading, some functional trait "mixing" occurred among trait families A, B and D (Table 5; Fig. 5). The following observations are therefore based only upon the Factor 1 x Factor 2 loading. In cluster $\mathrm{C}$, there are three appendage attributes: hooks, a pappus, and appendages that enhance buoyancy. This family of traits sits clearly apart from the other three families A, B, and D. Family A includes traits that relate to smaller diaspores. Family B includes traits related to buoyancy. Family D includes traits that relate to larger diaspores (Table 5).

\section{d. Some Buoyancy Observations}

A new sub-form of hydrochory was included after observing algal mat rafting, whereby seeds adhesively attach to, or fall upon, floating algal mats. The method of rafting dispersal has 
been named phycochory, and seeds with little or no buoyancy ability can opportunistically utilize this method for hydrochorous dispersal (Minchinton 2006).

Seed germination while floating may give some species a colonization advantage (Leck et al. 2008). All 50 seeds in the buoyancy test for water dropwort (Oxypolis filiformis) germinated while floating. A few lanceleaf arrowhead (Sagittaria lancifolia) seeds $(<10 \%)$ also germinated in buoyancy testing, and sawgrass (Cladium jamaicense) seeds have been observed germinating on floating algal mats (van der Valk and Rosburg 1997).

When changes in the diaspore buoyancy of 24 species were graphed over 40 days, five buoyancy patterns appeared (Fig. 6). If diaspores lacked buoyancy, they did not always quickly sink. Because of surface tension, the smaller ones floated longer than larger ones.

Among buoyant, large-seeded tropical woody species, cocoplum (Chrysophyllum icaco) and pond apple (Annona glabra) seeds were observed grounded and germinating on muddy exposed margins of tree islands in March, at the end of a lengthy wet season. During the same month, groups ( $c a .5 \mathrm{~cm}$ diameter) of temperate woody seedlings of redbay (Persea borbonia) and sweetbay (Magnolia virginiana) were observed beneath the peripheral trees of tree islands, the probable consequence of defecation after endozoochory.

\section{DISCUSSION}

The assembly mechanics of community structure are the regulatory agents and processes that define the suite of plausible stages or transitions through which the system moves (Drake et al.1999). The assembly process also includes historical events that have acted to drive the Everglades to its present state. These historical events include disturbances such as the rise of water level, climate changes since the last ice age, and biotic interactions (Fig. 1). Disturbance also includes anthropogenic manipulation, e.g., changes in the hydrology by drainage, compartmentalization, and control of water in general (South Florida Ecosystem Task Force 2000). 
For all species, functional dispersal traits are subsets of morphology traits and reproductive phenology or timing traits (Van der Pijl 1982). They are also a collective expression of community dispersal assembly. The functional traits that enhance each of the four major forms of dispersal have been identified by factor analysis. They are grouped as dispersal syndromes and include: hydrochory $=7$ traits; anemochory $=5$ traits; epizoochory $=9$ traits; and endozoochory $=12$ traits (Table 5$)$.

The sorting of species by major dispersal type is sometimes a simple process. For example, a diaspore with a fleshy fruit is clearly endozoochorous. Even if later the seeds fall into water upon defecation and are buoyant, the main dispersal syndrome is usually considered endozoochory. Thus, the species has a primary set of functional dispersal traits, as well as a secondary set of functional dispersal traits, which, as a back-up, provide another dispersal option (hydrochory). The extra dispersal advantage would result in enhanced survivability within a disturbance-prone environment such as the Everglades.

However, it is not as easy to place some species in a primary dispersal syndrome when two or more functional traits seem to have equal importance. In this situation, it may be more prudent to suggest a new dispersal concept, a polydispersal syndrome. Consider, for example, the jointed spikerush (Eleocharis interstincta) ( Fig. 7). The fruit of this species alone lacks buoyancy, but with six bristles and often entangled scales as appendages, buoyancy is imparted to groups of fruits. Additionally, the bristles are barbed, the persistent style is spiraled near the tip, and the persistent stigma is pubescent. All of these morphological traits infuse a 'snagging' potential useful in epizoochory, or in holding diaspores together for endozoochory, or, if on the water surface, hydrochory (Fig. 7). Other polydispersal syndrome examples include southern plains willow (Salix caroliniana) and cattail (Typha domingensis), which are usually dispersed by wind. Yet more methods of dispersal are possible, since their small-massed diaspores often disperse into shallow water. Their diaspores are buoyant due to surface tension of the attached 
pappus with water (van der Pijl 1982) allowing for hydrochory into muddy edges. The diaspores may also be eaten by surface-feeding waterfowl, or they may be carried away by epizoochory when diaspores adhere to waterfowl plumage or feet when mixed with mud (Vivian-Smith and Stiles 1994; van der Pij1 1982; Wongsriphuek et al. 2008). Although usually considered strictly anemochorous, with these other dispersal options, such species would exhibit the polydispersal syndrome. There are eight identified functional traits that enable polydispersal syndromes across three or more dispersal syndromes (Table 6).

The recent collection of pond apple (Annona glabra) seeds from alligator intestines by an alligator researcher adds a suprising addition to endozoochory. Pond apple seeds have been found in several alligators (10 - 40/alligator) (Adam Rosenblatt personal communication). Since Annona seeds have a waxy coating, their was no evidence of digestion. I was able to evaluate some removed seeds. Upon sectioning, both the seed endosperm and the embryo were fleshy and viable. Alligators could either consume floating pond apple fruit or eat fish that have ingested seeds. Pieces of crab exoskeleton and turtle skeleton are known to reside within the alligator gut for 30 days or more (Adam Rosenblatt personal communication). Since pond apple is dispersed only from mid August until early September, and the seeds were collected from the alligator on 20 October, the alligator had been holding them for 6-8 weeks. Holding seeds for several weeks greatly increases dispersal distance as alligators defecate while migrating and searching for prey.

Small diaspores without a pappus are common in graminoids and other genera. These small diaspores follow a similar dispersal scenario as the anemochorous species described above and include Cyperus, Rhynchospora, Scleria, Eleocharis, Juncus, Nymphaea, Nuphar, and Pontederia. They are typically dispersed via hydrochory but may also be dispersed by zoochory when they are eaten by surface-feeding ducks, caught on waterfowl plumage, or on 
muddy legs (Tabb 1964;Vivian-Smith and Stiles 1994; van der Pij1 1982; Wongsriphuek et al. 2008).

The wide distribution of Everglades species also found in Belize, Bahamas, Bermuda, and Venezuela inferentially supports the consequences of recorded avian endozoochory and epizoochory (Vivian-Smith 1994; Wongsriphuek et al 2008). For example, in a New Jersey study of epizoochory, $78 \%$ of waterfowl carried seeds $-84 \%$ on feathers and $16 \%$ in mud on their feet (Vivian-Smith and Stiles 1994). Species that probably were dispersed from North America by zoochory include: Sagittaria lancifolia, Utricularia foliosa, U. purpurea, and from Cyperaceae Cladium jamaicense, Eleocharis cellulosa, and E. interstincta ( Johnson 2004; Correll and Correll 1982; Gordon 1998).

This wide phytogeographical species distribution might also reflect the consequences of Venable and Brown's (1988) seed adaptability model for disturbed habitats. Applied to the species with small diaspores above, the species should have compensated for small and lesswell-provisioned diaspores, with enhanced dispersal and seed dormancy. Diaspores with hydrochorous dispersal and a mass $<2.0 \mathrm{mg}(\mathrm{n}=14)$ were graphed against their buoyancy as an expression of dispersal. By the seed adaptability model, diaspore mass is inversely related to dispersal. The model states that at low mass dispersal is highest (Venable and Brown 1988). This inverse relationship is not supported for diaspores with a mass less than the mean diaspore mass in the Everglades when buoyancy is used as the measure of dispersal. Although buoyancy is utilized as a measure of dispersibility in the Venable and Brown (1988) seed model, it is not a full measure of dispersibility, and another measure could give different results.

In addition to the biotic traits discussed above, there are several important abiotic factors to be considered. Among abiotic factors, water flow is central to hydrochorous dispersal. In hydrochory, hydroperiod and wind are the primary drivers. Wind is responsible for both vector components (direction and velocity) across the water surface (so-called 'fetch 
dynamics'). Diaspores with a smaller mass, according to the Law of Momentum $\left(\mathrm{m}_{1} \mathrm{v}_{1}=\mathrm{m}_{2} \mathrm{v}_{2}\right)$, move faster across the water surface than diaspores with larger mass under the same environmental conditions (Table 7).

In surface flow measurements made along the east side of the Shark River Slough Tram Road, the average surface velocity (between mid-June to mid-August 2003 from sloughs between adjacent sawgrass patches) was $3 \mathrm{~cm} / \mathrm{sec}$. At this rate, unimpeded seeds of sawgrass could move $7.8 \mathrm{~km} /$ day (Table 7). There is only one caveat: the word 'unimpeded' is of major concern in the Everglades. With the anthropogenic manipulations in the last century, most of the Everglades north of the Tamiami Trail lacks free-flowing and storm-pulsing water movement (Science Coordination Team 2003). Because of the reduced flow, dense masses of sawgrass and cattail have developed where the movement of floating seeds has been impeded. These new environmental disturbances, added to the functional traits filter, have undoubtedly changed the filtrate of functional dispersal traits (Fig. 1). The removal of these impediments is fundamental to the restoration of conditions to reestablish greater surface water seed movement in the Everglades. Anthropogenic changes in hydrology have also reduced the waterfowl community by altering the seasonality of water levels - too little or too much water-which most likely has reduced the zoochorous back up as an alternative dispersal method.

\section{CONCLUSIONS}

Community assembly of diaspore dispersal in the Everglades is primarily a consequence of historical events and processes which have acted upon the historical plant species pool South Florida and have driven this species pool with its functional traits to its present state. For all species, functional dispersal traits are subsets of morphological traits and reproductive phenology traits. These traits are a collective expression of community dispersal assembly. 
Four suites of functional dispersal traits were identified by factor analysis: small diaspore size relating to anemochory and zoochory; diaspore size and fleshy diaspores relating to zoochory; good buoyancy relating to hydrochory and zoochory; and dispersal-enabling appendages supporting hydrochory and zoochory. Diaspore buoyancy duration graphs were used to reveal species clusters. But buoyancy data analyses did not support Venable and Brown's (1988) model that hypothesized greater dispersibility for diaspores of low mass.

The following assembly patterns, or trends, can be stated for diaspore dispersal in the Everglades, according to the trait-environment paradigm for community assembly:

(1) Reproductive phenology is timed to mesh with the wet-dry season. For most species, the onset of flowering precedes the rainy season and peaks in the early rainy season. Dispersal lags behind flowering by about two months and peaks in July and August.

(2) Among life forms, seasonal flowering and dispersal variations occur as follows: peak flowering for the dispersal of graminoids is from May to October and from July to October; peak flowering for the dispersal of forbs is from April to July and from May to September; peak flowering for the dispersal of temperate woody plants is from April to July and from August to December and; peak flowering for the dispersal of tropical woody plants is from April to June and from August to January.

(3) Morphological traits found to aid the dispersal syndromes are: snagging appendages which enhance hydrochory, endozoochory, and epizoochory; diaspores with small masses which enhance anemochory, epizoochory, and endozoochory; and buoyancy which enhances hydrochory, endozoochory, and epizoochory. More specifically, the effect of functional traits directing each dispersal syndrome can be stated as follows: hydrochory is enhanced by buoyancy and snagging; anemochory is enhanced by small diaspore size and a pappus or winged diaspore; epizoochory is enhanced by small diaspore size and snagging coupled with 
buoyancy; and endozoochory is enhanced by snagging, along with buoyancy, and a fleshy seed covering.

This study has sought to analyze the significant amount of functional trait variation that supports modes of diaspore dispersal in the Everglades. Several anthropogenic barriers, however, impede fundamental hydrochorous dispersal. These barriers include levees, roads causing restricted water flow, dense masses of vegetation resulting from flow restriction, and excessive drainage resulting in shortened hydroperiods setting up deep-burn conditions for vegetation. Perhaps, one of the most relevant restoration efforts toward improving hydrochorous dispersal would be to allow storm surges to occur, in order to achieve the necessary scouring and fragmentation of existing dense vegetation masses. Without these surges only zoochory is regularly available for colonizing distant areas. 


\section{LITERATURE CITED}

Baker, H. G. 1972. Seed weight in relation to environmental conditions in California. Ecology 53: 997-1010.

Casanova, M. T. and M. A. Brock. 2000. How do depth, duration and frequency of flooding influence the establishment of wetland plant communities? Plant Ecology 147:237-250.

Correll, D. S. and H. B. Correll. 1972. Aquatic and Wetland Plants of Southwestern United States. Water Pollution Control, Research Series. Environ. Protection Agency. Washington, D. C. 1777 pp.

Correll, D. S. and H. B. Correll. 1982. Flora of the Bahamas Archipelago. A.R. Ganter Verlag KG, FL-9490 Verduz.

DeAngelis, D. L. and P. S. White. 1994. Ecosystems as products of spatially and temporally varying driving forces, ecological processes, and landscapes: a theoretical perspective. Pgs. 9-27 in: Everglades: the Ecosystem and its Restoration, S. M. Davis and J. C. Ogden (eds.). St. Lucie Press. Boca Raton, FL

Diaz, S., M. Cabido, and F. Casanoves. 1999. Functional implications of trait-environment linkages in plant communities. Pgs. 338-362 in: W. Weiher and P. Keddy (Editors) Ecological Assembly Rules, perspectives, advances, retreats. Cambridge Univ. Press, Cambridge, UK.

Dominguez, C. A., L. E. Eguiarte, J. Nunez, and R. Dirzo. 1998. Flower morphometry of Rhizophora mangle (Rhizophoraceae): geographical variation in Mexican populations. American Journal of Botany 85:637-643.

Drake, J. A., C. R. Zimmermann, T. Purucker, and C. Rojo. 1999. On the nature of the assembly trajectory. pgs.. 233-250 in: W. Weiher and P. Keddy (eds.) Ecological Assembly Rules, perspectives, advances, retreats. Cambridge Univ. Press, Cambridge, UK.

Fairbanks, D. H. K. 2000. Physio-climatic classification of South Africa's woodland biome. Plant Ecology 14:71-89.

Fassett, N. C. 1968. A Manual of Aquatic Plants. University of Wisconsin Press. Madison, WI. $405 \mathrm{pp}$.

Fenner, M. 1985. Seed Ecology. Outline Studies in Ecology. Chapman \& Hall. New York, NY. 151 pp.

Fenner, M. and K. Thompson 2005. The Ecology of Seeds. Cambridge University Press. Cambridge, U.K. 250 pp.

Gleason, P. J. 1974. The environmental significance of Holocene sediments from the Everglades and saline tidal plain. pgs. 287-341 in: Environments of South Florida: Present and Past. P.J. Gleason (ed.). Memoir 2. Miami Geological Society. Miami, FL. 
Gleason, P. and P. Stone. 1994. Age, origin, and landscape evolution of the Everglades peatland. Pgs. 149-198 in: Everglades: the Ecosystem and its Restoration, S. Davis and J. Ogden (eds.). St. Lucie Press. Boca Raton, FL.

Godfrey, R. K. and J. W. Wooten. 1979. Aquatic and Wetland Plants of Southeastern United States: Monocotyledons. University Georgia Press. Athens, GA. 712 pp.

Godfrey, R. K. and J. W. Wooten. 1981. Aquatic and Wetland Plants of Southeastern United States: Dicotyledons. University Georgia Press. Athens, GA. 932 pp.

Gordon, E. 1998. Seed characteristics of plant species from riverine wetlands of Venezuela. Aquatic Botany 60:417-431.

Harper, J. L., P. H. Lovell, and K. G. Moore. 1970. The shapes and sizes of seeds. Annual Review of Ecology and Systematics 1:327-356.

Henry, J. A., K. M. Portier, and J. Coyne. 1994. The Climate and Weather of Florida. Pineapple Press, Inc. Sarasota, FL. 279 pp.

Hofstetter, R. H. and L. E. Hilsenbeck. 1980. Appendix I-B. List of soil-sediment types present in the East Everglades. In: Vegetational studies of the East Everglades. Final Report to Metro. Dade County, Miami, Florida. Part of the East Everglades Resources Planning Project. Photocopy. 109 pp.

Howe, H.F. and J. Smallwood. 1982. Ecology of seed dispersal. Annual Review of Ecology and Systematics 13:201-228.

Jakobsson, A. and O. Eriksson. 2000. A comparative study of seed number, seed size, seedling size, and recruitment in grassland plants. Oikos 88:494-502.

Johnson, S. 2004. Effects of water level and phosphorous enrichment on seedling emergence from marsh seed banks collected from northern Belize. Aquatic Botany 79:311-323.

Keddy, P. and E. Weiher. 1999. Introduction: The scope and goals of research on assembly rules. pgs. 1-20. In: W. Weiher and P. Keddy (eds.) Ecological Assembly Rules, Perspectives, Advances, Retreats. Cambridge Univ. Press, Cambridge, UK.

Krzanowiski, W. 2007. Statistical Primer and Techniques in Scientific and Social Research. Oxford Univ. Press, NY. 241 pp.

Leck, M. A. and W. Schutz. 2005. Regeneration of Cyperaceae, with particular reference to seed ecology and seed banks. Perspectives in Plant Ecology, Evolution and Systematics 7:95-133.

Keeley, J. E. and P. J. van Mantgem. 2008. Seedling communities, pgs. 255 - 273. In: M. A. Leck, V. T. Parker, and R. L. Simpson (eds.) Seedling Ecology and Evolution. Cambridge Univ. Press, Cambridge, UK. 
Long, R. W. and O. Lakela. 1971. A Flora of Tropical Florida: a Manual of the Seed Plants and Ferns of Southern Peninsular Florida. University of Miami Press. Coral Gables, FL. 962 pp.

Lopez, O. R. 2001. Seed flotation and postflooding germination in tropical terra firme and seasonally flooded forest species. Functional Ecology 15:763-771.

McGill, B. J., B. J. Enquist, E. Weiher, and M. Westoby. 2006. Rebuilding community ecology from functional traits. TREE 21:178-185.

Minchinton, T. E. 2006. Rafting on wrack as a mode of dispersal for plants in coastal marshes. Aquatic Botany 84:372-376.

Olmsted, I. and T. V. Armentano. 1997. Vegetation of Shark Slough, Everglades National Park. SFNRC Technical Report 97-001. S. Florida Natural Resource Center, Everglades National Park, Homestead, FL. 41 pp.

Ross, M. S., P. L. Ruiz, D. L. Reed, K. Jayachandran, C. L. Coultas, J. P. Sah, and M. T. Lewen. 2001. Assessment of Marsh Vegetation Responses to Hydrological Restoration in Shark Slough, Everglades National Park. Final Report to Everglades National Park and Florida International University. Miami, FL Photocopy. 48 pp.

Science Coordination Team. 2003. The Role of Flow in the Everglades Ridge and Slough Landscape. South Florida Ecosystem Restoration Working Group. Florida International University. Miami, FL.

South Florida Ecosystem Task Force. 2000. Coordination Success: Strategy for Restoration of the South Florida Ecosystems. Electronic Publication as CD. Florida International University. Miami, FL.

SPSS. 1997. Systat 7.0: Statistics. SPSS, Inc. Chicago, IL. 751 pp.

Strahler, A. and A. Strahler. 1998. Introductory Physical Geography, Second Edition. J. Wiley and Sons, Inc. 567 pp.

Tabb, D. C. 1963. A Summary of Existing Information of the Freshwater, Brackish-water, and Marine Ecology of the Florida Everglades Region in Relation to Freshwater Needs of Everglades National Park. The Marine Laboratory, Institute of Marine Science. University of Miami. Coral Gables, FL 152 pp.

Tiffney, B. H. 1984. Seed size, dispersal syndromes and the rise of angiosperms: evidence and hypothesis. Annals Missouri Botanical Garden 71(2):551-576.

USDA. 1999. Soil Taxonomy: A Basic System of Soil Classification for Making and Interpreting Soil Surveys, Second Edition. Publication \#436. U. S. Department of Agriculture.

van der Pijl, L. 1982. Principles of Dispersal in Higher Plants, Third Edition. Springer-Verlag. NY, NY. 215 pp. 
van der Valk, A. G. and T. R. Rosburg. 1997. Seed bank composition along a phosphorus gradient in the Northern Florida Everglades. Wetlands 17:228-236.

Venable, D. L. and J. S. Brown. 1988. The selective interactions of dispersal, dormancy, and seed size as adaptations for reducing risk in variable environments. American Naturalist 131:360-384.

Vivian-Smith, G. and E. W. Stiles. 1994. Dispersal of salt marsh seeds on the feet and feathers of waterfowl. Wetlands 14:316-319

Wongsriphuek, C., B. D. Dugger, and A. M. Bartuszevige. 2008. Dispersal of wetland seeds by mallards: influence of gut passage on recovery, retention, and germination. Wetlands 28:290-299.

Wunderlin, R. P. and B. F. Hansen. 2003. Guide to the Vascular Plants of Florida, Second Edition. University Press of Fla. Gainesville, FL. 787 pp. 
Table 1. Summary of reproductive phenology data for plant life form categories by month at Shark River Slough ENP. See Appendix B for values by species. F = flowering, $\mathrm{D}=$ dispersing.

\begin{tabular}{|c|c|c|c|c|c|c|c|c|c|c|c|c|}
\hline Species Category & $\mathbf{J}$ & $\mathbf{F}$ & $\mathbf{M}$ & $\mathbf{A}$ & M & $\mathbf{J}$ & $\mathbf{J}$ & $\mathbf{A}$ & $\mathbf{S}$ & $\mathbf{O}$ & $\mathbf{N}$ & $\mathbf{D}$ \\
\hline $\begin{array}{l}\text { Graminoid Total } \\
(\mathrm{n}=14 ; \mathrm{F} / \mathrm{D})\end{array}$ & $\begin{array}{l}4 \\
5\end{array}$ & $\begin{array}{l}3 \\
3\end{array}$ & $\begin{array}{l}6 \\
5\end{array}$ & $\begin{array}{l}9 \\
5\end{array}$ & $\begin{array}{c}12 \\
5\end{array}$ & $\begin{array}{c}12 \\
9\end{array}$ & $\begin{array}{l}12 \\
12\end{array}$ & $\begin{array}{l}12 \\
12\end{array}$ & $\begin{array}{l}12 \\
12\end{array}$ & $\begin{array}{l}11 \\
13\end{array}$ & $\begin{array}{l}10 \\
11\end{array}$ & $\begin{array}{l}7 \\
9\end{array}$ \\
\hline $\begin{array}{l}\text { Forb Total } \\
(\mathrm{n}=27 ; \mathrm{F} / \mathrm{D})\end{array}$ & $\begin{array}{l}16 \\
14\end{array}$ & $\begin{array}{l}11 \\
10\end{array}$ & $\begin{array}{l}17 \\
11\end{array}$ & $\begin{array}{l}20 \\
13\end{array}$ & $\begin{array}{l}21 \\
18\end{array}$ & $\begin{array}{l}23 \\
21\end{array}$ & $\begin{array}{l}23 \\
22\end{array}$ & $\begin{array}{l}18 \\
21\end{array}$ & $\begin{array}{l}15 \\
19\end{array}$ & $\begin{array}{l}15 \\
15\end{array}$ & $\begin{array}{l}15 \\
14\end{array}$ & $\begin{array}{l}15 \\
14\end{array}$ \\
\hline $\begin{array}{l}\text { Woody Temperate } \\
\text { Total }(n=7 ; \mathbf{F} / \mathbf{D})\end{array}$ & $\begin{array}{l}4 \\
2\end{array}$ & $\begin{array}{l}3 \\
2\end{array}$ & $\begin{array}{l}3 \\
2\end{array}$ & $\begin{array}{l}6 \\
2\end{array}$ & $\begin{array}{l}6 \\
1\end{array}$ & $\begin{array}{l}5 \\
1\end{array}$ & $\begin{array}{l}4 \\
3\end{array}$ & $\begin{array}{l}3 \\
4\end{array}$ & $\begin{array}{l}1 \\
5\end{array}$ & $\begin{array}{l}1 \\
4\end{array}$ & $\begin{array}{l}1 \\
5\end{array}$ & $\begin{array}{l}1 \\
4\end{array}$ \\
\hline $\begin{array}{c}\text { Woody Tropical } \\
\text { Total }(\mathrm{n}=3 ; \text { F/D) }\end{array}$ & $\begin{array}{l}2 \\
2\end{array}$ & $\begin{array}{l}2 \\
1\end{array}$ & $\begin{array}{l}2 \\
1\end{array}$ & $\begin{array}{l}3 \\
1\end{array}$ & $\begin{array}{l}3 \\
1\end{array}$ & $\begin{array}{l}3 \\
1\end{array}$ & $\begin{array}{l}2 \\
1\end{array}$ & $\begin{array}{l}1 \\
2\end{array}$ & $\begin{array}{l}1 \\
2\end{array}$ & $\begin{array}{l}1 \\
1\end{array}$ & $\begin{array}{l}1 \\
1\end{array}$ & $\begin{array}{l}1 \\
2\end{array}$ \\
\hline $\begin{array}{l}\text { Total All Species } \\
\quad(n=51 ; \text { F/D })\end{array}$ & $\begin{array}{l}26 \\
25\end{array}$ & $\begin{array}{l}19 \\
16\end{array}$ & $\begin{array}{l}28 \\
19\end{array}$ & $\begin{array}{l}38 \\
21\end{array}$ & $\begin{array}{l}42 \\
25\end{array}$ & $\begin{array}{l}43 \\
32\end{array}$ & $\begin{array}{l}41 \\
38\end{array}$ & $\begin{array}{l}35 \\
39\end{array}$ & $\begin{array}{l}29 \\
36\end{array}$ & $\begin{array}{l}28 \\
33\end{array}$ & $\begin{array}{l}27 \\
31\end{array}$ & $\begin{array}{l}24 \\
29\end{array}$ \\
\hline
\end{tabular}


Table 2. Seed and diaspore functional dispersal trait means for selected plant categories at Shark River Slough, ENP. See Appendix C for values by species.

\begin{tabular}{|c|c|c|c|c|c|c|}
\hline Categories of Species & $\begin{array}{c}\text { Mean } \\
\text { Seed } \\
\text { Mass } \\
\text { (mg S.E.) }\end{array}$ & \begin{tabular}{|c} 
Mean \\
Diasp. \\
Mass \\
(mg S.E.)
\end{tabular} & $\begin{array}{c}\text { Mean } \\
\text { Seed } \\
\text { Len. } \\
\text { (mm S.E.) }\end{array}$ & $\begin{array}{c}\text { Mean } \\
\text { Diasp. } \\
\text { Len. } \\
\text { (mm S.E.) }\end{array}$ & \begin{tabular}{|c|} 
Mean \\
Seed \\
Buoy. \\
(FD $_{50}$ S.E. $)$
\end{tabular} & $\begin{array}{c}\text { Mean } \\
\text { Diasp. } \\
\text { Buoy. } \\
\text { (FD } \\
\text { S.E.) }\end{array}$ \\
\hline $\begin{array}{l}\text { Graminoids } \\
\quad(n=14)\end{array}$ & $\begin{array}{r}1.7 \\
+0.9\end{array}$ & $\begin{array}{r}2.1 \\
+1.1\end{array}$ & $\begin{array}{r}3.5 \\
+1.6\end{array}$ & $\begin{array}{r}4.0 \\
+2.0\end{array}$ & $\begin{array}{r}5.4 \\
+2.4\end{array}$ & $\begin{array}{r}7.6 \\
+2.9\end{array}$ \\
\hline $\begin{array}{c}\text { Cyperaceae } \\
(\text { Medians, } n=11)\end{array}$ & 0.9 & 0.9 & 1.5 & 1.4 & 3.0 & 3.0 \\
\hline $\begin{array}{c}\text { Forbs } \\
(n=27)\end{array}$ & $\begin{array}{r}22.0 \\
+13.0\end{array}$ & $\begin{array}{r}74.7 \\
+66.5\end{array}$ & $\begin{array}{r}3.4 \\
+0.6\end{array}$ & $\begin{array}{r}3.5 \\
+0.9\end{array}$ & $\begin{array}{r}15.5 \\
+3.8\end{array}$ & $\begin{array}{r}16.7 \\
+4.0\end{array}$ \\
\hline $\begin{array}{c}\text { Woody Temperate } \\
(\mathrm{n}=7)\end{array}$ & $\begin{array}{r}48.5 \\
+30.7\end{array}$ & $\begin{array}{r}40.5 \\
+29.1\end{array}$ & $\begin{array}{r}5.3 \\
+1.2\end{array}$ & $\begin{array}{r}4.1 \\
+1.2\end{array}$ & $\begin{array}{r}8.6 \\
+5.6\end{array}$ & $\begin{array}{r}11.0 \\
+5.1\end{array}$ \\
\hline $\begin{array}{c}\text { Woody Tropical } \\
(n=3)\end{array}$ & 366.5 & 371 & 15.1 & 62.3 & 30 & 30 \\
\hline $\begin{array}{l}\text { Herbaceous } \\
(n=41)\end{array}$ & $\begin{array}{r}14.0 \\
+7.6\end{array}$ & $\begin{array}{r}44.3 \\
+38.7\end{array}$ & $\begin{array}{r}3.4 \\
+0.7\end{array}$ & $\begin{array}{r}3.7 \\
+0.9\end{array}$ & $\begin{array}{r}10.5 \\
+1.2\end{array}$ & $\begin{array}{r}12.2 \\
+2.5\end{array}$ \\
\hline $\begin{array}{l}\text { Woody } \\
(n=10)\end{array}$ & $\begin{array}{r}128.0 \\
+66.2\end{array}$ & $\begin{array}{r}106.6 \\
\pm 69.8\end{array}$ & $\begin{array}{r}7.7 \\
+1.8\end{array}$ & $\begin{array}{r}23.5 \\
+15.7\end{array}$ & $\begin{array}{r}14.7 \\
+5.5\end{array}$ & $\begin{array}{r}16.7 \\
\pm 4.5\end{array}$ \\
\hline $\begin{array}{c}\text { Total Species } \\
(\mathbf{n}=51)\end{array}$ & $\begin{array}{r}36.3 \\
+15.4\end{array}$ & $\begin{array}{r}54.9 \\
+34.6 \\
\end{array}$ & $\begin{array}{r}4.2 \\
+0.7\end{array}$ & $\begin{array}{r}7.3 \\
+3.0\end{array}$ & $\begin{array}{r}11.4 \\
+2.3 \\
\end{array}$ & $\begin{array}{r}13.4 \\
+2.2 \\
\end{array}$ \\
\hline
\end{tabular}


Table 3. Means for major functional dispersal traits of 51 species by five seasonal dispersal categories in Shark River Slough, ENP. Season 4 had only one species, sneezeweed (Helenium pinnatifidum). Diaspores are seeds plus allied matter.

\begin{tabular}{|c|c|c|c|c|c|}
\hline $\begin{array}{c}\text { Species } \\
\text { Functional } \\
\text { Traits }\end{array}$ & $\begin{array}{l}\text { (1) Early Wet } \\
\text { (MJJA) }\end{array}$ & $\begin{array}{l}\text { (2) Late Wet } \\
\text { (SONDJ) }\end{array}$ & $\begin{array}{c}\text { (3) All Wet } \\
\text { (MJJASONDJ) }\end{array}$ & $\begin{array}{l}\text { (4) Dry } \\
\text { (FMA) }\end{array}$ & (5) All Year \\
\hline $\begin{array}{c}\text { Seed } \\
\text { Mass (mg) }\end{array}$ & $\begin{array}{c}3.3 \\
+22.9 \text { S.E. } \\
2.5 \text { C.V. }\end{array}$ & $\begin{array}{c}48.6 \\
+20.5 \text { S.E. } \\
\text { 1.6 C.V. }\end{array}$ & $\begin{array}{c}2.4 \\
+2.2 \text { S.E. } \\
2.2 \text { C.V. }\end{array}$ & -- & $\begin{array}{c}48.6 \\
+45.3 \text { S.E. } \\
\text { 3.2 C.V. }\end{array}$ \\
\hline $\begin{array}{c}\text { Diaspore } \\
\text { Mass (mg) }\end{array}$ & $\begin{array}{c}3.8 \\
+1.3 \text { S.E. } \\
0.9 \text { C.V. }\end{array}$ & $\begin{array}{c}50.7 \\
+33.9 \text { S.E. } \\
2.2 \text { C.V. }\end{array}$ & $\begin{array}{c}174.2 \\
+171.7 \text { S.E. } \\
\text { 2.6 C.V. }\end{array}$ & -- & $\begin{array}{c}10.0 \\
+4.6 \text { S.E. } \\
1.4 \text { C.V. }\end{array}$ \\
\hline $\begin{array}{c}\text { Seed } \\
\text { Length }(\mathrm{mm})\end{array}$ & $\begin{array}{c}5.6 \\
+1.6 \text { S.E. } \\
0.9 \text { C.V. }\end{array}$ & $\begin{array}{c}5.3 \\
+1.5 \text { S.E. } \\
1.1 \text { C.V. }\end{array}$ & $\begin{array}{c}1.7 \\
+0.3 \mathrm{~S} . \mathrm{E} . \\
0.5 \mathrm{C} . \mathrm{V}\end{array}$ & -- & $\begin{array}{c}3.6 \\
+1.2 \mathrm{~S} . \mathrm{E} . \\
1.1 \mathrm{C} . \mathrm{V} .\end{array}$ \\
\hline $\begin{array}{c}\text { Diaspore } \\
\text { Length }(\mathrm{mm})\end{array}$ & $\begin{array}{c}16.3 \\
\pm 12.0 \text { S.E. } \\
2.1 \text { C.V. }\end{array}$ & $\begin{array}{c}6.7 \\
+2.4 \text { S.E. } \\
1.3 \text { C.V. }\end{array}$ & $\begin{array}{c}1.9 \\
+0.6 \text { S.E. } \\
0.6 \text { C.V. }\end{array}$ & -- & $\begin{array}{c}2.6 \\
\pm 0.9 \text { S.E. } \\
1.0 \text { C.V. }\end{array}$ \\
\hline $\begin{array}{c}\text { Seed } \\
\text { Buoyancy } \\
\text { (FD } 50 \text { Days) }\end{array}$ & $\begin{array}{c}18.8 \\
+5.1 \text { S.E. } \\
0.7 \text { C.V. }\end{array}$ & $\begin{array}{c}8.8 \\
+3.7 \text { S.E. } \\
1.5 \text { C.V. }\end{array}$ & $\begin{array}{c}9.3 \\
+7.0 \text { S.E. } \\
1.5 \text { C.V. }\end{array}$ & -- & $\begin{array}{c}10.9 \\
+3.9 \text { S.E. } \\
1.1 \text { C.V. }\end{array}$ \\
\hline $\begin{array}{c}\text { Diaspore } \\
\text { Buoyancy } \\
\text { (FD } 50 \text { Days) }\end{array}$ & $\begin{array}{c}20.4 \\
+4.6 \text { S.E. } \\
0.6 \text { C.V. }\end{array}$ & $\begin{array}{c}11.2 \\
+3.7 \text { S.E. } \\
1.2 \text { C.V. }\end{array}$ & $\begin{array}{c}11.0 \\
+6.0 \text { S.E. } \\
1.3 \text { C.V. }\end{array}$ & -- & $\begin{array}{c}12.8 \\
+4.0 \text { S.E. } \\
1.0 \text { C.V. }\end{array}$ \\
\hline
\end{tabular}


Table 4. The factor scores generated from principle component analysis of 14 functional traits for 51 species of flowering plants in Shark River Slough, ENP. Values of 0.40 (absolute value) or more (boxed) obtained in the factor loadings are considered strongly related and discussed in the text. These factor scores are plotted in Figure 5 to determine any trait clustering.

\begin{tabular}{lcccc}
\hline \multicolumn{1}{c}{ Variables } & \multicolumn{3}{c}{ Factor } & $\mathbf{3}$ \\
\hline 1. Appendages can snag & $\mathbf{1}$ & $\mathbf{2}$ & 0.830 \\
2. Appendages enhance buoyancy & 0.741 & -0.029 & -0.274 & -0.074 \\
3. Pappus present & 0.644 & -0.076 & -0.055 \\
4. Diaspore Buoyant & -0.413 & 0.635 & 0.234 \\
5. Buoyant seeds & 0.131 & 0.718 & -0.001 \\
6. Surface feeding possible & -0.004 & 0.698 & -0.359 \\
7. Buoyant fruit & 0.148 & 0.556 & 0.166 \\
8. Seed Length & 0.099 & 0.237 & 0.618 \\
9. Seed Mass & -0.085 & 0.088 & 0.602 \\
10. Mud clinging possible & 0.339 & 0.142 & -0.580 \\
11. Fleshy fruit covering & -0.170 & -0.196 & 0.466 \\
12. Culm feeding possible & -0.132 & 0.340 & -0.040 \\
13. Fruit winged & -0.060 & 0.055 & -0.128 \\
14. Diaspore mass & -0.175 & -0.369 & 0.161 \\
\hline & & & \\
Variance explained by rotated components & 2.075 & 2.173 & 1.560 \\
Percent of Common Variance Explained & 35.7 & 37.4 & 26.9 \\
\hline
\end{tabular}


Table 5. Summary of functional dispersal trait suites. Factor analysis was used to compute factor scores from functional traits of species (Table 4). The factor scores were then plotted and related clusters of traits identified (Fig. 5). Suites of related functional traits from factor loadings 1 x 2 are labeled (see Table 4, Fig. 5). Results of factor loading 1 × 3 are given only for comparison. Suite "A" is composed of traits related to small diaspore mass. Suite "B" is composed of traits related by buoyant diaspores. Suite "C" is composed of traits related by appendage features. Suite "D" is composed of traits related by large diaspores. Traits "E" and "F" are solitary. The four columns at right are ecological dispersal syndromes and " $\mathrm{X}$ " is marked if the trait could be a member of the syndrome.

\begin{tabular}{|c|c|c|c|c|c|c|c|}
\hline \multirow[t]{2}{*}{$\begin{array}{l}\text { Functional } \\
\text { Dispersal Trait } \\
\text { In Species }\end{array}$} & \multicolumn{2}{|c|}{$\begin{array}{c}\text { Clusters } \\
\text { Based on } \\
\text { Plot of } \\
\text { Factor } \\
\text { Scores } \\
\end{array}$} & \multirow[t]{2}{*}{$\begin{array}{c}\text { Percent } \\
\text { Of all } \\
\text { Species } \\
\text { With } \\
\text { Trait } \\
\end{array}$} & \multirow[t]{2}{*}{$\begin{array}{l}\text { Hydro- } \\
\text { chory }\end{array}$} & \multirow[t]{2}{*}{$\begin{array}{l}\text { Anemo- } \\
\text { chory }\end{array}$} & \multirow[t]{2}{*}{$\begin{array}{l}\text { Epizoo- } \\
\text { chory }\end{array}$} & \multirow[t]{2}{*}{$\begin{array}{c}\text { Endo- } \\
\text { zoochory }\end{array}$} \\
\hline & $1 \times 2$ & $1 \times 3$ & & & & & \\
\hline Culm feeding present & $\mathrm{A}$ & $\mathrm{A}$ & 36 & & & & $\mathrm{x}$ \\
\hline Fruit winged & $\mathrm{A}$ & $\mathrm{A}$ & 6 & & $\mathrm{x}$ & & \\
\hline Seed Mass & $\mathrm{A}$ & $\mathrm{D}$ & - & & $\mathrm{x}$ & $\mathrm{x}$ & $\mathrm{x}$ \\
\hline Seed Length & $\mathrm{A}$ & $\mathrm{D}$ & - & & $\mathrm{x}$ & $\mathrm{x}$ & $\mathrm{x}$ \\
\hline Surface feeding present & B & A & 78 & $\mathrm{x}$ & & & $\mathrm{x}$ \\
\hline Buoyant seeds & $\mathrm{B}$ & $\mathrm{B}$ & 61 & $\mathrm{x}$ & & $\mathrm{x}$ & $\mathrm{x}$ \\
\hline Buoyant fruit & $\mathrm{B}$ & $\mathrm{B}$ & 56 & $\mathrm{x}$ & & & $\mathrm{x}$ \\
\hline Appendages can snag & $\mathrm{C}$ & $\mathrm{C}$ & 33 & $\mathrm{x}$ & & $\mathrm{x}$ & $\mathrm{x}$ \\
\hline $\begin{array}{l}\text { Appendages enhance } \\
\text { buoyancy }\end{array}$ & $\mathrm{C}$ & $\mathrm{C}$ & 37 & $\mathrm{x}$ & & $\mathrm{x}$ & $\mathrm{x}$ \\
\hline Pappus present & $\mathrm{C}$ & $\mathrm{C}$ & 16 & $\mathrm{x}$ & $\mathrm{x}$ & $\mathrm{x}$ & $\mathrm{x}$ \\
\hline Diaspore mass & $\mathrm{D}$ & $\mathrm{A}$ & - & & $\mathrm{x}$ & $\mathrm{x}$ & $\mathrm{x}$ \\
\hline Fleshy fruit covering & $\mathrm{D}$ & $\mathrm{D}$ & 27 & & & & $\mathrm{x}$ \\
\hline Mud clinging possible & $\mathrm{E}$ & $\mathrm{E}$ & 65 & & & $\mathrm{x}$ & \\
\hline Diaspore Buoyancy & $\mathrm{F}$ & $\mathrm{F}$ & - & $\mathrm{x}$ & & $\mathrm{x}$ & $\mathrm{x}$ \\
\hline $\begin{array}{l}\text { Total identified traits in } \\
\text { each dispersal } \\
\text { syndrome }\end{array}$ & - & - & - & 7 & 5 & 9 & 12 \\
\hline
\end{tabular}


Table 6. Summary of functional dispersal traits with enhancing diaspore features.

Environmental factors that can interact with the dispersal syndromes are at right.

\begin{tabular}{|c|c|c|}
\hline $\begin{array}{l}\text { Ecological Dispersal } \\
\text { Syndrome }\end{array}$ & $\begin{array}{l}\text { Enhancing } \\
\text { Functional Traits }\end{array}$ & $\begin{array}{l}\text { Enhancing } \\
\text { Environmental Factors }\end{array}$ \\
\hline Hydrochory & $\begin{array}{l}\text { Buoyancy: seeds, fruits, or } \\
\text { allied appendages. } \\
\text { Dispersal timed to flooding }\end{array}$ & $\begin{array}{l}\text { Wind \& rain: intensity \& } \\
\text { frequency dislodge seeds } \\
\& \text { move along water } \\
\text { surface. } \\
\text { Flooding (hydroperiod) } \\
\text { Current intensity } \\
\text { Storm disturbances: allow } \\
\text { for more distant dispersal. }\end{array}$ \\
\hline Epizoochory & $\begin{array}{l}\text { Hooks/snaggers: on seeds, } \\
\text { fruits, or appendages. } \\
\text { Pappus: when wind- } \\
\text { dispersed diaspore floats it } \\
\text { allows snagging. } \\
\text { Buoyancy: with snagging } \\
\text { allows attachment to } \\
\text { plumage. } \\
\text { Diaspore mass small: } \\
\text { allows for more secure } \\
\text { attachment. } \\
\text { Dispersal timed to seasonal } \\
\text { waterfowl }\end{array}$ & $\begin{array}{l}\text { Mud: mixes with small } \\
\text { seeds \& sticks to feet. } \\
\text { Waterfowl migration: } \\
\text { species and flyways allow } \\
\text { distant dispersal (plumage } \\
\text { snagging most common for } \\
\text { long-distance dispersal; } \\
\text { (food) timing with } \\
\text { migration. }\end{array}$ \\
\hline Endozoochory & $\begin{array}{l}\text { Flesh-covered fruit: attracts } \\
\text { frugivores. } \\
\text { Buoyant diaspore: allows } \\
\text { water surface feeding } \\
\text { Seeds hang high on culm: } \\
\text { allows for culm feeders } \\
\text { (granivores). } \\
\text { Dispersal timed to seasonal } \\
\text { waterfowl }\end{array}$ & $\begin{array}{l}\text { Waterfowl migration: } \\
\text { species and flyways allow } \\
\text { distant dispersal and } \\
\text { dispersal (food) timing } \\
\text { with migration. }\end{array}$ \\
\hline Anemochory & $\begin{array}{l}\text { Winged diaspore: allows } \\
\text { wind movement. } \\
\text { Pappus: comose matter on } \\
\text { diaspore catches wind. } \\
\text { Diaspore mass small }\end{array}$ & $\begin{array}{l}\text { Wind: intensity \& } \\
\text { frequency. }\end{array}$ \\
\hline
\end{tabular}


Table 7. Potential hydrochorous dispersal distance of diaspores with varying masses. The law of momentum $\left(\mathrm{m}_{1} \mathrm{v}_{1}=\mathrm{m}_{2} \mathrm{v}_{2}\right)$ was used with Hibiscus grandiflora as the reference species $\left(\mathrm{m}_{1} \mathrm{v}_{1}\right)$ in computing potential velocity $\left(\mathrm{v}_{2}\right)$ of other taxa from flowering plants of Shark River Slough, ENP. $\mathrm{FD}_{50}=$ the time for $50 \%$ of tested seeds to sink.

\begin{tabular}{lccc} 
& MEAN MASS & VELOCITY & BUOYANCY \\
& (mg/diaspore) & (cm/sec.) & (FD $_{\mathbf{5 0}}$ days) \\
\hline A. By Species: & & & \\
& 1.00 & $24.4^{*}$ & 4 \\
Sagittaria lancifolia & 1.85 & $13.2^{*}$ & 3 \\
Rhynchospora tracyi & 2.71 & $9.0^{*}$ & 12 \\
Cladium jamaicense & $\mathbf{8 . 1 3}$ & $\mathbf{3 . 0}$ & $\mathbf{3}$ \\
Hibiscus grandiflora $\left(\mathbf{m}_{\mathbf{1}} \mathbf{v}_{\mathbf{1}}\right)$ & 13.7 & 1.8 & 30 \\
Rhynchospora inundata & 547.0 & 0.04 & 30 \\
Chrysobalanus icaco & & & \\
& & & \\
\hline B. By Life Form: & 0.84 (median) & $29.0^{*}$ & 3 (median) \\
Gramineae & 3.85 (median) & $6.3^{*}$ & 15 (median) \\
Forbs & 18.39 (median) & 1.3 & 4 (median) \\
Woody Temperate & & &
\end{tabular}

\section{Within A Species: sawgrass} (data from Chapter 4)

$\begin{array}{lrr}\text { Lowest mass to germinate } & 1.1 & 22.2^{*} \\ \text { Largest mass to germinate } & 5.8 & 4.2^{*}\end{array}$

*The viscosity of water and plant stem interference begins to cause water turbulence that slows diaspore movement as the velocity exceeds $3.0 \mathrm{~cm} / \mathrm{sec}$. friction (Leonard et al. 2006). The shape of the diaspore can also influence hydrochory dynamics, so that the higher velocities listed above are not realized. Surface matter, such as dead plant litter, algal mats, and Utricularia spp., also impede the surface movement of materials, i.e., diaspores (Leonard et al 2006). Changes in wind velocity and direction across the water surface (fetch dynamics) also contribute to diaspore velocity. 
The Regional Species Pool Is Composed of Species with Functional Traits (FT) That are Tied to Dispersal, Survivorship, and Reproduction and That Pass Through an Ecological Succession Filter

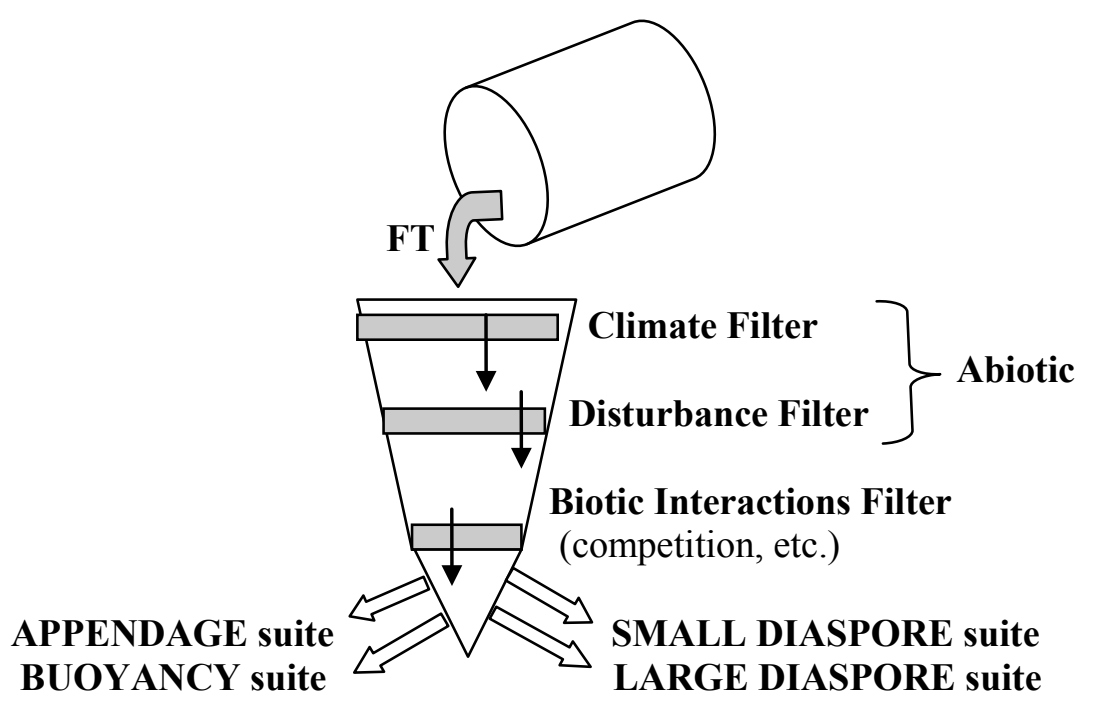

Figure 1. Diagrammatic representation of the ecological filtration process performed on functional traits (FT). The process filtered the FT possessed by the original regional species pool from pre-Everglades south Florida. In the resulting filtrate (below) are those FT, possessed by species, that are appropriate for survival under the present conditions. They may cluster into suites of traits such as those that manage plant dispersal. Community assembly rules describe this as "the imposed means of directing the process of sorting through the regional pool of species' functional traits" (after Diaz et al. 1999). 


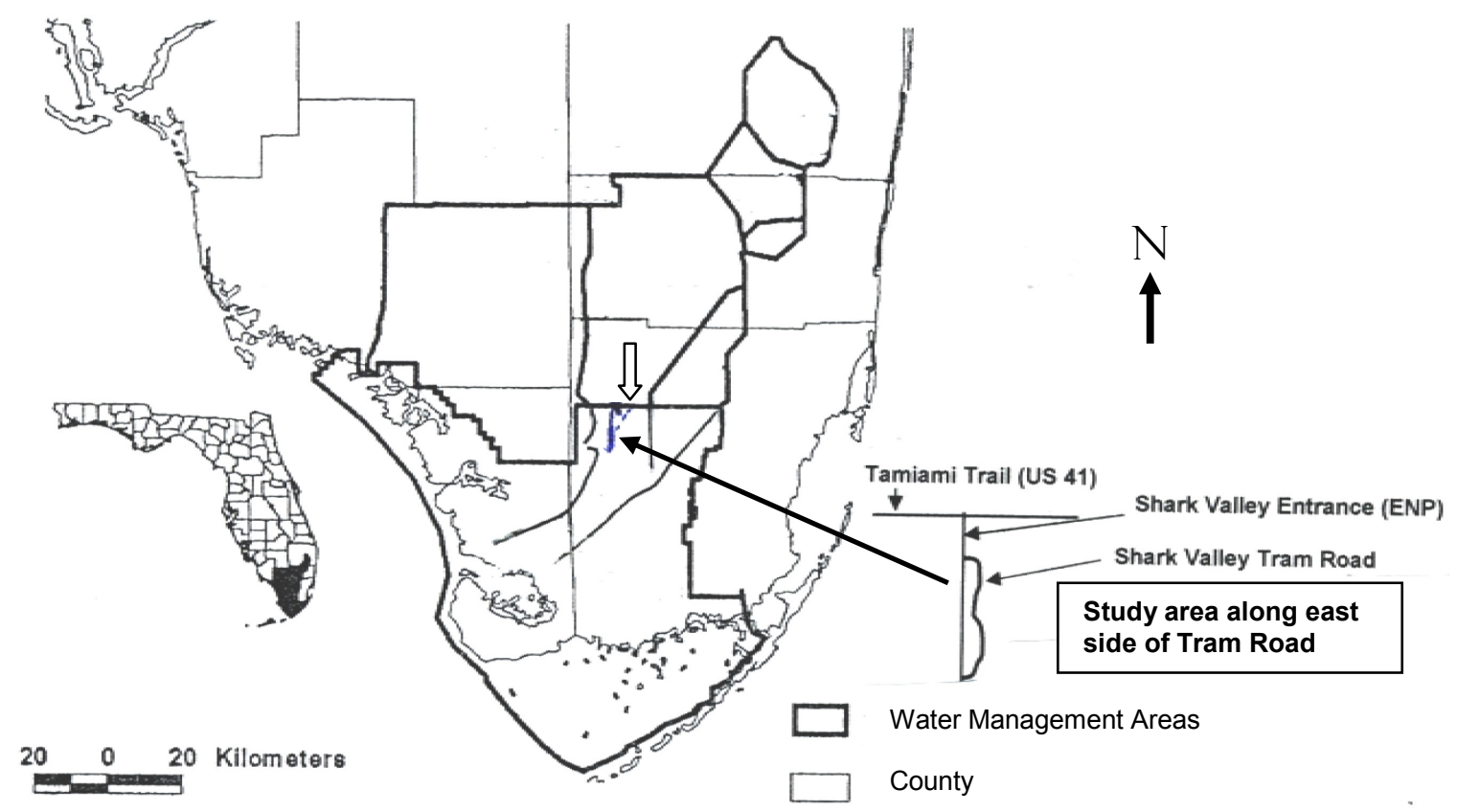

Figure 2. Study location. The area lies south of US 41 in the NW edge of Shark River, Everglades National Park, along the east side of Tram Road. Note that the current flow of Shark River Slough is now more west than was the historical flow (open arrow indicates the historical western edge of the slough). 


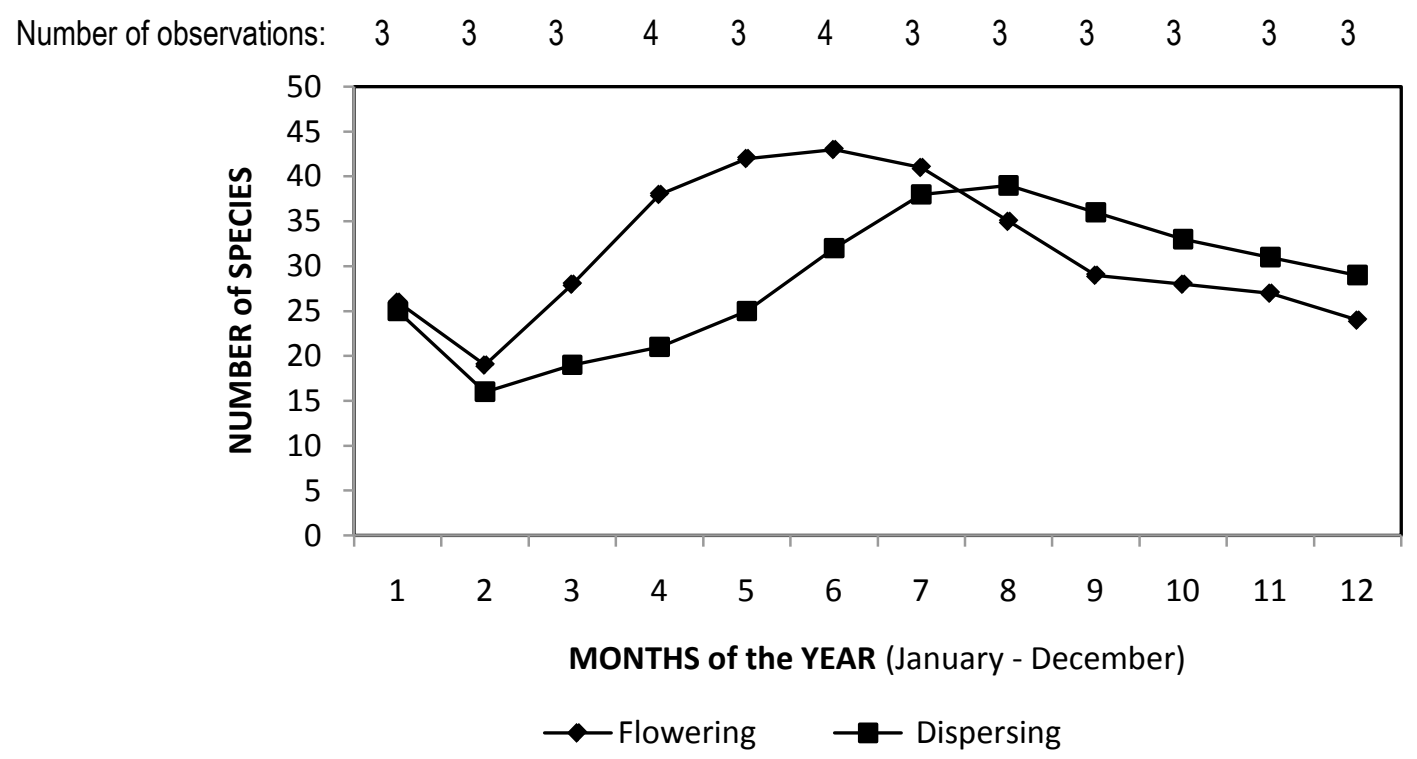

Figure 3. Species flowering and dispersing diaspores by month. Number of visits by month are given along the top. 


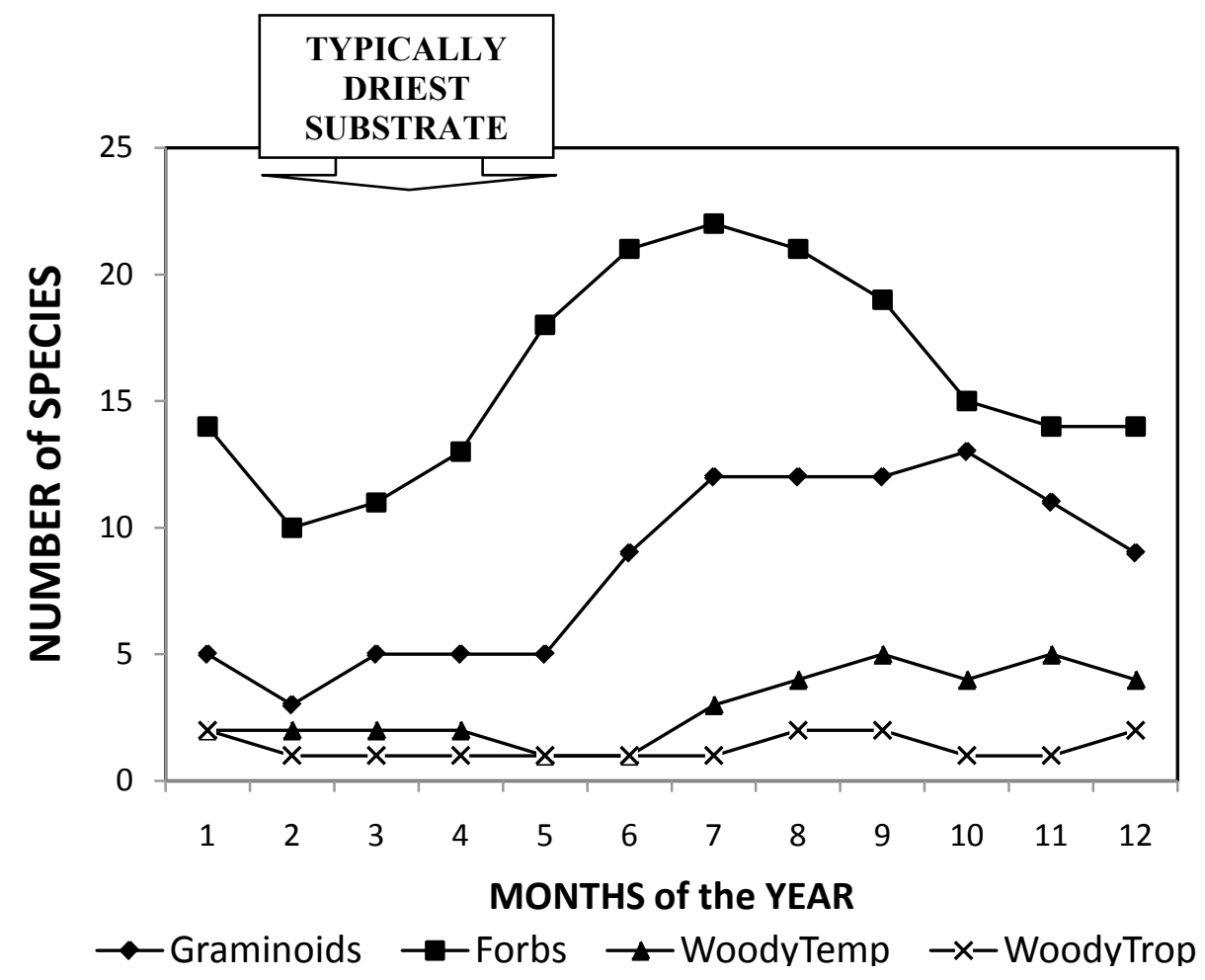

Figure 4. The number of species dispersing diaspores by month in each life form category. $(\mathrm{N}=51)$ 


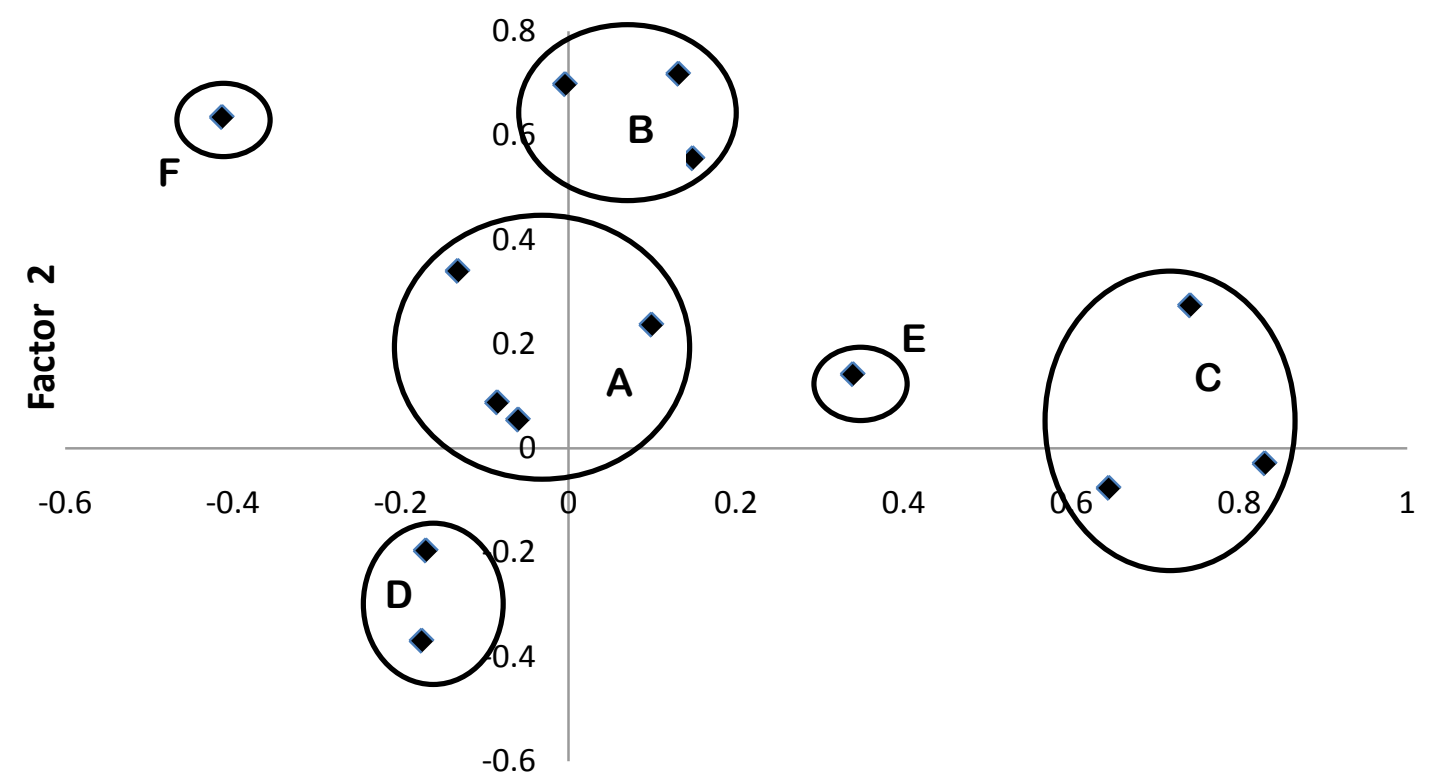

Factor 1

(a)

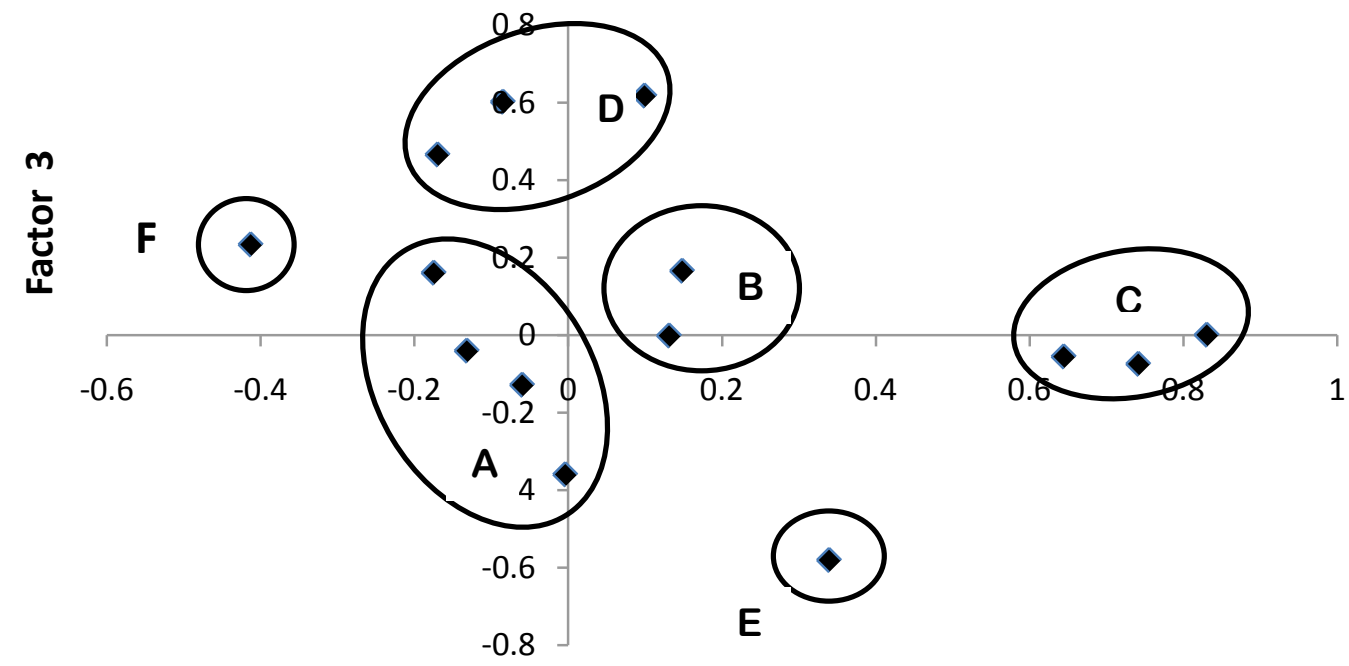

(b)

Factor 1

Figure 5. Spatial pattern of factor loadings. (a) Loadings one and two (1 x 2). (b) Loadings one and three $(1 \times 3)$. Both have encircled functional trait clusters that enhance dispersal. Each dark symbol represents a functional trait. Graph (b) is the ' $z$ ' axis loading. See Table 4 for more details. Only factor loadings 1 x 2 were used for trait clustering analysis (Table 5). 


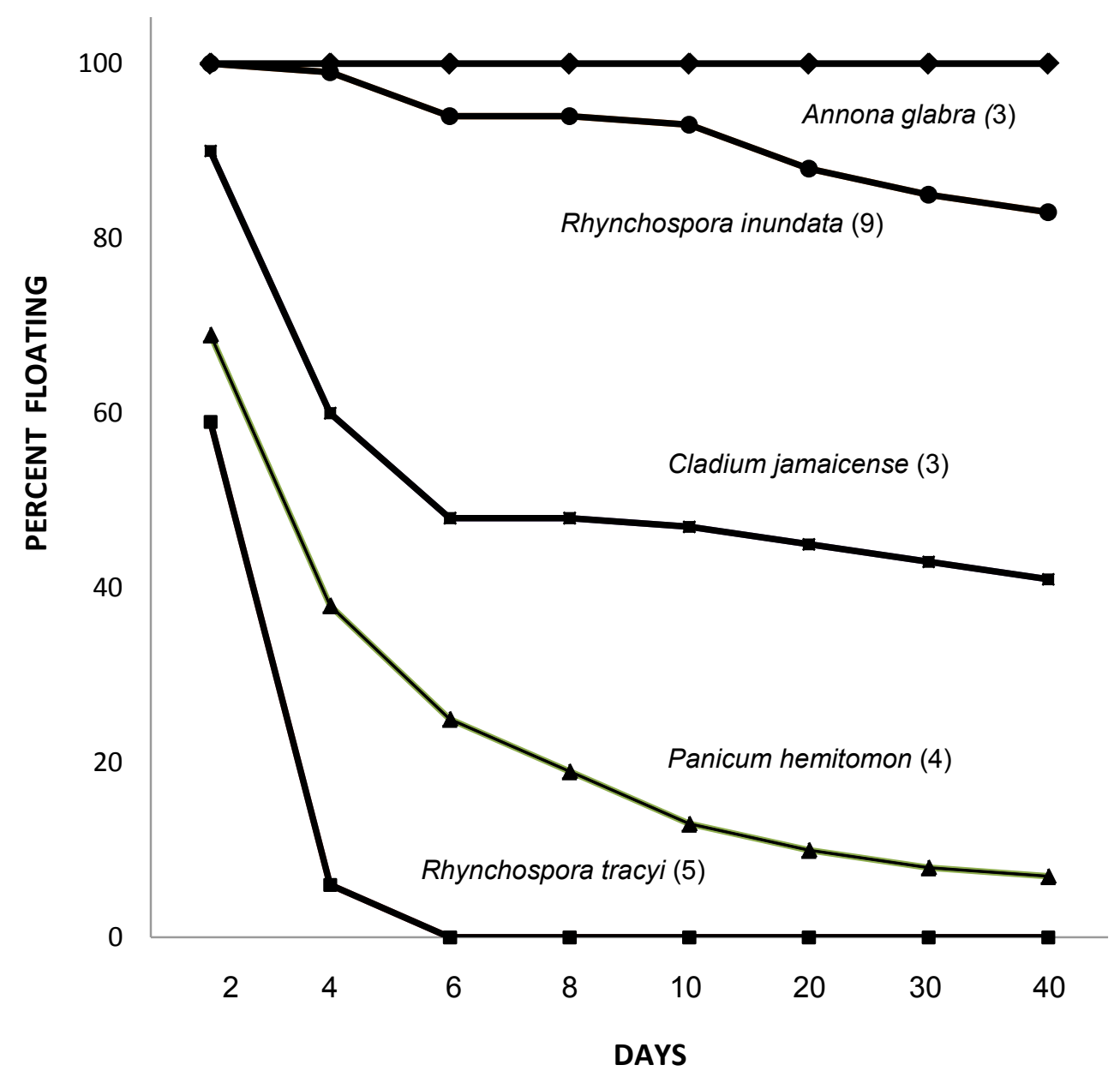

Figure 6. The buoyancy pattern for five representative species of 24 species tested. These five demonstrate the diversity of buoyancy patterns among species. The number of species represented by each of these five patterns is given beside the species names. 


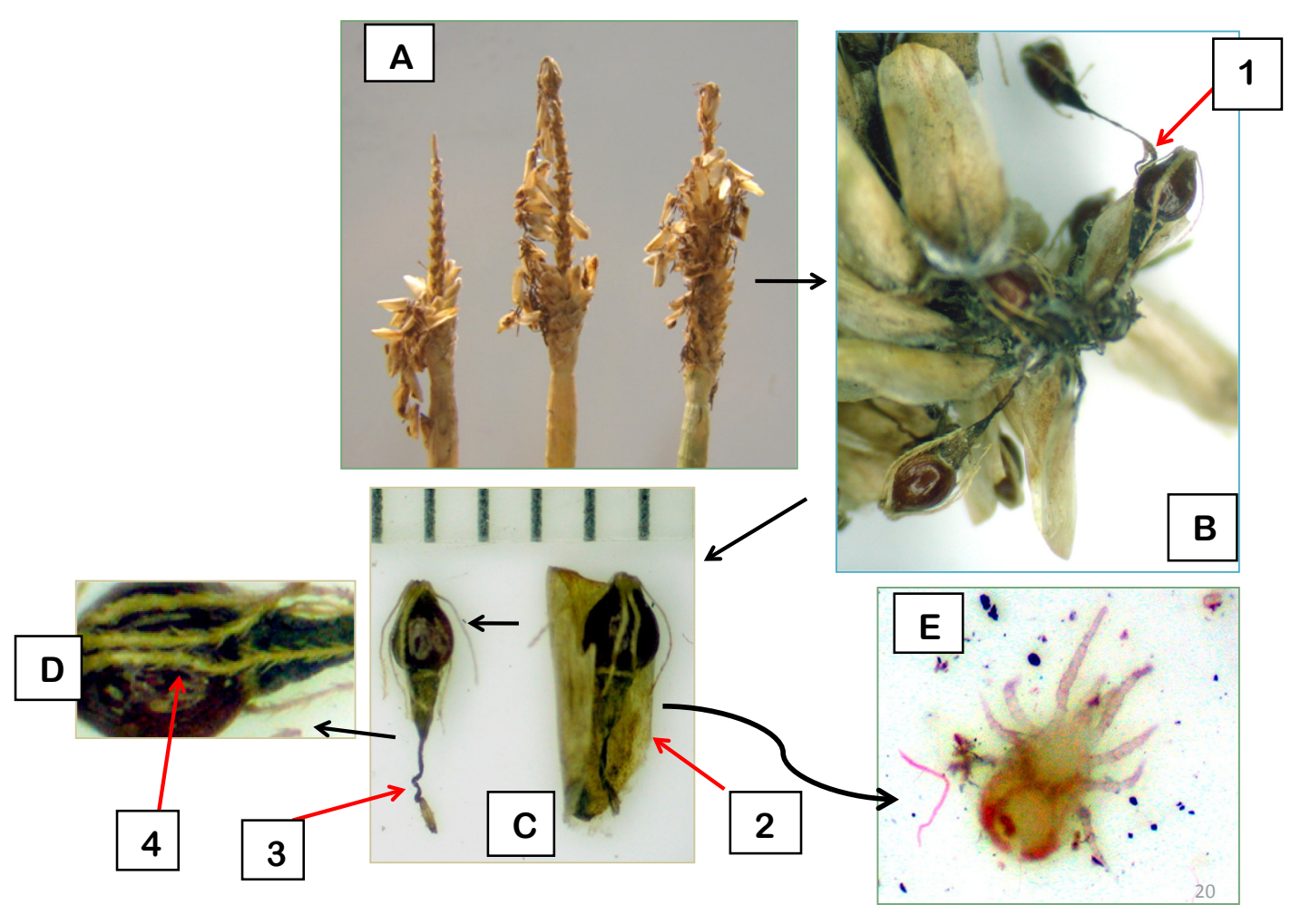

Figure 7. Eleocharis interstincta exhibits the potential for several forms of dispersal. It displays a polydispersal syndrome. Rain dislodges scales from culm spikes (A, B, C-2) which hold the fruit along with six barbed bristles ( 4), a spiral style (C-3), and pubescent stigma (B-1). In addition, a small $(0.33 \times 0.50 \mathrm{~mm})$ spikerush spider mite $(E)$ generates a web that entangles diaspores and scales. The web, and collective snagging of diaspores by stigma (1), scale (2), coiled style (3), barbed bristles (4), leaves a dangling mass at the terminal area of the culm (A), and makes a good display for waterfowl culm eaters, potential snagging in passing waterfowl plumage, or it may fall or be blown to the water surface and float away. The scales and bristles provide buoyancy to an otherwise non-buoyant fruit, and the floating mass makes a good presentation for waterfowl surface and culm feeders. 


\section{CHAPTER III}

\section{SOIL SEEDBANK STRUCTURE AND VEGETATION PATTERNING IN SHARK RIVER SLOUGH, EVERGLADES NATIONAL PARK}

\section{SEEDBANK ABSTRACT}

In the disturbance-prone Everglades ecosystem, successful hydrochorous dispersal is based upon environmental factors, such as storm winds and flow dynamics, as well as upon functional traits that enhance dispersal, such as seed size and buoyancy. This study traces hydrochorous dispersal from maternal plants to seedbanks in sawgrass patches. Soil seedbank structure in sawgrass patch edges was evaluated to determine the role of sawgrass patches as collectors of floating diaspores and as repositories of diaspores held in soil seedbanks.

Germination assay analysis was the primary method utilized to study the sawgrass patch seedbanks. Eleocharis cellulosa represented $60 \%$ of the germinations of 13 identified species. The average diaspore density for the 10 evaluated sites was 486 seeds $/ \mathrm{m}^{2}$. Eleocharis cellulosa, Cladium jamaicense, Sagittaria lancifolia, and Rhynchospora tracyi had the highest site densities, and site occurrence frequencies of $50 \%$ or more. The dominant species in the seedbank were also present in the standing vegetation and with an occurrence frequency range of common to abundant. Seed catching by patch edge and site $\mathrm{x}$ side interaction were significant ( $\mathrm{p} \sqsubseteq 0.05$ ). Soil from the north side of patches had more germinations than did the east and west sides, but variation in germination by side was not statistically significant. More seeds germinated under saturated soil, instead of flooded soil, but germination varied by species.

Seed germination along sawgrass patch edges during dry-down may stabilize patch edges and contribute to the historic ridge and slough pattern. The analysis of sawgrass patch interception of diaspores lends support to seed dispersal as a significant factor in shaping historic vegetation patterning across the Everglades. 
KEY WORDS: seedbank, seed dispersal, diaspore, Everglades, germination assay, hydrochory, functional traits

\section{INTRODUCTION}

Plant communities in the historical Everglades had strong spatial patterning of ridges and sloughs which reflected the direction of water flow (Leonard et al. 2006). The mechanism that produced this north to south patterning likely required differential growth of the plant species involved in generating the pattern (Larsen et al. 2007). The collection and germination of dispersed seeds along sawgrass (Cladium jamaicense Crantz) strand edges may help explain this patterning. The historical patterning has been generally lost because of anthropogenic manipulations of hydrology, resulting in topographic leveling and more homogeneous hydrology (Leonard et al. 2006). Pulses of storm water that both scoured and deposited matter along patch edges, combined with the pervasive sheet flow of water, have been lost. These changes have likely had a negative influence on the process of seed dispersal by water and the accumulation of matter on sawgrass patches (Science Coordination Team 2003; Leonard et al. 2006; Larsen et al. 2009).

Seed dispersal in wetlands is primarily by water, via hydrochory (van der Pijl 1982). In the Everglades flooding occurs by mid to late June in Shark River Slough. Like in grasslands, seeds are held high on the culms of most marsh plants, contributing to successful primary dispersal (Chambers and MacMahon 1994; See also Chapter 2) during the South Florida rainy season storms, from mid May to November. The vegetation in the Everglades is a mosaic of plant patches whose pattern is constantly altered by disturbances such as fire, flood, drought, and severe storms (Wade et al. 1980; DeAngelis and White 1994; Gunderson 1994). While topography dictates the hydroperiod length, it also determines the type of plant community being formed (Goodrick 1974; Gerritsen and Greening 1989; Deuver et al. 1994; Casanova and Brock 2000). The variation in disturbances, topography, and plant patch 
pattern should provide for many opportunities for floating seeds to be caught. The present study addresses two questions: 1) Are floating seeds caught differentially along sawgrass (Cladium jamaicense) patch sides and edges? 2) Do seedbanks in the southern Everglades differ significantly from those in the northern Everglades?

Seeds dispersed by hydrochory should ultimately be stopped along plant patch edges or among floating matter (wrack) that ultimately becomes entangled with plant edges (Michinton 2006). Some of these seeds likely become part of the soil seedbank along sawgrass patches, so that an analysis of seedbanks here should be a measure of recent and past patch seed catching. The term 'diaspore', which includes seed and allied matter, is used throughout the balance of this study as a more appropriate morphological term than 'seed.'

The nature of the seedbank is correlated with other aspects of plant life history and is an important component of ecosystems with disturbance, such as the Everglades (Parker and Kelly 1989). Seedbanks in these disturbed wetlands typically hold more diaspores and are usually a better species match with standing vegetation than those in less disturbed wetlands (Chang et al. 2001; Chambers and MacMahon 1994). In addition, seedbanks of disturbed wetlands typically have a greater diaspore density than more stable, longer hydroperiod wetlands (Leck 1989). Sedges in particular (including sawgrass) produce long-lived seedbanks whose structure is determined by seed characteristics, variable temporal seed production, and dispersal patterns (Leck and Schutz 2005). Seedbank studies in the Everglades have been primarily limited to the northern Everglades (van der Valk and Rosburg 1997; Leeds et al. 2002; Smith et al. 2002; Vaithiyanathan et al. 1998; Miao and Zou 2009). Published seedbank studies in the Southern Everglades are lacking. This study evaluates variation in seedbank structure around sawgrass patches in northwestern Shark River Slough, Everglades National Park. 


\section{MATERIALS and METHODS}

\section{a. Study site}

Field work was conducted in the area south of US 41 (Tamiami Trail) on the northwest edge of the Shark River Slough within Everglades National Park (ENP). The sites were located east of Tram Road between latitude $25^{\circ} 39.77^{\prime} \mathrm{N}$ and $25^{\circ} 41.89^{\prime} \mathrm{N}$, and between longitude $80^{\circ} 45.22^{\prime} \mathrm{W}$ and $80^{\circ} 45.62^{\prime} \mathrm{W}$ (Fig. 1). The area was selected for its heterogeneity, with sawgrass patches surrounded by open water areas, as well as patches interconnected with wet prairie dominants, Eleocharis cellulosa and Rhynchospora tracyi. The area has marl, peat, and marl with peat substrates, along with areas interspersed with limestone rock outcroppings (pinnacle rock) (Table 1). Surface flow rates and water depth are variable, and the area is distant from agricultural influences. The area was therefore chosen as a representative example of the interactions of vegetation, flow dynamics, and hydrochorous dispersal in the Everglades.

\section{b. Germination (seedling emergence) assay analysis of seedbank}

A nested block design was employed in sampling soil for the germination assay analysis of the sawgrass soil seedbank in order to measure variations by patch side, edge, and species. In January 2003, at the east, north, and west sides of 10 sawgrass patches, five 100 $\mathrm{cm}^{2} \times 5 \mathrm{~cm}$ deep soil samples were taken at each of three patch edge locations (Fig. 2): 1) into the edge $(-1 \mathrm{~m}) ; 2)$ the actual edge $(0 \mathrm{~m})$; and 3$)$ to the outside of the edge $(+1 \mathrm{~m})$. The five $500 \mathrm{~cm}^{3}$ sub-samples along each 1-meter transect were combined into a $2,500 \mathrm{~cm}^{3}$ sample. The nested sampling design provided three combined samples (for each of $-1 \mathrm{~m}, 0$ $\mathrm{m}$, and $+1 \mathrm{~m}$ ) at the east, north, and west patch Sides, or 9 samples per patch, and 90 total samples from the 10 sawgrass patch sites (Fig. 2). Sampling along the south side was planned originally, but was not possible because sawgrass patch edges were not well-defined on that side. The 90 combined samples were refrigerated at $5^{\circ} \mathrm{C}$ until processing was complete to 
reduce fungal decay and to provide chilling to enhance seed germination (Vivian-Smith 1997; van der Valk and Rosburg 1997; Leeds et al. 2002; Vleeshouwers et al. 1995; Kirkman and Sharitz 1994). Chilling has been noted to cue germination among marsh seedbank seeds (Ponzio et al. 1995).

Each of the combined soil samples was sifted through a $6 \mathrm{~mm}(0.25$ ”) mesh to remove rocks, shells, and large plant matter. A $200 \mathrm{~cm}^{3}$ volume of this sifted soil was layered over a $600 \mathrm{~cm}^{3}$ volume of silica sand in each $15 \mathrm{~cm} \times 15 \mathrm{~cm}$ germination tray, resulting in a soil layer about $1 \mathrm{~cm}$ deep. Trays were placed on modified nursery benches flooded at two water levels, half at $+1 \mathrm{~cm}$ above the surface soil (inundated) and half at $-1 \mathrm{~cm}$ below the surface (saturated). (Earlier it was found that inundation greater than $+1 \mathrm{~cm}$ generated surface algal mats that lifted and confounded seedling data.) There were two replicates for each sample under each hydrology treatment. For each patch site, 12 trays were generated for each Side with four trays for each Edge distance $(+1 \mathrm{~m}, 0 \mathrm{~m}$, and $-1 \mathrm{~m})$ or 36 trays for each of the ten patches (Fig. 2). The outside nursery structure had a clear plastic roof with wire mesh sides to eliminate splashing from heavy rains, bird interference, and litter contamination. Water levels were adjusted daily by automated drip irrigation.

Germination (seedling emergence) provides a measure of seedbank structure (Poiani and Johnson 1988). New seedlings were counted every two weeks, identified to species and then removed from their trays, since some species rapidly produced stolons (e.g., Eleocharis cellulosa), which would give erroneous counts as new sprouts emerged. The germination assay was started the third week of March 2003 and ran until no seedlings appeared for two successive biweekly checks; this was 30 weeks later in mid October. The timing for the study was chosen to match ambient conditions of wet and dry season months.

\section{c. Diaspore assay analysis for visible seeds}


To determine if viable seeds remained in the samples, twenty five soil samples were selected randomly from the 90 total collected soil samples. Sampling also included a few samples that had produced no germinations in the seedling assay analysis. From each of these selected 25 soil samples, $100 \mathrm{~cm}^{3}$ of soil (sifted of rocks and roots) was washed through a $0.70 \mathrm{~mm}$ mesh to remove the finer marl and muck. The sifted remains were examined under a dissecting microscope for intact (undamaged) diaspores according to van der Valk and Rosburg (1997). All diaspores were identified to species with the aid of a diaspore reference collection created from known species (Appendix A). The intact diaspores provided a measure of potentially seeds that were not cued to germinate or were inviable.

\section{d. Diaspore movement in the field}

To visualize and measure the diaspore dispersal process in the Everglades and to test the hypothesis that plant patches catch and hold diaspores, a $20 \mathrm{~cm}^{3}$ volume (approximately 1,250 dyed sawgrass diaspores) were released between two sawgrass patches near site 10 in a flow channel. In this slough, on 11 August 2003, the surface flow was $1.3 \mathrm{~cm} / \mathrm{sec}$.

\section{e. Buoyancy}

To test the hypothesis that diaspore characters influence ability and length of floating, two units of 50 diaspores of each available species in the study area were placed in water and monitored daily. Buoyancy was measured in $\mathrm{FD}_{50}$ units, or the number of days into the study at which $50 \%$ of the test diaspores remained floating (Chapter II).

\section{f. Surface flow}

To determine the direction and intensity of surface flow in the study area, the surface flow velocity was measured weekly from mid-June to mid-August 2003. A small wooden block (mass $=7 \mathrm{~g}$ ), of nearly neutral density, was used for these measurements. The distance the floating block moved in one minute was measured and converted to $\mathrm{cm} / \mathrm{sec}$ units. All values were averaged to determine the mean surface flow velocity for the season. 


\section{g. Statistical analysis}

Since there were so many zeros from trays with no germinations, before analysis the germination assay data were converted to a Poisson distribution to and then arcsine (SqRt $(($ observed +0.375$) / 90.75))$ transformed to convert binary data into proportions and to eliminate zeros. The resulting normalized distribution of germinations was then processed by General Linear Models Analysis of Variance (GLM, ANOVA) with interaction and nested tests for significant variation among and between Sites, patch Sides, patch Edges, substrate hydrology, and trials using SYSTAT software (SPSS 1997). Germinations were then converted to the standard metric for germinations, seeds $/ \mathrm{m}^{2}$ (Leck 1989).

\section{h. Plant identification}

Plant nomenclature follows Wunderlin and Hansen (2003), though Godfrey and Wooten $(1979,1981)$ were used for species determinations. Vouchers were made from field material and from germinants in the seedling assay experiment, and were deposited in the Everglades National Park Herbarium. A 'diaspore atlas' was compiled from photographs to serve as an identification reference for both fresh diaspores as well as for seedbank diaspores (Appendix D).

\section{RESULTS}

\section{a. Germination seedling density assays}

After 18 weeks, $97.8 \%$ of the total germinations had occurred. The mean density for the 10 sites was $485.7 \pm 67$ S.E. diaspores $/ \mathrm{m}^{2}$, with $60 \%$ of the germinations from only 4 sites $(5,7,9$ and 10; Table 2). These 4 sites each had mean diaspore densities $>500$ diaspores $/ \mathrm{m}^{2}$ (Table 2 ). They differed from the other 6 sites by having predominantly marlbased substrate (Table 1). There were no germinations in 20 of the 90 original soil samples.

By species, eight of the 13 species accounted for $96 \%$ of all germinations.

Eleocharis cellulosa predominated with 100 of the 168 total germinations that occurred over 
26 weeks of the 30 -week study and germinations in $90 \%$ of the sites (Table 3 ). The mean species richness by site was 4.5 species (Table 2). Of the 13 species appearing among the 168 total germinations (Table 3), 10 species were present in the standing vegetation with a frequency range of common to abundant.

The mean species density by Site ranged from a high of $290.7 \pm 1.0$ S.E. diaspores $/ \mathrm{m}^{2}$ for Eleocharis cellulosa, to a low of $2.9 \pm 0.1$ S.E. diaspores $/ \mathrm{m}^{2}$ for Utricularia gibba (Table 4). The four species with the highest site densities were Eleocharis cellulosa, Sagittaria lancifolia, Rhynchospora tracyi, and Cladium jamaicense; each of these species had $>20$ germinations $/ \mathrm{m}^{2}$ (Table 3). These four species also occurred at $50 \%$ of the 10 sites, and all were common species in the standing vegetation (Table 3). Of these four species, all but Sagittaria lancifolia had the greatest diaspore density on the north side of the patch (Table 4).

By patch Side, the mean seed densities were $150.8 \pm 30$ S.E. diaspores $/ \mathrm{m}^{2}$ for the east side, $199.7 \pm 37$ S.E. diaspores $/ \mathrm{m}^{2}$ for the north side, and $135.4 \pm 28$ S.E. diaspores $/ \mathrm{m}^{2}$ for the west side. At the patch Edge the mean density was $109.9 \pm 28$ S.E. diaspores $/ \mathrm{m}^{2}$ for $+1 \mathrm{~m}$ (outer), $183.1 \pm 37$ S.E. diaspores $/ \mathrm{m}^{2}$ for $0 \mathrm{~m}$, and $192.5 \pm 25$ S.E. diaspores $/ \mathrm{m}^{2}$ for $-1 \mathrm{~m}$ (inner) (Table 5). Both patch Edge $(p=0.013)$ and the interaction of Site $\mathrm{x}$ Side were significant $(p=0.038)$ at the $95 \%$ level (Table 6 ) at influencing the numbers of germinations - or at catching seeds along sawgrass patch edges.

\section{b. Hydrology treatments}

During the first 10 weeks of the 30 -week monitoring period, more germinations occurred under moist (saturated) substrate than under flooded substrate (Fig. 3). Thereafter, germinations under flooded substrate dominated. However, these differences were only trends, and not statistically significant. In the two hydrology treatments, of 180 trays in each of the saturated and flooded substrate treatments, the mean germination densities were 206.6 
\pm 8.1 S.E. diaspores $/ \mathrm{m}^{2}$ in flooded substrate, and $279.7 \pm 13.6$ S.E. diaspores $/ \mathrm{m}^{2}$ in saturated substrate (Table 3). This difference is not significant at the 95\% level ( $p=0.634$; Table 6). However, Cladium jamaicense, Eleocharis cellulosa, and Rhynchospora tracyi had noticeably larger densities under saturated substrate than under flooded substrate, while Sagittaria lancifolia, Typha domingensis, Utricularia purpurea, and U. resupinata had many more germinations under flooded substrate (Table 3).

\section{c. Diaspore assay analysis}

Only the sedge species Cladium jamaicense, Eleocharis cellulosa, and Rhynchospora tracyi were found in the soil samples evaluated for intact diaspores. In this analysis, the ungerminated intact seeds in subsamples, from 25 of 90 collected soil samples, had a mean density of $370.1 \pm 82$ S.E. seeds $/ \mathrm{m}^{2}$. For comparison, the mean density for germinations in the same 25 soil samples was $56.3 \pm 13$ S.E. seeds $/ \mathrm{m}^{2}$, or $15.1 \%$ of the intact seedbank density (Table 7).

\section{d. Sawgrass diaspore dispersal study}

Sawgrass diaspores were released on the water surface of a $60 \mathrm{~cm}$ deep slough with a marl and limestone bedrock base. The surface flow rate in the slough was $1.3 \mathrm{~cm} / \mathrm{sec}$. Sparse patches of Eleocharis cellulosa culms were adjacent to the bordering sawgrass patches. Pieces of floating algal mat from about $2 \mathrm{~cm}$ to $30 \mathrm{~cm}$ in diameter were present. All submerged culms were coated with periphyton sheaths. Sawgrass diaspore movement was monitored until all diaspores had adhered to periphyton, about 30 minutes. Specifically, diaspores quickly adhered to each other, to periphyton culm sheaths, to edges of floating algal mats, and to the center surfaces of those mats with hanging edges. As floating periphyton pieces moved and collided, some of their attached diaspores became dislodged. These diaspores followed a cycle of detachment and reattachment from one periphyton piece to another. Upon colliding with vertical plant culms, small diaspore-bearing mat pieces $(2-4 \mathrm{~cm}$ 
in diameter) would spin about as they transferred diaspores to culms, and continued drifting. Ultimately, the small pieces linked with other floating periphyton pieces or attached to periphyton sheaths surrounding culms. Large algal mat pieces carrying diaspores came to rest against the outer culms of plant patches, while small algal mat pieces carrying diaspores drifted into the interior of sawgrass patches.

\section{e. Buoyancy and surface flow velocity}

Diaspores of the four dominant species in the germination assay analysis are all buoyant. The $\mathrm{FD}_{50}$ buoyancy values (days for $50 \%$ of diaspores to sink), determined in another study were: Cladium jamaicense $=12$ days; Eleocharis cellulosa $=4$ days; Rhynchospora tracyi $=3$ days; and Sagittaria lancifolia $=4$ days (Appendix C).

Measured weekly from mid-June to mid-August, the mean slough surface water velocity for the southern sites $(1-5)$ was $3.1 \mathrm{~cm} / \mathrm{sec}$., and for the northern sites (6 - 10) it was $2.9 \mathrm{~cm} / \mathrm{sec}$. Mean water depth near Sites $1-5$ consistently was $5-10 \mathrm{~cm}$ higher than near Sites 6-10 throughout flooding in 2003.

The lower stream flow was from $20^{\circ}-40^{\circ}$ east of north, as determined from the direction of flattened, submersed spikerush culms and the measurement of flow direction of stirred silt. However, surface flow was typically from a different direction than that of the general lower stream current since surface flow fluctuates in both direction and intensity depending upon wind, influencing fetch dynamics (Great Lakes Environmental Research Lab 2009).

\section{DISCUSSION}

\section{a. Sawgrass patch interception of diaspores}

Both patch Edge $(0 \mathrm{~m})$ and Inner patch $(-1 \mathrm{~m})$ means $\left(0 \mathrm{~m}=14.1 \pm 9.0\right.$ S.E. seeds $/ \mathrm{m}^{2}$, $-1 \mathrm{~m}=14.8 \pm 7.7$ S.E. seeds $\left./ \mathrm{m}^{2}\right)$ were higher than the Outer patch mean $(+1 \mathrm{~m}=8.5 \pm 5.0$

S.E. seeds $/ \mathrm{m}^{2}$ ), supporting the hypothesis that patch Edge intercepts diaspores dispersed by 
hydrochory $(p=0.013)$. Site $x$ Side interaction had a significant effect $(p=0.038)$ on the number of seeds in the seedbank. Patch Side did not vary significantly (Table 6), although 5 out of 13 species had the largest number of germinations at the north Side (Table 4). The highest densities for 9 species were at the patch Edge $(0 \mathrm{~m})$ and Inner $(-1 \mathrm{~m})$ patch (Table 4). Small floating periphyton mats with their cargo of diaspores drifting between culms and deeper into a sawgrass patch may explain this edge pattern. Larger periphyton mats with their cargo of diaspores are intercepted by the rigid sawgrass culms at the patch edge.

However, two observations made at Sites 3 and 4 confound patch data. Over the course of one year, outward growth at portions of sawgrass patches expanded the edge by nearly a meter. Therefore, this year's $(-1 \mathrm{~m})$ inner measurement may be last year's actual edge $(0 \mathrm{~m})$. At Site 2 , alligator(s) making their way along the patch edge had dug and mixed a 0.6 to $1 \mathrm{~m}$ wide strip of soil. These observations lend support to the concept of a dynamic edge in sawgrass patches.

\section{b. The hydrochory dispersal process}

There are several effects of wind on water surfaces. After local heavy rainfall, water becomes mounded or 'humped' and may take days to flatten (Craighead 1971). High winds also force water into mounds, causing an increased surface flow (Great Lakes Environmental Research Lab 2009). For example, near Site 10 the day following a heavy rainstorm (25 June 2003), the surface flow rate of a slough was $4.3 \mathrm{~cm} / \mathrm{sec}$. Leonard et al. (2006) recorded the mean flow rate of the 2003-2004 wet season in central SRS as less than $2.0 \mathrm{~cm} / \mathrm{sec}$. The latter measurement is of the deeper, more consistent stream flow measured at $6 / 10$ of the water column height, while the surface flow is strongly influenced by fetch dynamics, a term commonly used for lakes and ponds (Great Lakes Environmental Research Lab 2009). Fetch dynamics result from winds causing air-to-water friction and floating matter movement (Leonard et al. 2006). Fetch is dependent upon wind velocity, distance of water over which 
the wind blows, and duration (Great Lakes Environmental Research Lab 2009). The Everglades is thus a blend of stream and lake, according to hydrology dynamics observations. With no wind, the lower stream flow predominates, while during strong winds, stream flow and surface flow are additive. Since floating diaspores and floating algal mats are situated on the water's surface, their movement is most strongly influenced by wind and the concurrent impact of floating plants (e.g., Utricularia spp.) and stem-generated turbulence (Leonard et al. 2006).

Turbulence is a major factor affecting surface flow (Leonard et al. 2006). A quantitative expression of small-scale flow turbulence is the Reynolds number, $\operatorname{Re}_{\mathrm{d}}$. This is the ratio of inertia to viscosity of liquid in a flow field. As $\mathrm{Re}_{\mathrm{d}}$ increases, flow turbulence increases (Leonard et al. 2006). Thus, with an increase in water flow velocity, distance, and turbulence are enhanced along with diaspore movement (hydrochory). Leonard et al. (2006) calculated that if the lower stream flow velocity reaches $3-5 \mathrm{~cm} / \mathrm{sec}$, or if stem diameters become larger by growing periphyton sheaths, stem-generated stream flow turbulence may be formed.

In this Shark River Slough study, four surface flow measurements (3.2 to 4.3 $\mathrm{cm} / \mathrm{sec}$ ) in the turbulence range were recorded between 25 June and 28 July 2003 . If velocities greater than $3-5 \mathrm{~cm} / \mathrm{sec}$ cause turbulence in the lower stream flow, then turbulence likewise may have been present in the surface flow, and thereby facilitated hydrochorous dispersal into and among sawgrass patch edges.

In the Everglades, successful distant hydrochorous dispersal thus probably depends mostly upon sporadic tropical storm events that significantly increase the water level, dislodge mature diaspores from plants, and generate both greater stream flow and surface flow (USGS 2004). Graphs of seed dispersal distance for most plant species display a longtapered tail. A few seeds can travel long distances when storm events occur, while most seeds 
disperse locally (Fenner and Thompson 2005). For example, the morning after a large storm in July 2003, algal mats up to $40 \mathrm{~cm}$ across were observed along sawgrass patch edges. This was caused by the rapid increase in water level from heavy rainfall and water mounding from increased fetch dynamics. The result was mats forced into stacks up to four layers deep along the east patch edge. Small mats $2-4 \mathrm{~cm}$ in diameter were forced deeper into the sawgrass patch.

Storms and increased flow should be capable of reshaping sawgrass patch edges with the increased energy of water pulses, fetch dynamics, and stream flow (USGS 2004; Larsen et al. 2009). Historically, the greater water volume and flow rate are thought to have been fundamentally important in moving sediments — including diaspores — into sawgrass patch edges (Larsen et al. 2007; Larsen et al. 2009). Here, seeds could germinate, and consequently aid in generating the vegetation patterning typical of the ridge and slough Everglades landscape. Intense storms and greater flow cause scouring and mixing of substrate, reshaping of patch edges, exposure of seedbank seeds, greater diaspore dispersal, and greater heterogeneity in the ecosystem (Larsen et al. 2009). With greater elevations of water during storms, storm matter-litter, sediments, and both fresh as well as seedbank-dislodged diaspores - is also probably raised higher to the tops and into edges of sawgrass patches (Leonard et al. 2006), resulting in an increase in patch mass, seedbank diaspores, and germinations.

Successful hydrochorous dispersal is based upon a combination of environmental factors as well as functional traits that enhance dispersal, such as diaspore size, adhesive ability, buoyancy, and diaspore dispersal timed with flooding. The dominant species, Cladium jamaicense, Eleocharis cellulosa, Rhynchospora tracyi, and Sagittaria lancifolia, all release diaspores during the rainy season, and have buoyancies $\left(\mathrm{FD}_{50}\right)$ from 3 to 12 days (Appendix C). The mean surface flow rate of sloughs in the study area, from June to August 
2003, was $3.0 \mathrm{~cm} / \mathrm{sec}$. At this velocity, unimpeded hydrochory could move diaspores up to $2.6 \mathrm{~km} /$ day, but the velocity is inversely related to diaspore size according to the Law of Momentum $\left(\mathrm{m}_{1} \mathrm{v}_{1}=\mathrm{m}_{2} \mathrm{v}_{2}\right)$ (Table 8). If unimpeded, and coupled with adequate open water, significant dispersal may occur even with an $\mathrm{FD}_{50}$ buoyancy of one or two days, and even nonbuoyant diaspores could successfully disperse by hydrochory if attached to algal mats.

\section{c. Community perspective:}

Of the 13 species in the germination assay analysis, 10 were in the frequency range of common to abundant in the standing vegetation, and the dominant seedbank species were also the dominant standing plant species. The strong seedbank-to-existing vegetation correlation has not been observed in other published germination assay seedbank studies from the northern Everglades (van der Valk and Rosburg 1997; Leeds et al. 2002; Smith et al. 2002; Miao and Zou 2009). The common species found in the northern WCA-2A Everglades studies do not coincide with the common species found in this study. Only one to three species are in common with two of these studies (van der Valk and Rosburg 1997; Leeds et al. 2002) (Appendix E). In the present study, the correlation of standing vegetation with seedbank germinations is more typical of disturbed short-hydroperiod wetlands than of those with long and stable hydroperiods in a pooled marsh such as the northern WCA-2A Everglades seedbank studies (Leck 1989).

Of the standing vegetation in the study area, 27 species are considered historic marsh species (Smith et al. 2002; Loveless 1959) (Appendix E). The germination assay of this Shark River Slough study contained seven species: Bacopa caroliniana, Cladium jamaicense, Eleocharis cellulosa, Polygonum hydropiperoides, Rhynchospora tracyi, Sagittaria lancifolia, and Typha domingensis that are considered historical species of Everglades marsh 
communities. Furthermore, Eleocharis cellulosa and Rhynchospora tracyi, are indicative of more pristine habitats (Leeds et al. 2006) (Appendix E). The fact that these two species are dominant in the germination assay and very abundant in the diaspore seed assay lends support to the designation of this section of Shark River Slough as a relatively pristine habitat (Leeds et al. 2006) (Appendix E).

In the germination assay analysis of this Shark River Slough study, Eleocharis cellulosa and Rhynchospora tracyi constituted $64 \%$ of all germinations but were either absent from, or weakly represented in, northern seedbank studies (Table 2, Appendix E). The only seedbank analysis near the current study site was performed on soil collected north of the Tamiami Trail in central WCA-3A (J. H. Richards and S. Coyne unpublished data). The hydroperiod in that collection area is longer than this more southern Shark River Slough, Everglades National Park site, and is maintained by levees constructed in the late 1960's (Craighead 1971). While 15 species were found by germination assay in their WCA-3A site, only six species were in common with this study, a few kilometers to the south and south of the Tamiami Trail. The two dominant species in WCA-3A, Nymphaea odorata and Eleocharis elongata, did not occur in the current SRS study (Fig. 4). Instead, the three dominant species were Eleocharis cellulosa, Sagittaria lancifolia, and Cladium jamaicense. The percentages of total germinations of these three species were about eight times larger in the current SRS study than in the WCA-3A study (Fig. 4). The variation in seedbank composition between these two sites may also reflect differences in recent ecological trait filtration due to various disturbances such as the anthropogenic manipulation of Everglades hydrology in the Southern Everglades.

\section{d. Seed viability and seedling emergence rates}

The germination (seedling emergence) percentages for diaspores of dominant Everglades marsh species (Cladium jamaicense $=18 \%$, Eleocharis cellulosa $=16 \%$, 
Pontederia lanceolata $=25 \%$, Sagittaria lancifolia $=29 \%$ ) show that even fresh seed germinate at a low rate (Sutton 1993; Chapter IV). In a sawgrass germination study only $4.8 \%$ of ungerminated sawgrass seeds were considered viable (Chapter IV). Thus, the usual counting of intact sawgrass diaspores by seed assay analysis, and assuming that most have potentially viable seeds, would therefore be erroneous for the Everglades. For example, testing for the germination ability of intact diaspores in a northern Everglades seedbank study resulted in germinations of only $1.3 \%$ of seeds (van der Valk and Rosburg 1997). However, some seeds may not have been cued to germinate.

Sexual reproduction probably preceded the evolution of clonality, and clonal propagation is most developed in species with long distance dispersal where clonal growth follows initial recruitment (Eriksson 1992). Ecological trait filtration over the past 5,000 years, in the disturbance-prone Everglades ecosystem, has apparently favored functional traits for clonal reproduction. This may explain the large number of nonviable seeds produced among plant populations, but seed formation and germination is known to vary among species, among populations, and among years (Bonis et al. 1995; Chapter IV).

Other factors in germination success include the age of seedbank seeds and allied environmental chemicals. As seeds age, the germination rates of seedbank seeds often decline, and the amount of decline varies among species (Fenner and Thompson 2005). For example, Rhynchospora tracyi germination significantly decreases between 3 - 5 months post burial, and certain nutrients and plant extracts also influence germination. Eleocharis cellulosa germination significantly decreases in high $\mathrm{P}$ soils, and Rhynchospora tracyi germination is significantly reduced by Typha extracts (Leeds et al. 2006).

The mean germination density for this southern Everglades Shark River Slough study is compatible with other seedbank studies made in WCA-2A of the northern Everglades. The mean site germination density for this study was $486 \mathrm{seeds} / \mathrm{m}^{2}$, while the mean transect 
germination density for van der Valk and Rosburg (1997) in WCA-2A was 274 seeds $/ \mathrm{m}^{2}$ and for Miao and Zou (2009) in WCA-2A the mean transect germination density for a more pristine site was $497 \mathrm{seeds} / \mathrm{m}^{2}$ and for a highly nutrient-enriched site the mean was 4643 seeds $/ \mathrm{m}^{2}$ (Appendix F). The germination densities from the current Shark River Slough and WCA -2A seedbank studies are at the low end of the range expected for freshwater marshes. The expected freshwater marsh range is 695 - 255,000 seeds $/ \mathrm{m}^{2}$ (Leck 1989).

Sawgrass ridges in the historical ridge and slough landscape are hypothesized to have been maintained by the trapping of particles and floating litter by plants along sawgrass patch edges. This newly accreted matter maintained the ridge in equilibrium with removal processes (Larsen et al. 2007). Accordingly, the exposed new matter containing a seedbank provided a site for germination as water levels seasonally declined. Sawgrass seeds, for example, are known to germinate on grounded algal mats and on muck surfaces (van der Valk and Rosburg 1997; Lorensen et al. 2000). Besides sawgrass, Rhynchospora tracyi and Eleocharis cellulosa seeds germinate more effectively in saturated soil than in flooded soil (Table 3) (Ponzio et al. 1995). Therefore, sawgrass patch edges provide the saturated soil environment that is appropriate for the germination of the above species as water levels decline.

\section{CONCLUSIONS}

Most Everglades seeds possess adequate buoyancy to be transported by flowing water. Flow tests show that seeds can also move by rafting on periphyton (phycochory). Wind and storm dynamics have demonstrated how seed-bearing periphyton can be forced into sawgrass patch edges. The north Side of patches had the highest seed density. Patch edge and $-1 \mathrm{~m}$ into the patch had the highest Edge seed density.

This study shows that diaspores of species considered dominant in the historic Everglades are commonly caught by sawgrass patches. Seeds of three dominant species, 
Cladium jamaicense, Eleocharis cellulosa, and Rhynchospora tracyi, collected with greatest density at the patch edge and $-1 \mathrm{~m}$ into the patch of sawgrass. The fact that Eleocharis and Rhynchospora are commonly found growing around the edges of sawgrass patches supports the role of sawgrass patch edges as interceptors as well as potential germination seedbeds for these species.

The general correlation of standing vegetation with seedbank structure in the southern Everglades is congruent with wetlands characterized by disturbance. The strong similarity of seedbank species and standing vegetation species here is also evidence of the plant community's resilience to disturbance.

Water flow and storm surges are probably necessary for proper sawgrass patch reshaping and adequate diaspore dispersal. Although the existing water flow in Everglades National Park is adequate to provide for some hydrochorous dispersal, with further ecological restoration efforts, an increase in flow and storm pulses should take place. Sloughs would then be converted into riverine flows which would scour patch edges, fragment extensive homogeneous sawgrass patches and enhance seed dispersal. More emphasis on the species composition upstream is also necessary for potential future plant community transformations, as Everglades ecological restoration plans are developed. 


\section{LITERATURE CITED}

Bonis, A., J. Lepart and P. Grillas. 1995. Seed bank dynamics and coexistence of annual macrophytes in a temporary and variable habitat. Oikos 74:81-92.

Casanova, M. T. and M. A. Brock. 2000. How do depth, duration and frequency of flooding influence the establishment of wetland plant communities? Plant Ecology 147:237250.

Chambers, J. C. and J.A. MacMahon. 1994. A day in the life of a seed: Movements and fates of seeds and their implications for natural and managed systems. Annual Review of Ecology and Systematics 25:263-92.

Chang, E.R., R.L. Jefferies and T.J. Carleton. 2001. Relationship between vegetation and soil seed banks in an arctic coastal marsh. Journal of Ecology 89:367-384.

Craighead, F. C. 1971. The Trees of South Florida: Volume I - The Natural Environments and Their Succession. Univ. Miami Press. Coral Gables, FL. 212 pp.

David, P. G. 1996. Changes in plant communities relative to hydrologic conditions in the Florida Everglades. Wetlands 16:15-23.

DeAngelis, D. L. and P. S. White. 1994. Ecosystems as products of spatially and temporally varying driving forces, ecological processes, and landscapes: a theoretical perspective. Pgs. 9-27 in: Everglades: the Ecosystem and its Restoration, S. M. Davis and J. C. Ogden (eds.). St. Lucie Press. Boca Raton, FL

Eriksson, O. 1992. Evolution of seed dispersal and recruitment in clonal plants. Oikos 63:439-448.

Duever, M. J., J. F. Meeder, L. C. Meeder, and J. M. McCollum. 1994. The climate of South Florida and its role in shaping the Everglades ecosystem. Pgs. 225-248 in: Everglades: the Ecosystem and its Restoration, S. M. Davis and J. C. Ogden (eds.). St. Lucie Press. Boca Raton, FL

Facelli, J.M. and S.T.A. Pickett. 1991. Plant litter: its dynamics and effects on plant community structure. The Botanical Review 57:1-32.

Fenner, M. and K. Thompson. 2005. The Ecology of Seeds. Cambridge University Press. Cambridge, U.K. 250 pp.

Gerritsen J. and H. S. Greening. 1989. Marsh seed banks of the Okefenokee Swamp: effects of hydrologic regime and nutrients. Ecology 70:750-763

Godfrey, R. K. and J. W. Wooten. 1979. Aquatic and Wetland Plants of Southeastern United States: Monocotyledons. University Georgia Press. Athens, GA. 712 pp.

Godfrey, R. K. and J. W. Wooten. 1981. Aquatic and wetland plants of Southeastern United States: Dicotyledons. Univ. Georgia Press. Athens, GA. 932 pp. 
Goodrick, R. L. 1974. The wet prairies of the Northern Everglades. Pgs. 47-52 in:

Environments of South Florida: present and past, P. J. Gleason (ed.). Memoir 2: Miami Geological Soc. Miami, FL.

Great Lakes Environmental Research Laboratory. 2009. www.glerl.noaa.gov

Gunderson, L., H. 1994. Vegetation of the Everglades: Determinants of community composition. Pgs. 323-340 in: Everglades: the Ecosystem and its Restoration, S.M. Davis and J. C. Ogden (eds.). St. Lucie Press. Boca Raton, FL.

Kirkman, L. K. and R. R. Sharitz. 1994. Vegetation distribution and maintenance of diversity in intermittently flooded Carolina bays in South Carolina. Ecological Applications 4:177-188.

Larsen, L. G., J. W. Harvey and J. P. Crimaldi. 2007. A delicate balance: ecohydrological feedbacks governing landscape morphology in a lotic peatland. Ecological Monographs 77:591-614.

Larsen, L. G., J. W. Harvey and J. P. Crimaldi. 2009. Predicting bed shear stress and its role in sediment dynamics and restoration potential of the Everglades and other vegetated flow systems. Ecological Engineering 35:1773-1785.

Leck, M. A. and Schutz, W. 2005. Regeneration of Cyperaceae, with particular reference to seed ecology and seed banks. Perspectives in Plant Ecology and Systematics 7:95-133.

Leck, M. A. 1989. Wetland seed banks. Pgs. 283-305 in: Ecology of Soil Seed Banks, M. A. Leck, V. T. Parker, and R. L. Simpson (eds.). Academic Press, Inc. NY, NY

Leeds, J. A., S. Newman and S. M. Smith. 2006. Factors affecting seed germination of Eleocharis cellulosa and Rhynchospora tracyi from the Northern Everglades. Wetlands 26:368-375.

Leeds, J. A., S. M. Smith, and P. B. Garrett. 2002. Seedbanks and their potential role in the vegetation dynamics of a northern Everglades marsh. The Florida Scientist 65:16-34.

Leonard, L., A. Croft, D. Childers, S. Mitchell-Brukar, H. Solo-Gabriele, and M. Ross. 2006. Characteristics of surface-water flows in the ridge and slough landscape of Everglades National Park: implications for particulate transport. Hydrobiologia 569:5-22.

Lippitt, L. A. and L. A. Moran. 1993. Three quick seed evaluation methods-A comparison. Restoration and Management Notes 11:172.

Loveless, C. M. 1959. A study of the vegetation of the Florida Everglades. Ecology 40:1-9.

Miao, S. L. and C.B. Zou. 2009. Seasonal variation in seed bank composition and its interaction with nutrient enrichment in the Everglades wetlands. Aquatic Botany 90:157-164 
Olmsted, I. and T. V. Armentano. 1997. Vegetation of Shark Slough, Everglades National Park. SFNRC Tech. Rpt. 97-001. S. Fla. Nat. Res. Ctr., Everglades Nat. Park, Homestead, FL. 41 pp.

Parker, V. T. and V. R. Kelly. 1989. Seed banks in California chaparral and other Mediterranean climate shrublands. Pgs. 231-255 in: Ecology of Soil Seed Banks, M. A. Leck, V. T. Parker, and R. L. Simpson (eds). Academic Press, Inc. NY, NY.

Poiani, K.A. and W.C. Johnson. 1988. Evaluation of the emergence method in estimating seed bank composition of prairie wetlands. Aquatic Botany 32:91-97.

Ponzio, K. J., S. J. Miller, and M. A. Lee. 1995. Germination of sawgrass, Cladium jamaicensis Crantz under varying hydrologic conditions. Aquatic Botany 51:115-120.

Richards, J. H. and S. Coyne. Unpublished data on seedbanks collected 1997 from WCA-3A, Florida Everglades.

Ross, M. S., P. L. Ruiz, D. L. Reed, K. Jayachandran, C. L. Coultas, J. P. Sah, and M. T. Lewen. 2001. Assessment of marsh vegetation responses to hydrological restoration in Shark Slough, Everglades National Park. Final Report to Everglades National Park and Florida International University. Miami, FL. 48 pp.

Schneider, R. L. and R. R. Sharitz. 1988. Hydrochory and regeneration in a bald cypresswater tupelo swamp forest. Ecology 69:1055-1063.

Science Coordination Team. 2003. The role of flow in the Everglades ridge and slough landscape. Theme paper by South Florida Ecosystem Restoration Working Group. Miami, FL. Photocopy. 62 pp.

Smith, S. M., P. V. McCormick, J. A. Leeds, and P.B. Garrett. 2002. Constraints of seed bank composition and water depth for restoring vegetation in the Florida Everglades, USA. Restoration Ecology 10:138-145.

SPSS. 1997. SYSTAT 7.0: Statistics. SPSS, Inc. Chicago, IL. 751 pp.

Sutton, D. L. 1993. A method for germination of arrowhead, pickerelweed, and spikerush seeds. TropicLine (newsletter of Ft. Lauderdale Res. and Educ. Ctr., IFAS) 6:2-3.

Topozone.com [1990’s] Aerial photos of Shark River Slough area.

USGS. 2004. Introduction. In: The role of flow in the Everglades ridge and slough landscape. U.S. Dept. of the Interior. United States Geological Survey. South Florida Information Access website: sofia.usgs.gov/publications/papers/sct_flows

Vaithiyanathan, P, J. Zahina, S. Cooper, and C. J. Richardson. 1998. Examination of the Seedbank along a Eutrophication Gradient in the Northern Everglades. In: 1998 Duke Wetland Center Biennial Report on the Effects of Phosphorus and Hydroperiod Alterations on Ecosystem Structure and Function in the Everglades. Duke Univ., Durham, NC. (also 1997. Chapter 10. In 1996-97 Duke Wetland Center Biennial Report. Duke University. Durham, NC). 
van der Valk, A. G. 1978. The role of seed banks in the vegetation dynamics of prairie glacial marshes. Ecology 59:322-335.

van der Pijl, L. 1982. Principles of Dispersal in Higher Plants, $3^{\text {rd }}$ ed. Springer-Verlag. NY, NY. $215 \mathrm{pp}$.

van der Valk, A. G. and T. R. Rosburg. 1997. Seed bank composition along a phosphorus gradient in the Northern Florida Everglades. Wetlands 17:228-236.

Vleeshouwers, L. M., H. J. Bouwmeester, and C. M. Karssen. 1995. Redefining seed dormancy: an attempt to integrate physiology and ecology. J. Ecology 83: 1031-1037.

Vivian-Smith, G. 1997. Microtopographic heterogeneity and floristic diversity in experimental wetland communities. Journal of Ecology 85:71-82.

Wade, D., J. Ewel and R. Hofstetter. 1980. Fire in South Florida Ecosystems. U.S. Department of Agriculture Forest Service, General Technical Report. SE-17. S.E. Forest Experimental Station, Ashville, NC. 125 pp.

Wunderlin, R. P. and B. F. Hansen. 2003.Guide to the Vascular Plants of Florida, Second Edition. University Press of Fla. Gainesville, FL. 787 pp. 
Table 1. Location of the 10 seedbank study sites in Shark River Slough, ENP. Both latitudelongitude and UTM methods of location are given for convenience. Observational notes of hydrology, soil, and plant community are summarized.

\begin{tabular}{|c|c|c|c|}
\hline Site & Lat. \& Long & UTM Locatio & Site Notes \\
\hline 1. & $\begin{array}{r}25^{\circ} 39.77^{\prime} \mathrm{N} \\
80^{\circ} 45.58^{\prime} \mathrm{W}\end{array}$ & $\begin{array}{r}17 \mathrm{R} 0524120.3 \\
2838367.5\end{array}$ & $\begin{array}{l}\text { Organic soil, dense Eleocharis cellulosa surrounding } \\
\text { a tall sawgrass patch. Deepest water of all sites. }\end{array}$ \\
\hline 2. & $\begin{array}{r}25^{\circ} 40.10^{\prime} \mathrm{N} \\
80^{\circ} 45.50^{\prime} \mathrm{W}\end{array}$ & $\begin{array}{r}17 \mathrm{R} 524253.0 \\
2838976.8\end{array}$ & $\begin{array}{l}\text { Organic soil; patchy Eleocharis cellulosa around tall } \\
\text { sawgrass patch. }\end{array}$ \\
\hline 3. & $\begin{array}{r}25^{\circ} 40.13^{\prime} \mathrm{N} \\
80^{\circ} 45.54^{\prime} \mathrm{W}\end{array}$ & $\begin{array}{r}17 \mathrm{R} 524186.0 \\
2839032.1\end{array}$ & Same as \#2. \\
\hline 4. & $\begin{array}{r}25^{\circ} 40.21^{\prime} \mathrm{N} \\
80^{\circ} 45.46^{\prime} \mathrm{W}\end{array}$ & $\begin{array}{r}17 \mathrm{R} 524319.5 \\
2839180.0\end{array}$ & Same as \#2. \\
\hline 5. & $\begin{array}{r}25^{\circ} 40.28^{\prime} \mathrm{N} \\
80^{\circ} 45.48^{\prime} \mathrm{W}\end{array}$ & $\begin{array}{r}\text { 17R 524285.8 } \\
2839309.1\end{array}$ & $\begin{array}{l}\text { Evidence of old tree isle burn; nearby exposed } \\
\text { pinnacle rock and substrate organic overlain with } \\
\text { marl layer. Sparse spikerush surrounding a sparse } \\
\text { sawgrass patch. Surrounding area with much open } \\
\text { water }\end{array}$ \\
\hline 6. & $\begin{array}{r}25^{\circ} 41.50^{\prime} \mathrm{N} \\
80^{\circ} 45.44^{\prime} \mathrm{W}\end{array}$ & $\begin{array}{r}\text { 17R 524348.6 } \\
2841561.0\end{array}$ & $\begin{array}{l}\text { Substrate marl-organic. Evidence of old burn; } \\
\text { pinnacle rock adjacent. Sparse saw-grass surrounded } \\
\text { by many 1-3 m dia. sawgrass patches. Limited open } \\
\text { water. }\end{array}$ \\
\hline 7. & $\begin{array}{r}25^{\circ} 41.53^{\prime} \mathrm{N} \\
80^{\circ} 45.37^{\prime} \mathrm{W}\end{array}$ & $\begin{array}{r}\text { 17R 524465.5 } \\
2841616.6\end{array}$ & $\begin{array}{l}\text { Marl-organic substrate with patches of sparse } \\
\text { Eleocharis cellulosa \& sawgrass scattered among } \\
\text { open water areas. }\end{array}$ \\
\hline 8. & $\begin{array}{r}25^{\circ} 41.64^{\prime} \mathrm{N} \\
80^{\circ} 45.22^{\prime} \mathrm{W}\end{array}$ & $\begin{array}{r}17 \mathrm{R} 524716.0 \\
2841820.0\end{array}$ & $\begin{array}{l}\text { Adjacent areas with several small sawgrass patches; } \\
\text { open water along west side. Substrate marly. }\end{array}$ \\
\hline 9. & $\begin{array}{r}25^{\circ} 41.64^{\prime} \mathrm{N} \\
80^{\circ} 45.52^{\prime} \mathrm{W}\end{array}$ & $\begin{array}{r}17 \mathrm{R} 524214.3 \\
2841819.1\end{array}$ & $\begin{array}{l}\text { Pinnacle rock. Marl-organic substrate. Extensive } \\
\text { open water in surrounding area with sparse spikerush } \\
\text { among tall sawgrass patches. }\end{array}$ \\
\hline 10. & $\begin{array}{r}25^{\circ} 41.89^{\prime} \mathrm{N} \\
80^{\circ} 45.62^{\prime} \mathrm{W}\end{array}$ & $\begin{array}{r}17 \mathrm{R} 524046.3 \\
2842280.3\end{array}$ & $\begin{array}{l}\text { Same as \#7. Extensive marl over patches of elevated } \\
\text { bedrock. Patches of sawgrass among sparse } \\
\text { spikerush. }\end{array}$ \\
\hline
\end{tabular}


Table 2. Summary of number of species by patch Sides and Edges with mean seed densities.

The absolute variation, C.V., reflects less variation by patch Side $(58-66 \%)$ than by patch

Edge $(42-80 \%)$. See Figure 2 for sampling details. Densities $=$ seeds $/ \mathrm{m}^{2} \pm$ S.E.

\begin{tabular}{|c|c|c|c|c|c|c|c|c|c|c|}
\hline Site & $\begin{array}{c}\# \\
\text { Germ }\end{array}$ & $\begin{array}{c}\% \\
\text { Total }\end{array}$ & $\begin{array}{c}\# \\
\text { Spp. }\end{array}$ & $\begin{array}{c}\mathbf{E} \\
\text { Side }\end{array}$ & $\begin{array}{c}\mathbf{N} \\
\text { Side }\end{array}$ & $\begin{array}{c}\text { W } \\
\text { Side }\end{array}$ & $\begin{array}{c}\text { Outer } \\
\text { Edge } \\
(+1 \mathrm{~m})\end{array}$ & $\begin{array}{c}\text { Actual } \\
\text { Edge } \\
(0 \mathrm{~m})\end{array}$ & $\begin{array}{l}\text { Inner } \\
\text { Edge } \\
(-1 \mathrm{~m})\end{array}$ & $\begin{array}{c}\text { Mean } \\
\text { Site } \\
\text { Den. }\end{array}$ \\
\hline 1 & 11 & 6.6 & 6 & $\begin{array}{r}117.0 \\
\pm 5.0\end{array}$ & $\begin{array}{r}65.6 \\
+5.3\end{array}$ & $\begin{array}{r}188.9 \\
\pm 7.1\end{array}$ & $\begin{array}{r}163.4 \\
\pm 7.3\end{array}$ & $\begin{array}{r}90.0 \\
+5.4\end{array}$ & $\begin{array}{r}117.1 \\
\pm 5.1\end{array}$ & $\begin{array}{r}370.5 \\
\pm 3.4\end{array}$ \\
\hline 2 & 11 & 6.6 & 4 & $\begin{array}{r}208.9 \\
+4.5\end{array}$ & $\begin{array}{r}29.8 \\
+2.5\end{array}$ & $\begin{array}{r}88.3 \\
+5.0\end{array}$ & $\begin{array}{r}77.8 \\
+4.4\end{array}$ & $\begin{array}{r}127.3 \\
+4.5\end{array}$ & $\begin{array}{r}121.9 \\
+4.5\end{array}$ & $\begin{array}{r}327.0 \\
+2.5\end{array}$ \\
\hline 3 & 12 & 7.1 & 3 & $\begin{array}{r}20.9 \\
+1.7\end{array}$ & $\begin{array}{r}331.4 \\
+8.9\end{array}$ & $\begin{array}{r}33.8 \\
\pm 2.8\end{array}$ & $\begin{array}{r}33.3 \\
\pm 2.8\end{array}$ & $\begin{array}{r}174.9 \\
\pm 6.7\end{array}$ & $\begin{array}{r}177.9 \\
\pm 8.0\end{array}$ & $\begin{array}{r}386.1 \\
\pm 3.6\end{array}$ \\
\hline 4 & 14 & 8.3 & 7 & $\begin{array}{r}95.3 \\
+3.4\end{array}$ & $\begin{array}{r}190.6 \\
\pm 8.6\end{array}$ & $\begin{array}{r}48.8 \\
\pm 2.7\end{array}$ & $\begin{array}{r}49.3 \\
\pm 2.8\end{array}$ & $\begin{array}{r}114.7 \\
\pm 4.4\end{array}$ & $\begin{array}{r}170.9 \\
\pm 8.2\end{array}$ & $\begin{array}{r}334.9 \\
\pm 3.2\end{array}$ \\
\hline 5 & 33 & 19.6 & 4 & $\begin{array}{r}203.9 \\
\pm 7.5\end{array}$ & $\begin{array}{r}389.3 \\
+8.7\end{array}$ & $\begin{array}{r}265.7 \\
\pm 8.1\end{array}$ & $\begin{array}{r}110.4 \\
\pm 3.9\end{array}$ & $\begin{array}{r}450.3 \\
+8.2\end{array}$ & $\begin{array}{r}298.0 \\
+9.4\end{array}$ & $\begin{array}{r}858.7 \\
+4.7\end{array}$ \\
\hline 6 & 12 & 7.1 & 3 & $\begin{array}{r}115.9 \\
+5.5\end{array}$ & $\begin{array}{r}167.4 \\
+5.3\end{array}$ & $\begin{array}{r}53.6 \\
\pm 4.5\end{array}$ & $\begin{array}{r}109.7 \\
+5.1\end{array}$ & $\begin{array}{r}86.8 \\
+5.3\end{array}$ & $\begin{array}{r}140.4 \\
+5.3\end{array}$ & $\begin{array}{r}336.9 \\
+3.0\end{array}$ \\
\hline 7 & 23 & 13.7 & 3 & $\begin{array}{r}217.6 \\
\pm 9.4\end{array}$ & $\begin{array}{r}290.4 \\
+9.3\end{array}$ & $\begin{array}{r}282.6 \\
\pm 9.9\end{array}$ & $\begin{array}{r}314.0 \\
+11.2\end{array}$ & $\begin{array}{r}315.4 \\
\pm 10.7\end{array}$ & $\begin{array}{r}161.2 \\
\pm 4.9\end{array}$ & $\begin{array}{r}790.6 \\
\pm 5.4\end{array}$ \\
\hline 8 & 7 & 4.2 & 3 & $\begin{array}{r}36.3 \\
+3.0\end{array}$ & $\begin{array}{r}142.6 \\
+6.7\end{array}$ & $\begin{array}{r}78.2 \\
+4.4\end{array}$ & 0 & $\begin{array}{r}113.7 \\
+5.0\end{array}$ & $\begin{array}{r}143.4 \\
+6.7\end{array}$ & $\begin{array}{r}257.1 \\
\pm 2.8\end{array}$ \\
\hline 9 & 22 & 13.1 & 6 & $\begin{array}{r}156.0 \\
\pm 7.1\end{array}$ & $\begin{array}{r}259.9 \\
\pm 10\end{array}$ & $\begin{array}{r}149.0 \\
\pm 3.8\end{array}$ & $\begin{array}{r}88.4 \\
+5.7\end{array}$ & $\begin{array}{r}239.4 \\
\pm 8.4\end{array}$ & $\begin{array}{r}237.1 \\
\pm 7.6\end{array}$ & $\begin{array}{r}564.9 \\
\pm 4.2\end{array}$ \\
\hline 10 & 23 & 13.7 & 6 & $\begin{array}{r}335.7 \\
+9.7\end{array}$ & $\begin{array}{r}133.5 \\
+5.7\end{array}$ & $\begin{array}{r}165.0 \\
\pm 7.9\end{array}$ & $\begin{array}{r}157.6 \\
\pm 6.2\end{array}$ & $\begin{array}{r}118.7 \\
+5.8\end{array}$ & $\begin{array}{r}357.9 \\
+10.5\end{array}$ & $\begin{array}{r}634.2 \\
+4.6\end{array}$ \\
\hline Means & 16.8 & - & $\begin{array}{r}4.5 \\
+0.5\end{array}$ & $\begin{array}{r}150.8 \\
\pm 30\end{array}$ & $\begin{array}{r}199.7 \\
\pm 37\end{array}$ & $\begin{array}{r}135.4 \\
\pm 28\end{array}$ & $\begin{array}{r}109.9 \\
\pm 28\end{array}$ & $\begin{array}{r}183.1 \\
\pm 37\end{array}$ & $\begin{array}{r}192.5 \\
\pm 25 \\
\end{array}$ & $\begin{array}{r}485.7 \\
\pm 67\end{array}$ \\
\hline Medians & & & & 137 & 178 & 119 & 98 & 123 & 166 & 378 \\
\hline C.V. & & - & -- & 0.63 & 0.58 & 0.66 & 0.80 & 0.64 & 0.42 & 0.44 \\
\hline
\end{tabular}


Table 3. Summary of seedbank germination (seedling emergence) data by species. Site numbers refer to list in Table I. Week of Germination is the number of weeks since the germination assay commenced the third week of March 2003. Mean site germination densities are given to show species preference under flooded and saturated substrate trials

\begin{tabular}{|c|c|c|c|c|c|}
\hline Species & $\begin{array}{c}\text { Site } \\
\text { Presenc } \\
\text { e } \\
\text { Freq. } \\
(\%) \\
\end{array}$ & $\begin{array}{l}\text { Germin. } \\
\text { Site }\end{array}$ & $\begin{array}{l}\text { Week of } \\
\text { Germin. }\end{array}$ & $\begin{array}{c}\text { Mean Site } \\
\text { Density } \\
\text { Flooded } \\
\text { Substrate } \\
\text { (seeds/m² } \\
\pm \text { S.E.) } \\
\end{array}$ & $\begin{array}{c}\text { Mean Site } \\
\text { Density } \\
\text { Saturated } \\
\text { Substrate } \\
\text { (seeds } / \mathbf{m}^{2} \\
\pm \text { S.E.) } \\
\end{array}$ \\
\hline $\begin{array}{l}\text { Eleocharis cellulosa } \\
\text { Torr. }\end{array}$ & 90 & $1-3,5-10$ & $\begin{array}{r}4,6,8,10,12,14 \\
16,18,20,24\end{array}$ & $110.0 \pm 1.2$ & $181.0 \pm 1.5$ \\
\hline Sagittaria lancifolia $\mathrm{L}$. & 70 & $1-5.8,9$ & $\begin{array}{r}4,6,8,10 \\
14,16 \\
\end{array}$ & $26.5+0.5$ & $19.1 \pm 0.4$ \\
\hline $\begin{array}{l}\text { Cladium jamaicense } \\
\text { Crantz }\end{array}$ & 60 & $1,6-10$ & $4,6,8,10,12$ & $9.4 \pm 0.4$ & $32.8+0.7$ \\
\hline $\begin{array}{l}\text { Rhynchospora tracyi } \\
\text { Britton }\end{array}$ & 50 & $3,4,6,9,10$ & $4,6,8,10$ & $2.6 \pm 0.1$ & $19.1 \pm 0.6$ \\
\hline $\begin{array}{l}\text { Utricularia purpurea } \\
\text { Walter }\end{array}$ & 30 & $1,4,5$ & $6,12,14,24,26$ & $14.5 \pm 0.6$ & $2.8 \pm 0.2$ \\
\hline Typha domingensis Pers. & 30 & $2,4,10$ & $4,6,14,16$ & $10.6 \pm 0.3$ & $5.3+0.2$ \\
\hline $\begin{array}{l}\text { Utricularia resupinata } \\
\text { B.D. Greene ex. } \\
\text { Bigelow }\end{array}$ & 30 & $7,9,10$ & $10,12,14,18$ & $16.6 \pm 0.4$ & $2.8 \pm 0.2$ \\
\hline $\begin{array}{l}\text { Bulbocystis ciliatifolia } \\
\text { (Elliott) Fernald }\end{array}$ & 20 & 1,4 & $6,8,10,14$ & $7.1 \pm 0.3$ & $5.7 \pm 0.2$ \\
\hline $\begin{array}{l}\text { Bacopa caroliniana } \\
\text { (Walter) B.L. Rob. }\end{array}$ & 20 & 9,10 & 10,18 & 0 & $4.9 \pm 0.2$ \\
\hline $\begin{array}{l}\text { Bacopa monnieri (L.) } \\
\text { Pennell }\end{array}$ & 20 & 4,10 & 6,8 & $2.3 \pm 0.1$ & $2.8 \pm 0.2$ \\
\hline $\begin{array}{l}\text { Polygonum } \\
\text { hydropiperoides Michx. }\end{array}$ & 10 & 2 & 6 & 0 & $3.3 \pm 0.2$ \\
\hline Utricularia biflora Lam. & 10 & 5 & 16 & $2.9 \pm 0.2$ & 0 \\
\hline Utricularia foliosa $\mathrm{L}$. & 10 & 1 & 8 & $3.8 \pm 0.2$ & 0 \\
\hline Totals & -- & -- & -- & $206.6 \pm 8.1$ & $279.7 \pm 13.6$ \\
\hline
\end{tabular}


Table 4. Mean germination densities by patch Side, Edge, and Site. The 13 species are ranked from high to low by site density. Coefficients of variation (C.V.) show a rather uniform absolute variation for Side and Edge densities by species . Densities $=$ seeds $/ \mathrm{m}^{2} \pm$ S.E.

\begin{tabular}{|c|c|c|c|c|c|c|c|}
\hline Species & $\begin{array}{l}\text { East } \\
\text { Side }\end{array}$ & $\begin{array}{c}\text { North } \\
\text { Side }\end{array}$ & $\begin{array}{l}\text { West } \\
\text { Side }\end{array}$ & $\begin{array}{c}\text { Outer } \\
\text { Edge } \\
(+1 \mathrm{~m})\end{array}$ & $\begin{array}{c}\text { Actual } \\
\text { Edge } \\
(0 \text { m) }\end{array}$ & $\begin{array}{c}\text { Inner } \\
\text { Edge } \\
(-1 \mathrm{~m})\end{array}$ & $\begin{array}{c}\text { Mean Site } \\
\text { Density }\end{array}$ \\
\hline & 98.6 & 116.2 & 75.9 & 66.2 & 120.8 & 103.7 & 290.7 \\
\hline Eleocharis cellulosa & \pm 1.7 & \pm 1.9 & \pm 1.5 & \pm 1.4 & \pm 1.9 & \pm 1.7 & +1.0 \\
\hline Sagittaria lancifolia & $\begin{array}{c}7.0 \\
\pm 0.4\end{array}$ & $\begin{array}{r}16.3 \\
+0.5\end{array}$ & $\begin{array}{r}22.5 \\
+0.8 \\
\end{array}$ & $\begin{array}{r}15.0 \\
\pm 0.7 \\
\end{array}$ & $\begin{array}{r}21.1 \\
\pm 0.7 \\
\end{array}$ & $\begin{array}{r}9.4 \\
+0.5 \\
\end{array}$ & $45.6 \pm 0.3$ \\
\hline Cladium jamaicense & $\begin{array}{c}6.0 \\
+0.5\end{array}$ & $\begin{array}{r}21.1 \\
+0.8\end{array}$ & $\begin{array}{r}15.1 \\
+0.6\end{array}$ & $\begin{array}{r}3.2 \\
+0.3\end{array}$ & $\begin{array}{r}11.5 \\
+0.6\end{array}$ & $\begin{array}{r}27.5 \\
+1.0\end{array}$ & $42.2+0.4$ \\
\hline Rhynchosp & 0 & $\begin{array}{r}16.6 \\
+0.8 \\
\end{array}$ & $\begin{array}{r}5.2 \\
+0.3 \\
\end{array}$ & $\begin{array}{r}2.6 \\
+0.2 \\
\end{array}$ & $\begin{array}{r}-2.3 \\
+0.2 \\
\end{array}$ & $\begin{array}{r}+16.8 \\
+0.8\end{array}$ & $21.7+0$. \\
\hline Utricularia 1 & $\begin{array}{c}7.2 \\
\pm 0.4 \\
\end{array}$ & $\begin{array}{r}5.6 \\
+0.3 \\
\end{array}$ & $\begin{array}{r}6.7 \\
+0.4 \\
\end{array}$ & $\begin{array}{r}7.9 \\
+0.5 \\
\end{array}$ & $\begin{array}{r}3.2 \\
+0.3 \\
\end{array}$ & $\begin{array}{r}8.3 \\
\pm 0.4 \\
\end{array}$ & $19.4 \pm 0.2$ \\
\hline Utricularia & $\begin{array}{c}2.8 \\
+0.2 \\
\end{array}$ & $\begin{array}{r}+0.5 \\
+0.8 \\
\end{array}$ & $\begin{array}{r}+0.7 \\
+0.8 \\
+0.4 \\
\end{array}$ & 10.0 & $\begin{array}{r}+4.8 \\
+0.4 \\
\end{array}$ & $\begin{array}{r}-12.6 \\
+0.8 \\
\end{array}$ & $17.3 \pm 0$. \\
\hline Typha domir & $\begin{array}{r}11.7 \\
\pm 0.5 \\
\end{array}$ & $\begin{array}{r}4.3 \\
\pm 0.3 \\
\end{array}$ & 0 & $\begin{array}{r}6.8 \\
+0.3 \\
\end{array}$ & $\begin{array}{r}6.4 \\
+0.4 \\
\end{array}$ & $\begin{array}{r}2.8 \\
+0.2 \\
\end{array}$ & $16.0 \pm 0.2$ \\
\hline Bulbocystis ciliatifolia & $\begin{array}{c}2.5 \\
\pm 0.2 \\
\end{array}$ & $\begin{array}{r}7.8 \\
+0.5 \\
\end{array}$ & $\begin{array}{r}2.4 \\
+0.2 \\
\end{array}$ & $\begin{array}{r}3.2 \\
+0.3 \\
\end{array}$ & $\begin{array}{r}4.6 \\
+0.4 \\
\end{array}$ & $\begin{array}{r}4.9 \\
+0.3 \\
\end{array}$ & $12.7 \pm 0.2$ \\
\hline Bacopa monnieri & $\begin{array}{c}5.1 \\
+0.3 \\
\end{array}$ & 0 & 0 & 0 & $\begin{array}{r}2.3 \\
+0.2 \\
\end{array}$ & $\begin{array}{r}2.8 \\
+0.2\end{array}$ & $5.1+0.1$ \\
\hline Bacopa caroliniana & 0 & $\begin{array}{r}2.1 \\
+0.2 \\
\end{array}$ & $\begin{array}{r}2.8 \\
+0.2 \\
\end{array}$ & $\begin{array}{r}2.1 \\
+0.2 \\
\end{array}$ & $\begin{array}{r}2.8 \\
+0.2 \\
\end{array}$ & 0 & $4.9 \pm 0.1$ \\
\hline Utricularia foliosa & $\begin{array}{c}3.9 \\
+0.3\end{array}$ & 0 & 0 & 0 & 0 & $\begin{array}{r}3.9 \\
+0.3\end{array}$ & $3.9 \pm 0$. \\
\hline $\begin{array}{l}\text { Polygonum } \\
\text { hydropiperoides }\end{array}$ & $\begin{array}{c}3.3 \\
+0.3\end{array}$ & 0 & 0 & 0 & $\begin{array}{r}3.3 \\
+0.3\end{array}$ & 0 & $3.3+0.1$ \\
\hline Utricularia biflora & $\begin{array}{c}2.9 \\
\pm 0.2 \\
\end{array}$ & 0 & 0 & $\begin{array}{r}2.9 \\
+0.2 \\
\end{array}$ & 0 & 0 & $2.9 \pm 0.1$ \\
\hline $\begin{array}{l}\text { Mean Spp. } \\
\text { Germinations by Site }\end{array}$ & $\begin{array}{r}11.6 \\
\pm 7.3\end{array}$ & $\begin{array}{r}15.4 \\
\pm 8.6\end{array}$ & $\begin{array}{r}10.4 \\
\pm 5.8\end{array}$ & $\begin{array}{r}8.5 \\
\pm 5.0\end{array}$ & $\begin{array}{r}14.1 \\
\pm 9.0\end{array}$ & $\begin{array}{r}14.8 \\
\pm 7.7\end{array}$ & - \\
\hline C.V.spp. & 2.3 & 2.0 & 2.0 & 2.1 & 2.3 & 1.9 & - \\
\hline
\end{tabular}


Table 5. Total mean Site seed densities for nested categories in the 10 sawgrass patch sites.

Each Side was divided into 3 Sides, East, North, and West. These 3 Sides were then divided into 3 Edge distances. Densities $=$ seeds $/ \mathrm{m}^{2} \pm$ S.E.

\begin{tabular}{|c|c|c|c|c|}
\hline \multirow[t]{2}{*}{ SIDE \& EDGE } & \multicolumn{3}{|c|}{ PATCH EDGE MEANS } & \multirow{2}{*}{$\begin{array}{c}\text { SIDE } \\
\text { MEANS }\end{array}$} \\
\hline & Outer (+1m) & Edge (0m) & Inner (-1m) & \\
\hline EAST & $29.2 \pm 2.2$ & $60.5 \pm 4.0$ & $61.1 \pm 4.0$ & $150.8 \pm 29$ \\
\hline NORTH & $47.9 \pm 3.7$ & $85.4 \pm 4.3$ & $66.7 \pm 4.5$ & $199.7 \pm 37$ \\
\hline WEST & $33.3 \pm 3.6$ & $37.3 \pm 3.0$ & $64.8 \pm 3.5$ & $135.4 \pm 28$ \\
\hline EDGE MEANS & $109.9 \pm 28$ & $183.1 \pm 37$ & $192.5 \pm 25$ & $\begin{array}{c}\text { SITE } \\
\text { DENSITY } \\
485.7 \pm 67\end{array}$ \\
\hline
\end{tabular}


Table 6. Summary of nested ANOVAs for seedling emergence from soil samples taken around sawgrass patches in Shark River Slough, ENP. The contributions of listed variables to the overall variation in seed germination (seedling emergence) were determined. $*=$ significant at $95 \%$ level.

\begin{tabular}{|llll|}
\hline SOURCE OF VARIATION & & & \\
& & & \\
& & & \\
& & & \\
& & & \\
& & & \\
Site & $9,10.9$ & 1.52 & 0.253 \\
Side & 2,18 & 0.621 & 0.549 \\
Edge & 2,18 & 5.58 & $0.013^{*}$ \\
Hydrology & 1,304 & 0.227 & 0.634 \\
Trial & 1,304 & 2.53 & 0.113 \\
Site x Side & 18,304 & 1.70 & $0.038^{*}$ \\
Site $x$ Edge & 18,304 & 0.760 & 0.746 \\
Side x Edge & 4,304 & 1.09 & 0.362 \\
\hline
\end{tabular}


Table 7. Summary of diaspore assay analysis from 25 randomly selected soil samples.

The diaspore assay lists only intact diaspores (visibly complete) by mean density (seeds $/ \mathrm{m}^{2} \pm$ S.E.). Intact diaspores were counted from a subsample $(100 \mathrm{ml})$ of the soil used for germination assays (not tray soil of post germination assay). For comparison, the germination assay data is given for the same 25 soil samples, right. Small seed size and lack of hard seed coat probably accounts for the lack of other than the three listed species being found in the visual count.

\begin{tabular}{|l|r|r|}
\hline & $\begin{array}{c}\text { Mean Intact } \\
\text { Diaspore Assay } \\
\text { Density }\end{array}$ & $\begin{array}{c}\text { Mean } \\
\text { Germination } \\
\text { Assay Density }\end{array}$ \\
\hline Species encountered as intact seeds \\
Cladium jamaicense & & $6.7 \pm 3.4$ \\
Eleocharis cellulosa & $210.0 \pm 50$ & $36.4 \pm 10.2$ \\
Rhynchospora tracyi & $75.6 \pm 51$ & $1.1 \pm 1.1$ \\
\hline Species only in seedling analysis & $84.6 \pm 36$ & $3.1 \pm 8.5$ \\
Sagittaria lancifolia & & $2.4 \pm 1.7$ \\
Typha domingensis & --- & $3.0 \pm 2.2$ \\
Utricularia purpurea & -- & $2.4 \pm 1.7$ \\
Utricularia resupinata & -- & $1.1 \pm 1.1$ \\
Other species & & $\mathbf{9 ( 3 6 \% )}$ \\
\hline Samples with no seeds in analysis & $\mathbf{8 ( 3 2 \% )}$ & $\mathbf{5 6 . 3} \pm \mathbf{1 3}$ \\
\hline Total Mean Density & $\mathbf{3 7 0 . 1} \pm \mathbf{8 2}$ & \\
\hline
\end{tabular}


Table 8. Predicted hydrochorous dispersal distances of diaspores with different masses. The law of momentum $\left(\mathrm{m}_{1} \mathrm{v}_{1}=\mathrm{m}_{2} \mathrm{v}_{2}\right)$ is used with Hibiscus grandiflora as the reference species $\left(\mathrm{m}_{1} \mathrm{~V}_{1}\right)$ for computing potential velocity of other taxa $\left(\mathrm{v}_{2}\right) . \mathrm{FD}_{50}=$ the days for $50 \%$ of tested seeds to sink. Mean seed mass was computed from 25 or more seeds from at least three plants.

\section{SPECIES MEAN MASS VELOCITY BUOYANCY}

$(\mathrm{mg} /$ diaspore $) \quad(\mathrm{cm} / \mathrm{sec}) \quad\left(\mathrm{FD}_{50} \underline{0}\right)$ days

\section{A. By Species:}

$\begin{array}{lccr}\text { Sagittaria lancifolia } & 1.0 & 24.4^{*} & 4 \\ \text { Rhynchospora tracyi } & 1.9 & 13.2^{*} & 3 \\ \text { Cladium jamaicense } & 2.7 & 9.0^{*} & 12 \\ \text { Hibiscus grandiflora }\left(\mathbf{m}_{\mathbf{1}} \mathbf{v}_{\mathbf{1}}\right) & \mathbf{8 . 1} & \mathbf{3 . 0} & \mathbf{3} \\ \text { Rhynchospora inundata } & 13.7 & 1.8 & 30 \\ \text { Chrysobalanus icaco } & 547 & 0.04 & 30\end{array}$

\section{B. Within A Species: sawgrass}

(Data from Chapter III)

$\begin{array}{llr}\text { Lowest mass to germinate } & 1.1 & 22.2^{*} \\ \text { Largest mass to germinate } & 5.8 & 4.2 *\end{array}$

\section{By Life Form:}

$\begin{array}{lrcr}\text { Graminoids } & 0.8 \text { (median) } & 29.0^{*} & 3 \text { (median) } \\ \text { Forbs } & 3.9 \text { (median) } & 6.3^{*} & 15 \text { (median) } \\ \text { Woody Temperate } & 18.4 \text { (median) } & 1.3 & 4 \text { (median) }\end{array}$

\footnotetext{
* As the velocity exceeds $3.0 \mathrm{~cm} / \mathrm{sec}$, friction by the viscosity of water and plant stem interference, begins to cause turbulence, slowing diaspore movement (Leonard et al. 2006). Additionally, the shape of the diaspore can also influence hydrochory dynamics. The higher velocities listed are therefore not realized. Surface matter, such as dead plant litter, algal mats, and Utricularia spp., also impede the surface movement of materials, i.e., diaspores (Leonard et al 2006). Changes in wind velocity and direction across the water surface will also contribute to diaspore velocity (fetch dynamics) .
} 


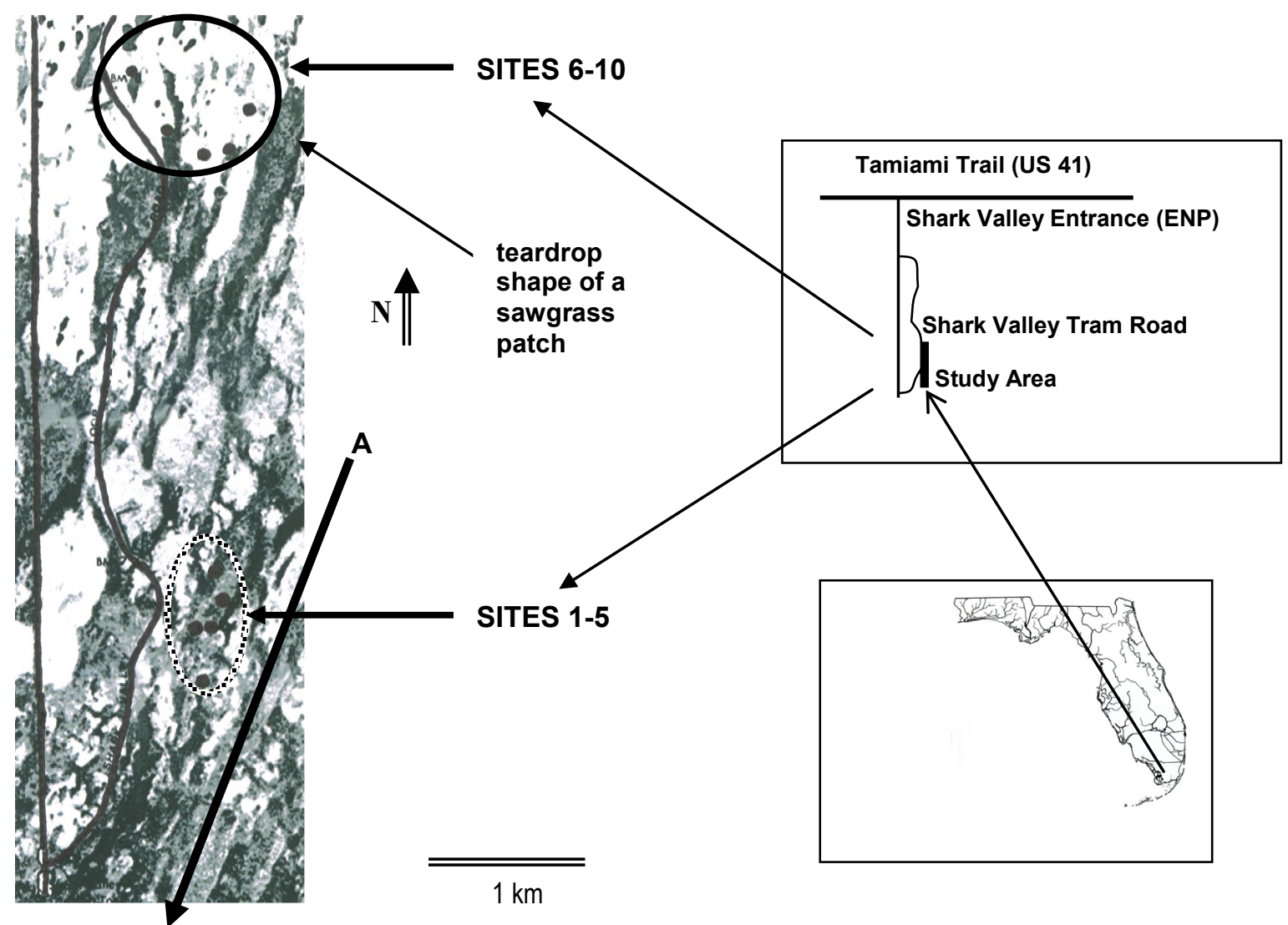

Figure 1. Location of study areas in the NW edge of Shark River Slough, ENP. An aerial view (left) shows the sampling area vegetation pattern, patch orientation, and prevailing flow direction $\left(\mathrm{A}=20^{\circ}\right)$. Only one sawgrass patch has the historic "teardrop" shape. The exact date of the photograph is unknown but predates this 2003 study by a few years (Topozone.com). 


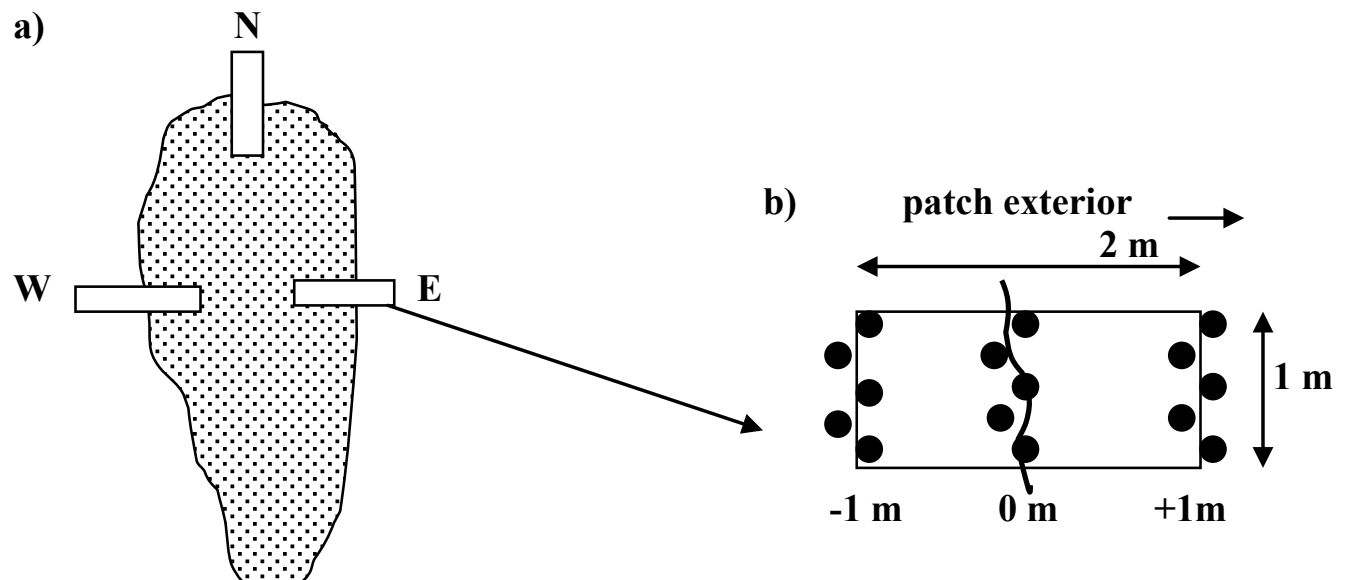

Figure 2. Sampling details of soil from sawgrass patches. a) General location of edge sampling at each of 10 sawgrass patches. b) Detail of soil sampling at E, N, and $\mathrm{W}$ edges. Each circle represents $500 \mathrm{~cm}^{3}$ of soil. $0 \mathrm{~m}=$ actual edge of sawgrass patch. The nested sampling was thus $5-500 \mathrm{~cm}^{3}$ soil samples (combined into one $2,500 \mathrm{~cm}^{3}$ sample) from each of three edge transects $(-1 \mathrm{~m}, 0 \mathrm{~m},+1 \mathrm{~m}) \times 3$ sides of each patch $(\mathrm{E}, \mathrm{N}, \mathrm{W}) \times 10$ patches $=90$ samples. 


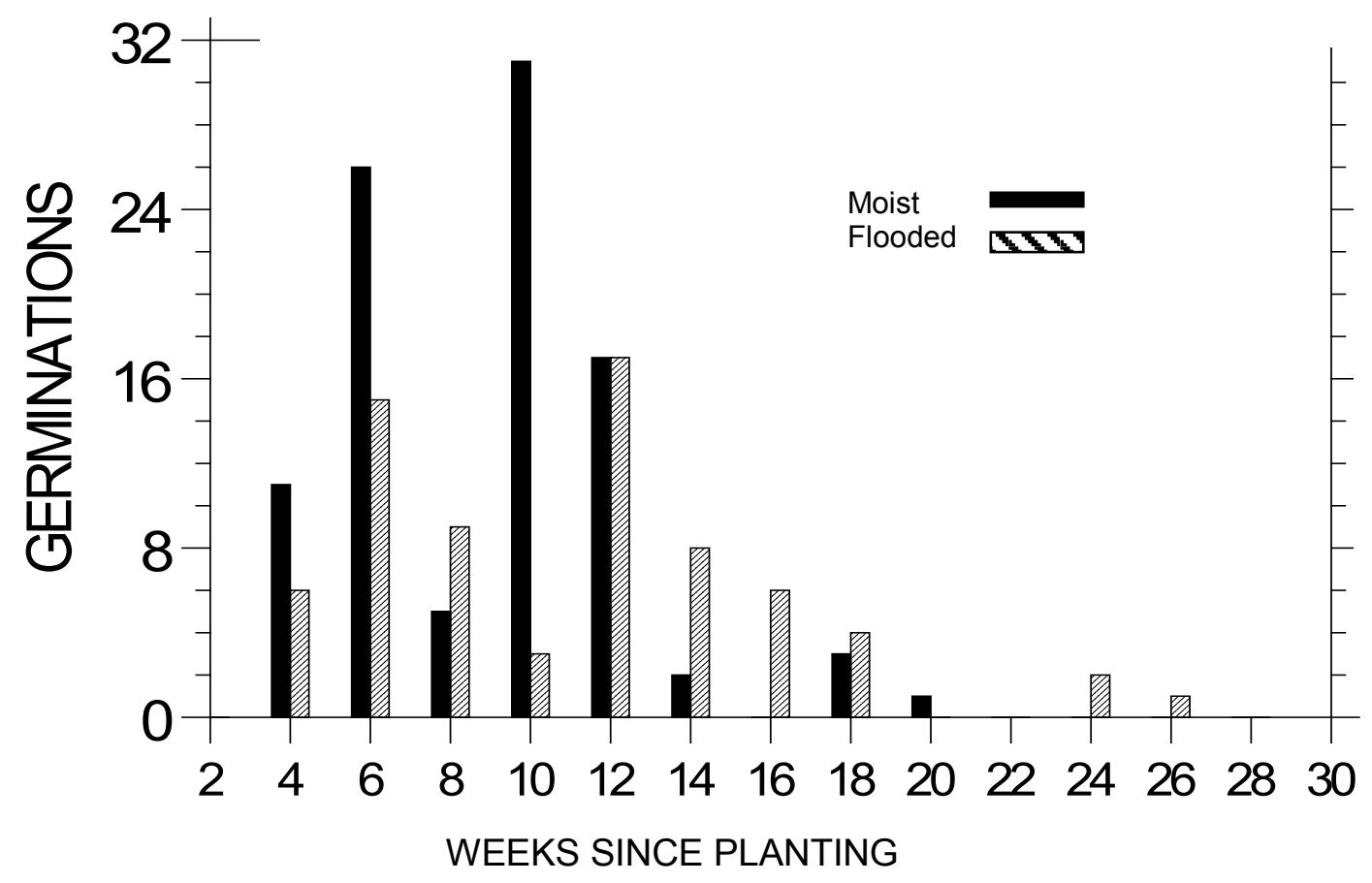

Figure 3. Germinations by hydrology treatment. Weeks represents time since the experiment began, $3^{\text {rd }}$ week of March 2003. Note that germinations from moist substrate dominated in the early weeks. 


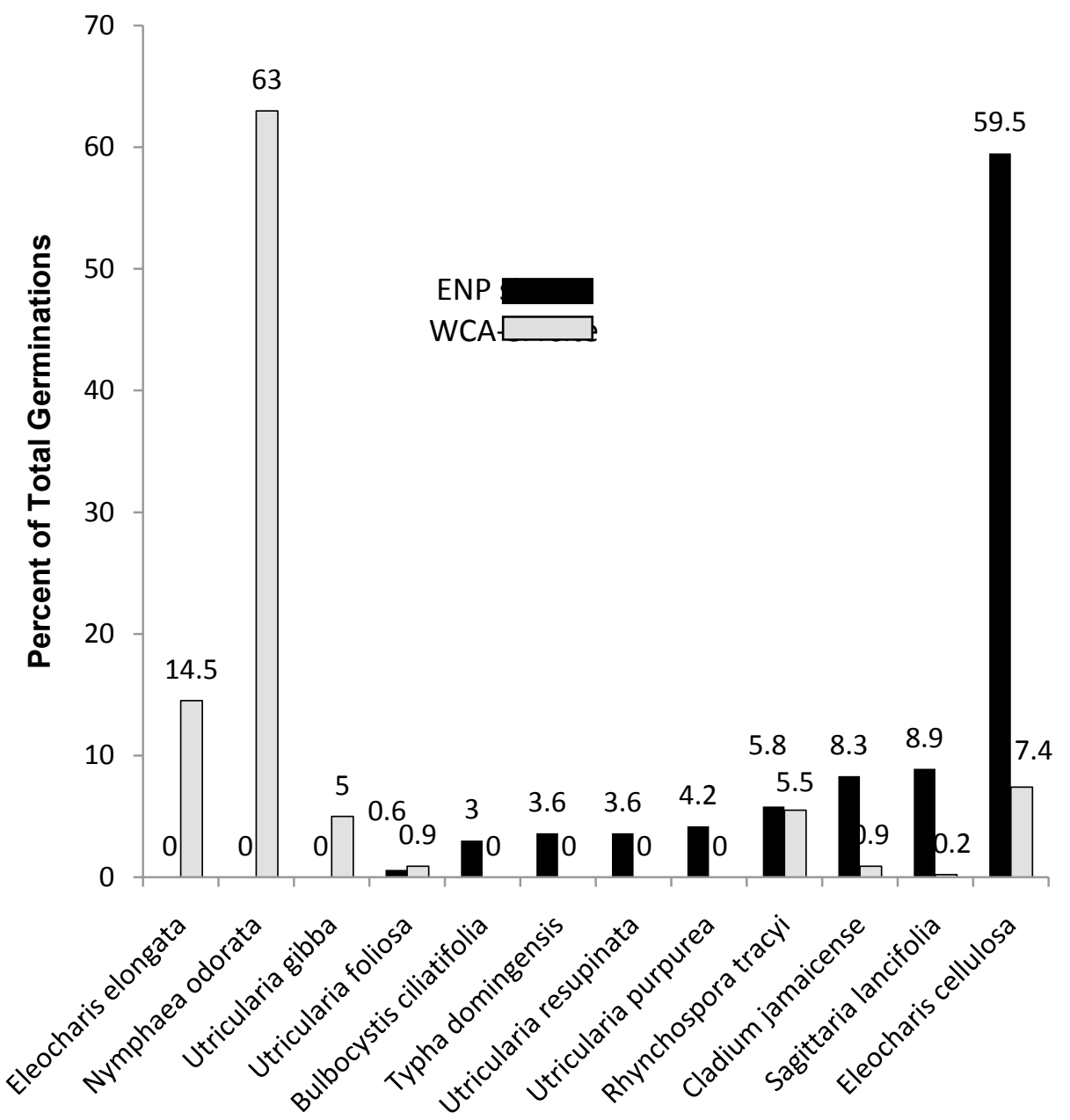

Species With 5+ Germinations, Ranked Low to High at ENP

Figure 4. Comparison of the ENP seedbank species composition with a study done a few $\mathrm{km}$ north in flooded WCA-3A (J. H. Richards and S. Coyne unpublished data 1997). Only Angiosperms with at least five germinations per species are included. The two WCA-3A species at far left are common in longer flooded areas, while the two species (ENP) at far right are common in less flooded (shorter hydroperiod) areas. 


\section{CHAPTER IV}

\section{FRUIT SIZE AND GERMINATION PROBABILITY IN THE DOMINANT PLANT OF THE EVERGLADES, Cladium jamaicense Crantz}

\section{SAWGRASS ABSTRACT}

Seeds can vary in size with respect to location within an infructescence, as well as among plants, and within and between sites. Using a nested design, I evaluated fruits of sawgrass (Cladium jamaicense Crantz) from three different infructescence locations among five plants collected from each of ten sites in the Everglades. The fruits were tested for variation in fruit size, seed germination ability, and potential viability by site, among plants, and among locations within the infructescence. Fruit mass, fruit length, germination and potential seed viability were all significantly influenced by site and by covariation of site with individual plants $(p \leq 0.050)$.

Fruit mass had a normal distribution (mean $2.7 \mathrm{mg}$ ), but germination ability and potential seed viability were greater among larger fruits. The germination rate was low $(17.9 \%)$, and the proportion of potentially viable ungerminated seeds was even lower (4.0\%). The germination study took place under ambient conditions that coincided with the seasonal Everglades dry-down and consequent winter temperature fluctuations.

KEY WORDS: sawgrass, germination, Everglades, seed size

\section{INTRODUCTION}

Environmental factors and maternal influences affect seed formation, maturation, and germination ability (Gutterman 1992). Seed mass may, for example, vary by a factor of five within a population, and this variation can be found within an infructescence or among fruits sampled at the same location in an infructescence but at different times of the same or different

years (Fenner 1985; Baker 1972). Seed mass can also vary among individual plants at the same 
or different sites. This study evaluates variation in fruit size, germination ability, and seed viability of sawgrass by site, plant, and position in the infructescence.

A number of environmental factors are known to affect seed development. Seeds may be smaller when they develop under higher temperatures, when maternal nutrient levels are low, when they form in low light conditions, at greater altitudes, and/or during droughts or shorter growing seasons (Baker 1972; Fenner and Thompson 2005). Other environmental factors affecting seed development include day length during seed development, light quality, phosphorus levels, and temperature changes during seed maturation (Somers and Grant 1981; Gutterman 1992). Especially among perennial species (Cardel 2004), seeds may also be smaller or fewer in number when leaf area is lost to herbivory (Koptur et al. 1996). In general, seed size is inversely related to latitude and altitude (Baker 1972; Moles and Westoby 2003).

In terrestrial plants, variation in germination ability has been documented within the infructescence of the same plant, as well as among plants whose seeds matured under different environmental conditions (DeViana 1999; Fenner and Thompson 2005). These environmental influences modify the germination ability of seeds by changing seed coat thickness (Fenner and Thompson 2005), polyphenyl content (low phosphorus increases polyphenyls, which decreases germination ability) (Gutterman 1992), seed coat permeability (Fenner and Thompson 2005), and seed coat resistance to fungi (Gutterman 1992). Seed set and seed size have also been found to be resource limited (Fenner and Thompson 2005).

In the oligotrophic Everglades, symbiotic arbuscular mycorrhizal fungi (AMF) are important in nutrient cycling. Sawgrass have AMF (Jayachandran and Shetty 2003). This relationship with sawgrass roots transfers phosphorus from soil (most effectively from peat) to sawgrass tissue and is possibly a factor in seed development, since increased $\mathrm{P}$ decreases sawgrass germination (Jayachandran and Shetty 2003; Johnson 2004). 
Maternal influences known to affect seed development include location of seed within the plant infructescence (largest seeds are frequently found proximally), age of the parent plant, and position of seeds within the fruit (Gutterman 1992, Jakobsson and Eriksson 2000).

Variations in germination timing, brought about by maternal seed provisioning and environmental cueing, are thought to provide the best survival strategy by spreading germination over time. This variation is especially important in disturbance-prone environments (Fenner and Thompson 2005) such as the Everglades.

Sawgrass is a dominant perennial sedge that covers about $70 \%$ of the Everglades, and additionally ranges from Virginia west to Texas and south throughout the Caribbean isles to Peru (Loveless 1959; Stewart and Ornes 1975; Godfrey and Wooten 1981). Although it primarily reproduces asexually by rhizomes and dormant basal buds, and rarely by plantlets produced erratically within the inflorescence (Miao et al. 1998), sawgrass also produces seeds (Brewer 1996). Ivey and Richards (2001) determined that sawgrass throughout the Everglades has a relatively low genetic diversity, showed no significant variation among water management units, and exhibited a 40,000:1 ratio of clonality to seed success.

In this study, I evaluated sources of variability in sawgrass fruits. Sawgrass fruits are achenes, so one fruit produces one seed. Thus fruit variability is directly related to variation in seeds. Fruits from different sites, from different plants, and from different parts of individual plants were compared with a nested design to determine if they caused any significant variation in fruit size and germination. Remaining ungerminated seeds were sectioned to assess what proportion was filled with endosperm and thus were possibly viable but dormant.

\section{MATERIALS and METHODS}

\section{a. Fruit sources and climate}

Within the Koppen system of climate classification, South Florida is a tropical wet-dry savannah (Aw) with an average temperature each month $>17^{\circ} \mathrm{C}\left(64^{\circ} \mathrm{F}\right)($ Strahler and Strahler 
1998). The annual average temperature is $24^{\circ} \mathrm{C}\left(75^{\circ} \mathrm{F}\right)$, with January the coldest month. The annual rainfall across the Everglades is $137-163 \mathrm{~cm}(54-64$ in.) (Henry et al. 1994).

Fruits were collected between 8 and 16 August 2005 at 10 sampling sites in five geographic areas (Table 1, Fig. 1). Site 1 was on the shore of a campus lake at Florida International University; Sites 2, 8, 9, and 10 were along Levee 67 in WCA-3A north of US 41 in Shark River Slough; Site 3 was in the central area of WCA-3A; Sites 4 and 5 were along the shore of the eastern drainage canal for the Big Cypress Swamp near US 41; Sites 6 and 7 were about three miles south of Florida City on the western and eastern sides, respectively, of US 1 in marl prairies of the Everglades (Table 1, Fig. 1). The sites were chosen for their diverse hydrologic conditions as well as accessibility.

\section{b. Achene sampling and analysis}

At each sampling site, infructescences were collected from the culms of five different plants. Fruit from each of three locations on the infructescence (lower, mid, and upper) were bagged separately and labeled by infructescence location, plant, and site.

In the laboratory, 25 fruits from the lower, middle, and upper part of each infructescence were threshed from plant fragments. This protocol led to the collection of 3 units of 25 fruit samples from each of five plants at each of the 10 sites, or a total of 3,750 fruits. Individual fruits were weighed $(\mathrm{mg})$ to three significant digits and their lengths measured to the nearest $0.5 \mathrm{~mm}$. They were then placed individually in separate cells ( 1 ” deep x 9/16" wide) of standard nursery seed trays with the 3,750 fruits randomized into 25 blocks of 150 fruits per block. The lower half of each cell was filled with peat-based nursery mix and the top half with silica sand. Fruits were positioned about $0.5 \mathrm{~cm}$ deep in the sandy, upper half of the cells. The nursery trays were then placed on benches in a shade house covered with clear plastic (to regulate heavy precipitation) and screened sides (to allow for ambient conditions), from 27 
November 2005 to 19 March 2006 (16 weeks). Twice daily the trays received fine droplet overhead irrigation. Germinations were recorded weekly and removed.

At the end of four months, the ungerminated seeds were sectioned and examined microscopically to determine if the seeds were filled with parenchymatic endosperm (potentially viable) or dry and shrunken (non-viable). The seeds with parenchymatic endosperm were considered potentially able to germinate, but not yet cued to do so (Lippitt and Moran 1993).

The germination study took place under outdoor ambient conditions that coincided with the annual Everglades dry-down and winter temperature fluctuations (November - February). These conditions are known to cue sawgrass germinations (Lorenzen et al. 2000; Leck and Schutz 2005; personal observations). Two significant cold snaps, with night temperatures $<7^{\circ}$ C, occurred during the germination study.

Significant variation of fruit mass, fruit length, seed germination, and viable (ungerminated) seeds caused by site, plant, infructescence location, and by interactions among these three were analyzed with nested ANOVA that accommodated fixed and random variables. Germination and seed viability data were arcsine $(\operatorname{SqRt}(($ observed +0.375$) / 25.75))$ transformed before analysis to convert binary data into proportions for appropriate data processing. Germinated seed was compared with potentially viable seed by paired t-testing to evaluate variation between these two groups by fruit size. The 25 blocks of randomized seeds within germination trays were evaluated for any significant variation in germination and seed viability (at the 0.05 level) with ANOVA. SYSTAT 8.0 Software (SPSS 1997) was used for all analyses.

\section{c. Buoyancy testing}

Sawgrass fruits were harvested from three or more plants and sorted by mass into two groups of 100 fruits each. One group had small fruits $(\leq 2.5 \mathrm{mg})$, while the other had large 
fruits ( $>2.5 \mathrm{mg})$. Each unit of 100 fruits was divided into two 50 -fruit units to provide a replicate treatment. The four 50-fruit units were placed in separate containers of water and monitored daily for continued flotation. Average buoyancy for the 50-fruit units were quantified by the percent of fruit floating after 60 days. At the cessation of the experiment, all seeds were sectioned to determine the probable viability, according to Lippitt and Moran (1993).

\section{RESULTS}

\section{a. Fruit size and germination}

Of the 3,750 fruits that began the germination experiment, 50 fruits were lost to dislodging during rainstorms, leaving 3,700 to be evaluated for their germination ability. The fruit mass distribution $(\mathrm{N}=3,700)$ was nearly normal (Fig. 2). The overall fruit mass mean was $2.7 \pm 0.9$ $\mathrm{mg}$, with a median of $2.6 \mathrm{mg}$ (Table 2a). The results of nested ANOVA testing shows significant variation only in Site $(p<0.050)$ and the interaction of Site $\mathrm{x}$ Individual Plant $(=$ Plant nested within Site $)(p<0.001)$. Fruit location within sawgrass infructescences-upper, middle, lower — did not significantly influence fruit mass or fruit length (Tables $2 b, 3$ ).

\section{3b. Germination and viability patterns}

After 16 weeks, 664 seeds (17.9\%) germinated from the 3,700 fruits (Table 2a).

Between 3 and 5 weeks, there was an initial spike of 380 germinations (Fig. 3a). Two smaller peaks followed, each occurring 3 - 4 weeks after several hours of low temperatures (below $45^{0}$ $\mathrm{F}=7.2^{0} \mathrm{C}$ ) for one night. These latter two peaks occurred at week 8 and week 15 of the 16 week experiment. The large initial peak represented $57 \%$ of all germinations, while the smaller peaks represented $16 \%$ and $9 \%$, respectively (Fig. 3a). The germination pattern for seeds less than the mean mass, $2.7 \mathrm{mg}$, matched that of seeds greater than the mean mass (Fig. 3b).

The rate of germinations decreased over the first 10 weeks of the 16-week study (Fig.

4). The mean fruit weights for weekly seed germination totals ranged between $3.0-3.8 \mathrm{mg}$ 
(Fig. 5). The mean fruit mass of germinating seeds decreased over the first 10 weeks of the study (Fig. 5).

Only 146 of the 3,036 ungerminated seeds possessed parenchymatic endosperm upon sectioning and were thus potentially viable. This represented only $4.8 \%$ of the ungerminated seeds or $4.0 \%$ of all 3,700 seeds studied. The total potentially viable seeds added to germinated seeds was 810 seeds (21.9\% of the total) (Table $2 a)$. The mean fruit mass for germinated seeds $(\mathrm{N}=664)$ was $3.5 \pm 0.7 \mathrm{mg}$ (median $=3.5 \mathrm{mg})$, and the mean fruit mass for potentially viable seeds $(\mathrm{N}=146)$ was $3.7 \pm 0.8 \mathrm{mg}($ median $=3.7 \mathrm{mg})($ Figs. $6 \mathrm{a}, 6 \mathrm{~b})$.

Germinations and viable seeds from the three regions of infructescences were nearly evenly divided - about one-third per region (Table $2 b$ ). Even though the upper region produced the most germinations and remaining viable seeds (Table $2 b$ ), the differences were not statistically significant at the $p=0.05$ level. Potential viability, likewise, did not vary significantly by infructescence location $(p=0.695)$ (Table 3$)$.

Germination and potential viability by site was significant $(p<0.050)$ and interaction of Site $\mathrm{x}$ Individual Plant was significant $(p<0.001)$. Sites 2,3 , and 6 had $>100$ germinations by site, but Sites 4 and 5 had fewer than 8/site. The site range for germinations ranged from 5 to 150 (Table 2a). The median for site germinations was 53.5 seeds, while the median for potentially viable seeds was only 7.5 seeds (Table $2 a$ ). In a breakdown of germinations by site into mass categories, some sites had notably more germinations among small seeds, e.g. sites 2 and 6, while germinations among large seeds were more prevalent in other sites, e.g. sites 1, 3, 9 (Table 4).

\section{3c. Fruit buoyancy and potential viability}

The flotation experiment was terminated at 66 days, although $100 \%$ of seeds with a mass $>2.5 \mathrm{mg}$ continued to float, and the majority of seeds with a mass $\leq 2.5 \mathrm{mg}$ remained floating. However, when the seeds were sectioned, the two mass categories differed 
significantly by potential viability; $48 \%$ of the larger seeds were potentially viable compared to only $3 \%$ of the smaller ones.

\section{DISCUSSION}

Only $17.9 \%$ of seeds germinated throughout the 16 -week study, and $4.0 \%$ of nongerminated seeds were potentially viable but possibly not cued to germinate. Germinated seeds added to potentially viable seeds totaled $22.0 \%$ of the 3,700 seeds tested. However, the low level of germination is compatible with the range of four other dominant Everglades species, with $16 \%$ to $29 \%$ germination (Sutton 1993; Ponzio et al. 1995). The wide range in germinations ( 5 to 150 out of 375 per site; Table $2 a$ ) observed among sites is one of the most common variations found among collected seeds (Baskin and Baskin 2001; Fang et al. 2004). Germinations, potentially viable seeds, fruit mass, and fruit length varied significantly by Site and Site x Individual Plant $(p<0.050)$ (Table 3). Variations in hydroperiod and depth of substrate may contribute to the greater variation among site and individual plants. Where substrate is deeper, the hydroperiod would be longer and the nutrient build up greater from a longer hydroperiod. The longer hydroperiod would result in more peaty buildup and faunal nutrient additions (J. Trexler personnal communication). The evaluation of these nested ecosystems must be further studied.

Why were only one-fifth of seeds viable by germination or potentially viable and dormant? Gutterman (1992) suggests the following potential causes of reduced viability: 1) inbreeding depression; 2) lack of appropriate maternal provisioning of seeds due to changing environmental cues; and 3) pathogenic causes, especially fungi. Daehler and Strong (1994) suggested that inbreeding depression was a possible factor contributing to the large variability of reproductive output in a study of clones of Spartina alterniflora. Snyder and Richards (2005) also noted that sawgrass can self-fertilize, although the sexes within an inflorescence are usually temporally separated. Ivey and Richards (2001) have found a rather uniform genetic 
structure in sawgrass throughout the Everglades water conservation areas. Inbreeding may be supported by their observations as the cause for the low number of germinations and the low number of remaining potentially viable seeds.

Montalvo (1994) observed that self-pollination can produce a smaller seed size than that produced by cross-pollination. Both crossing and selfing may occur in sawgrass populations in response to such factors as clone size, number of ramets, and timing of flowering (Snyder and Richards 2005). Variations in seed mass for selfed and out-crossed seeds of sawgrass are unknown for sawgrass, but seed mass of selfed seed is known to be smaller in some native species (Pinto-Torres and Koptur 2009).

In general, large fruits held seeds with greater germination ability than did small fruits (Figs. 5, 6a). Small seeds have greater dispersal ability as they move at faster rates and to larger distances according to the seed adaptability model of Venable and Brown (1988); however, these small seeds have a lower establishment probability than large seeds. In this study, for example, few germinations occurred among sawgrass fruits less than the overall $2.7 \mathrm{mg}$ mean mass (Table 4).

In addition, small seeds have been found to germinate sooner than large seeds on wet sand (Gutterman 1992; Baskin and Baskin 2001; Fang et al. 2004). In the current study, however, small sawgrass seeds did not germinate sooner than large sawgrass seeds throughout the 16-week study (Fig. 3b).

Germinations from small seeds in this study occurred synchronously with large seed germinations (Fig. 3b). The mass range by site was 1.1 to $5.8 \mathrm{mg}$ (Table 4). The different dispersal capabilities of sawgrass should therefore be broad since hydrochorous dispersal capabilities are size-dependent—small seeds can disperse farther than large seeds (Venable and Brown 1988). This dual strategy, of small seeds for distant areas and large seeds for local 
population continuance, is generally thought to broaden the dispersal range and thus improve the odds for species survival.

Overall, only $11.6 \%$ of germinations were from seeds of fruit smaller than the overall mean mass for fruit, but, of all sites, Site 6 was unique by the large number of small seeds that germinated (Table 4). In sites with longer hydroperiods, e.g., Site 3, the seed mass distribution of germinations is shifted right to larger seeds (Table 4). The dual germination pattern, by variation in hydrology, suggests that ecological trait filtration may favor greater colonization ability in harsh, short hydroperiod sites by selecting for greater germinations of small seeds and favor germinations of large seeds in long hydroperiod sites. However, more study is needed that evaluates the relationship with hydroperiod and seed size.

Because the complete development of seeds varies greatly by site and year, due to environmental factors (Fenner and Thompson 2005; Sutton 1993; Jakobsson and Eriksson 2000), phosphorus availability may be a significant factor explaining variation in seed germination by site. Fertilizer treatments with N, P, and $\mathrm{K}$ have been shown to produce seeds with different germination percentages (Leeds et al. 2006; Gutterman 1992; Johnson 2004). In the oligotrophic Everglades ecosystem, significant increases in flooding elevate nutrient accumulation in plants (Newman et al. 1996), and increases in nutrients - especially phosphorus - can affect seed development (Gutterman 1992). Fires, common in April and May, release additional nutrients in fly ash that are quickly absorbed from water by sawgrass (Stewart and Ornes 1975).

Seed germination occurs as a result of genetically-based responses to cueing by both the amplitude and number of temperature changes. Large temperature fluctuations in wetlands are widely considered to be a seed cueing mechanism signaling the drying of mud flats and the presence of conditions suitable for germination (Fenner and Thompson 2005; Leck and Schutz 2005). Germinations typically occur when the temperature rises quickly from $10^{\circ} \mathrm{C}$ or lower. In 
wetlands seeds on bare mud or in shallow water experience such temperature fluctuations, resulting in release from seed dormancy and germination (Fenner 1985; Leck 1989; Vleeshouwers et al. 1995). This mechanism may explain the two observed peaks in germination following cooler nights (Fig. 3a).

Harper et al. (1970) state that when a differential seed size occurs within the same population, i.e., large and small seeds, the differences between the developing individuals become cumulative. Seedlings from the large seeds obtain dominance over and survive at the expense of those from the small seeds, thereby favoring the survival of plants with genes for large seeds. However, in the current study two shorter hydroperiod sites, 2 and 6, produced the most germinations from small seeds (Table 4). Alternatively, environmental factors that influence seed provisioning, e.g., nutrient availability, may be the dominant cause of smaller seed size in these sites. Additional studies of how variation in nutrient levels affects seed mass and germinability are required to test the validity of this hypothesis.

Sawgrass flowers expand from late April to early June in the Everglades. Ripe fruits are primarily released during August (Snyder and Richards 2005). By August, the rain and winds of seasonal storms — coupled with high water levels — provide an optimal environment for hydrochorous sawgrass fruit dispersal (personal observation). Most sawgrass fruits have the ability to float for several days $\left(\mathrm{FD}_{50}=12\right.$ days; Chapter II). Coupled with greater surface water dynamics during August, dispersal to great distances is probable (Chapter III). Water flow rates were historically much greater than they currently are (Lodge 2006). The measured genetic similarity found in sawgrass across the Everglades basin (Ivey and Richards 2001) may have been a consequence of greater historical mixing of traits by hydrochory before anthropogenic manipulations to the Everglades occurred. 


\section{CONCLUSIONS}

Sawgrass fruit mass, fruit length, seed germination, and viable seeds all varied significantly among collection sites and plants in the same population. Germination and potential seed viability varied significantly by collection sites and among plants in the same population. Even though only $17.9 \%$ of seeds germinated throughout the 16 -week study, the observed level of germination is compatible with the germination range of other Everglades species.

Fruits from all germinated seeds plus all potentially viable seeds had higher mean mass than the overall mean mass for all fruits in the study. Only $11.6 \%$ of germinations occurred from fruit less than the comprehensive mean fruit mass. Together, germinated seeds and potentially viable seeds equaled one-fifth of tested seeds.

Cladium jamaicense, and other members of the Cyperaceae, are known to have good buoyancy and small seeds with hard achene fruits. This combination of species traits provides for good dispersibility. Within the species, a wide range of fruit sizes is found, and both large and small seeds germinated in a near parallel pattern over the 16-week study. Small-massed fruits have greater dispersal ability over large distances. Size diversity demonstrates reproductive plasticity within sawgrass, providing for a greater chance of both colonization with small seeds and survival with large seeds.

Further study of the entire process from early seed development to dispersal is required to determine the chronological pattern of seed development, provisioning, and dispersal within each inflorescence, among plants of the same population and among sites. It is possible, for example, that particularly large seeds are provisioned and shed first and smaller ones later. Furthermore, it is not known if changes in the availability of nutrients - such as those released from fire ash—during seed development affects seed provisioning and germination ability. This 
sawgrass germination study seeks to provide enhanced management and reestablishment resources for sawgrass within the on-going Everglades restoration program. 


\section{LITERATURE CITED}

Baker, H. G. 1972. Seed weight in relationship to environmental conditions in California. Ecology 53:997-1010.

Baskin, C. C. and Baskin, J.M. 2001. Seeds: Ecology, Biogeography, and Evolution of Dormancy and Germination. Academic Press, New York, NY. 666 pp.

Brewer, J. S. 1996. Site differences in the clone structure of an emergent sedge, Cladium jamaicense. Aquatic Botany 55:79-91.

Cardel, Y. 2004. Linking herbivory and pollination: costs and selection implications in Centrosoma virginiana. Ph.D. dissertation. Florida International University. Miami, Fla.

Daehler, C. C. and Strong, D.R. 1994. Variable reproduction output among clones of Spartina alterniflora (Poaceae) invading San Francisco Bay, California: the influence of herbivory, pollination, and establishment site. American Journal of Botany 81:307-313

DeViana, M.L. 1999. Seed production and seed bank of Trichocereus pasacana (Cactaceae) in Northern Argentina. Tropical Ecology 10(1):79-84.

Fang, X., P. K. Subudhi, and B.C. Venuto, S.A. Harrison, A.B. Ryan, A.B. 2004. Influence of flowering phenology on seed production in smooth cordgrass (Spartina alterniflora Loisel.). Aquatic Botany 80:139-151

Fenner, M. and K. Thompson. 2005. The Ecology of Seeds. Cambridge University Press. Cambridge, U.K. 250 pp.

Fenner, M. 1985. Seed ecology. Outline Studies in Ecology. Chapman \& Hall. New York, NY. 151pp.

Godfrey, R. A. and J. W. Wooten 1981. Aquatic and Wetland Plants of Southeastern United States: Monocotyledons. University Georgia Press, Athens, GA. 712 pp.

Gotelli, N. J. and A. M. Ellison. 2004. A Primer of Ecological Statistics. Sinauer Assoc., Inc. Sunderland, MA. $510 \mathrm{pp}$.

Gutterman, Y. 1992. Maternal effects on seeds during development. Pgs. 27-59 in: Seeds: the Ecology of Regeneration in Plant Communities, M. Fenner (ed.). CAB International, UK.

Harper, J. L., P. H. Lovell, and K. G. Moore. 1970. The shapes and sizes of seeds. Annual Review of Ecology and Systematics 1:327-356.

Henry, J. A., K. M. Portier, and J. Coyne. 1994. The climate and weather of Florida. Pineapple Press, Inc. Sarasota, FL. 279 pp.

Ivey, C. and J. H. Richards. 2001. Genetic diversity of Everglades sawgrass, Cladium jamaicense (Cyperaceae). International Journal of Plant Science 162:817-825. 
Jayachandran, K. and K. G. Shetty. 2003. Growth response and phosphorus uptake by arbuscular mycorrhizae of wet prairie sawgrass. Aquatic Botany 76:281-290.

Jakobsson, A. and O. Eriksson. 2000. A comparative study of seed number, seed size, seedling size, and recruitment in grassland plants. Oikos 88:494-502.

Johnson, S. 2004. Effects of water level and phosphorous enrichment on seedling emergence from marsh seed banks collected from northern Belize. Aquatic Botany 79:311-323.

Koptur, S., C. L. Smith, and J. H. Lawton. 1996. Effects of artificial defoliation on reproductive allocation in the common vetch, Vicia sativa (Fabaceae: Papilionoideae). American Journal of Botany 83:886-889.

Leck, M. A. 1989. Wetland seed banks. Pgs. 283-305 in: Ecology of Soil Seed Banks. M.A. Leck, V.T. Parker, and R. L. Simpson (eds.). Academic Press, Inc. NY, NY

Leck, M. A. and W. Schutz 2005. Regeneration of Cyperaceae, with particular reference to seed ecology and seed banks. Perspectives in Plant Ecology and Systematics 7:95-133.

Leeds, J. A., S. Newman, and S. M. Smith. 2006. Factors affecting seed germination of Eleocharis cellulosa and Rhynchospora tracyi from the Northern Everglades. Wetlands 26(2):368-375.

Lippitt, L. A. and L. A. Moran. 1993. Three quick seed evaluation methods-A comparison. Restoration and Management Notes 11:172.

Lodge, T. E. 2006. The Everglades Handbook: Understanding the Ecosystem, Second Edition. CRC Press. Boca Raton, FL. 302 pp.

Lorenzen, B., H. Brix, K. L. McKee, I. A. Mendelssohn, and S. L.. Miao. 2000. Seed germination of two Everglades species, Cladium jamaicense and Typha domingensis. Aquatic Botany 66:169-180.

Loveless, C. M. 1959. A study of the vegetation in the Florida Everglades. Ecology 40:1-9.

Miao, S. L., L. Kong, B. Lorenzen, and L. L. Johnson. 1998. Versatile modes of propagation in Cladium jamaicense in the Florida Everglades. Annals of Botany 82:285-290.

Moles, A. T. and M. Westoby. 2003. Latitude, seed predation and seed mass. Journal of Biogeography 30:105-128.

Montalvo, A. M. 1994. Inbreeding depression and maternal effects in Aquilegia caerulea, a partially selfing plant. Ecology 75:2395-409.

Newman, S., J. B. Grace, and J. W. Koebel. 1996. Effects of nutrients and hydroperiod on Typha, Cladium, and Eleocharis: implications for Everglades restoration. Ecological Applications 6:774-783. 
Pinto-Torres, E. and S. Koptur. 2009. Hanging by a coastal strand: breeding system of a federally endangered morning-glory of the south-eastern Florida coast, Jacquemontia reclinata. Annals of Botany. doi:10.1093/aob/mcp241: 11 pgs.

Ponzio, K. J., S. J. Miller, and M. A. Lee. 1995. Germination of sawgrass, Cladium jamaicensis Crantz under varying hydrologic conditions. Aquatic Botany 51:115-120.

Snyder, J. M. and J. H. Richards. 2005. Floral phenology and compatibility of sawgrass, Cladium jamaicense (Cyperaceae). American Journal of Botany 92:736-743.

Schlichting, C. D. 1986. The evolution of phenotypic plasticity in plants. Annual Review of Ecology and Systematics 17:667-693.

Somers, G. F. and D. Grant. 1981. Influence of seed source upon phenology of flowering of Spartina alterniflora Loisel. and the likelihood of cross pollination. American Journal of Botany 68:6-9.

SPSS. 1997. SYSTAT 7.0: Statistics. SPSS, Inc. Chicago, IL. 751 pp.

Steward, K. K. and W. H. Ornes. 1975. The autecology of sawgrass in the Florida Everglades. Ecology 56:162-171.

Strahler, A. and A. Strahler. 1998. Introductory physical geography, Second Edition. J. Wiley and Sons, Inc. 567pp.

Sutton, D. L. 1993. A method for germination of arrowhead, pickerelweed, and spikerush seeds. Tropic Line 6:2-4 (Newsletter of Ft. Lauderdale Research and Education Center, Fla. Coop. Ext. Service)

Venable, D. L. and J. S. Brown. 1988. The selective interactions of dispersal, dormancy, and seed size as adaptations for reducing risk in variable environments. American Naturalist 131:360-384.

Vleeshouwers, L. M., H. J. Bouwmeester, and C. M. Karssen. 1995. Redefining seed dormancy: an attempt to integrate physiology and ecology. Journal of Ecology 83: 10311037. 
Table 1. Collection sites of sawgrass, Cladium jamaicense, infructescences with site

description and approximate hydroperiod. Both latitude-longitude and UTM methods for site location are included for convenience.

\begin{tabular}{|c|c|c|c|c|}
\hline SITE & Lat. \& Long. & UTM Location & SITE DESCRIPTION & HYDROLOGY \\
\hline 1 & $\begin{array}{l}25^{0} 45.63 \mathrm{~N} \\
80^{0} 22.62 \mathrm{~W}\end{array}$ & $\begin{array}{l}\text { 17R 562475.0 } \\
2849308.8\end{array}$ & $\begin{array}{l}\text { Henington Pond, Florida } \\
\text { International University campus, } \\
\text { Tamiami Trail, Miami. Moist } \\
\text { bank of pond with thick organic } \\
\text { substrate. }\end{array}$ & Hydroperiod 8-10 mos. \\
\hline 2 & $\begin{array}{l}25^{0} 46.12 \mathrm{~N} \\
80^{0} 40.42 \mathrm{~W}\end{array}$ & $\begin{array}{l}\text { 17R 532722.4 } \\
2850106.1\end{array}$ & $\begin{array}{l}\text { East base of Levee } 67 \text { and } \\
\text { adjacent marsh, WCA-3A, north } \\
\text { of US- } 41 \text { ca. } 0.5 \text { mi. Substrate } \\
\text { crushed limestone with peat } \\
\text { moist to flooded. }\end{array}$ & Hydroperiod 8-12 mos. \\
\hline 3 & $\begin{array}{l}25^{0} 47.62 \mathrm{~N} \\
80^{0} 34.26 \mathrm{~W}\end{array}$ & $\begin{array}{l}\text { 17R } 0542709 \\
2851948.0\end{array}$ & Central WCA-3A, peat substrate. & $\begin{array}{l}\text { Hydroperiod 11-12 } \\
\text { mos. }\end{array}$ \\
\hline 4 & $\begin{array}{l}25^{0} 45.74 \mathrm{~N} \\
80^{0} 49.37 \mathrm{~W}\end{array}$ & $\begin{array}{l}\text { 17R 517766.0 } \\
2849376.1\end{array}$ & $\begin{array}{l}\text { Drainage canal bank, east side of } \\
\text { Big Cypress Swamp near US } 41 \text {. } \\
\text { Substrate crushed limestone with } \\
\text { peat. }\end{array}$ & $\begin{array}{l}\text { Hydroperiod 10-12 } \\
\text { mos. }\end{array}$ \\
\hline 5 & $\begin{array}{l}25^{0} 45.74 \mathrm{~N} \\
80^{0} 49.54 \mathrm{~W}\end{array}$ & $\begin{array}{l}\text { 17R 517481.8 } \\
2849375.7\end{array}$ & $\begin{array}{l}\text { Drainage canal from Big } \\
\text { Cypress Swamp, further west of } \\
\text { site } 4 \text {. Substrate crushed } \\
\text { limestone with peat. }\end{array}$ & $\begin{array}{l}\text { Hydroperiod 10-12 } \\
\text { mos. }\end{array}$ \\
\hline 6 & $\begin{array}{l}25^{0} 23.80 \mathrm{~N} \\
80^{0} 28.31 \mathrm{~W}\end{array}$ & $\begin{array}{l}\text { 17R 553125.3 } \\
2808976.3\end{array}$ & $\begin{array}{l}\text { About } 3 \text { mi. south of jct. US-1 \& } \\
\text { Card Sound Rd., Everglades } \\
\text { marl marsh, west side of road. }\end{array}$ & Hydroperiod 6-8 mos. \\
\hline 7 & $\begin{array}{l}25^{0} 24.02 \mathrm{~N} \\
80^{0} 28.03 \mathrm{~W}\end{array}$ & $\begin{array}{l}\text { 17R 553593.0 } \\
2809384.1\end{array}$ & $\begin{array}{l}\text { Singletary parcel across US-1 } \\
\text { from above, isolated Everglades } \\
\text { marsh east side of road. }\end{array}$ & Hydroperiod 8-10 mos. \\
\hline 8 & $\begin{array}{l}25^{0} 46.32 \mathrm{~N} \\
80^{0} 40.42 \mathrm{~W}\end{array}$ & $\begin{array}{l}\text { 17R 532721.5 } \\
2850475.2\end{array}$ & $\begin{array}{l}\text { West canal bank at base of } \\
\text { Levee } 67 \text { north of US- } 41 \text { ca. } 1 \mathrm{mi} \text {. } \\
\text { Substrate crushed limestone with } \\
\text { peat. }\end{array}$ & Hydroperiod 8-10 mos. \\
\hline 9 & $\begin{array}{l}25^{0} 48.60 \mathrm{~N} \\
80^{0} .40 .42 \mathrm{~W}\end{array}$ & $\begin{array}{l}\text { 17R 532711.1 } \\
2854683.4\end{array}$ & $\begin{array}{l}\text { West canal bank at base of } \\
\text { Levee } 67 \text { north of US- } 41 \text { north } \\
\text { of site } 8 . \text { Substrate crushed } \\
\text { limestone with peat. }\end{array}$ & Hydroperiod 8-10 mos. \\
\hline 10 & $\begin{array}{l}25^{0} 47.56 \mathrm{~N} \\
80^{0} 40.42 \mathrm{~W}\end{array}$ & $\begin{array}{l}\text { 17R 532715.9 } \\
2852763.9\end{array}$ & $\begin{array}{l}\text { West canal bank at base of } \\
\text { Levee } 67 \text { north of US- } 41 \text { north } \\
\text { of site } 9 \text { among Salix } \\
\text { caroliniana. Substrate peat with } \\
\text { some limestone fines. }\end{array}$ & $\begin{array}{l}\text { Hydroperiod 10-12 } \\
\text { mos. }\end{array}$ \\
\hline
\end{tabular}


Table 2. Mass and length for fruits, seeds germinated, and seeds viable for sawgrass. (a) by site. Site numbers refer to numbers in Table 1. \#Germin. is number of seeds germinated out of 375 planted/site. \# RViable is number of remaining ungerminated seeds with good endosperm of ungerminated seeds/site. Fruit mass and length expressed as means \pm S.E. (b) The same categories as Table 2a but with data partitioned for the location of collected fruits - the upper, middle, and lower third portions of the 50 sawgrass infructescences evaluated.

2 a. BY SITE NUMBER

\begin{tabular}{|c|c|c|c|c|c|}
\hline Site & $\begin{array}{l}\text { \#Germin. } \\
\text { and \% of } \\
\text { Site }\end{array}$ & $\begin{array}{c}\text { \#RViable } \\
\text { and \% of } \\
\text { Site }\end{array}$ & $\begin{array}{l}\text { Ratio of } \\
\text { Germin./ } \\
\text { RViable }\end{array}$ & $\begin{array}{l}\text { Fruit } \\
\text { Mass } \\
\text { (mg) }\end{array}$ & $\begin{array}{c}\text { Fruit } \\
\text { Length } \\
\text { (mm) }\end{array}$ \\
\hline 1 & $\begin{array}{ll}63 & (59.4 \%)\end{array}$ & $43 \quad(40.6 \%)$ & 1.4 & $3.2 \pm 1.0$ & $2.9 \pm 0.3$ \\
\hline 2 & $104(95.4 \%)$ & $(4.6 \%)$ & 20.7 & $2.6 \pm 1.0$ & $2.9 \pm 0.3$ \\
\hline 3 & $150 \quad(90.4 \%)$ & $16 \quad(9.6 \%)$ & 9.4 & $3.3 \pm 0.7$ & $3.0 \pm 0.2$ \\
\hline 4 & $\begin{array}{ll}5 & (83.3 \%)\end{array}$ & $(16.7 \%)$ & 4.9 & $2.1 \pm 0.6$ & $2.9 \pm 0.3$ \\
\hline 5 & $7 \quad(58.3 \%)$ & $(41.7 \%)$ & 1.4 & $1.9 \pm 0.5$ & $2.8 \pm 0.3$ \\
\hline 6 & $143 \quad(86.7 \%)$ & $22 \quad(13.3 \%)$ & 6.5 & $2.6 \pm 0.6$ & $2.9 \pm 0.2$ \\
\hline 7 & $40 \quad(80.0 \%)$ & $\begin{array}{ll}10 \quad(20.0 \%) \\
\end{array}$ & 4.0 & $2.6 \pm 0.6$ & $3.0 \pm 0.2$ \\
\hline 8 & $57 \quad(61.3 \%)$ & $36 \quad(38.7 \%)$ & 1.6 & $3.2 \pm 0.9$ & $3.1 \pm 0.4$ \\
\hline 9 & $\begin{array}{ll}50 & (92.6 \%)\end{array}$ & $4 \quad(7.4 \%)$ & 12.5 & $3.2 \pm 1.1$ & $3.1 \pm 0.4$ \\
\hline 10 & $45 \quad(91.8 \%)$ & $(8.3 \%)$ & 11.3 & $2.5 \pm 0.8$ & $2.9 \pm 0.3$ \\
\hline Seed Totals $($ of $n=3700)$ & $664(17.4 \%)$ & $146 \quad(4.0 \%)$ & 4.5 & -- & -- \\
\hline Means \pm S.E. & 66.4 & 14.6 & -- & $2.7 \pm 0.9$ & $3.0 \pm 0.3$ \\
\hline Medians \pm S.E. & 53.5 & 7.5 & - & 2.6 & 3.0 \\
\hline
\end{tabular}

2 b. BY PLANT LOCATION

\begin{tabular}{|l|l|l|l|l|l|}
\hline Upper Infructescence Mean & 238 & 53 & -- & $2.8 \pm 0.9$ & $3.0 \pm 0.3$ \\
\hline Middle Infructescence Mean & 224 & 44 & -- & $2.8 \pm 0.7$ & $3.0 \pm 0.3$ \\
\hline Lower Infructescence Mean & 202 & 49 & -- & $2.7 \pm 1.0$ & $3.0 \pm 0.3$ \\
\hline
\end{tabular}


Table 3. Nested ANOVA testing the effect of site, individual plant, infructescence location, and relevant covariates for significant effect on fruit mass, fruit length, number of germinations, and number of viable seeds. The df columns each contain the Hypothesis df value followed by the Error df value. The underlined $\boldsymbol{p}$ values are significant at the $95 \%$ level. Since seed germination and viable seed values were binary, they were arcsine $(\mathrm{SqRt}(($ variable $+0.375 / 25.75)))$ transformed prior to analysis.

\begin{tabular}{|c|c|c|c|c|c|c|c|c|c|c|c|c|}
\hline \multirow[t]{2}{*}{$\begin{array}{c}\text { Source of } \\
\text { Variation }\end{array}$} & \multicolumn{3}{|c|}{ Fruit Mass } & \multicolumn{3}{|c|}{ Fruit Length } & \multicolumn{3}{|c|}{ Mean Germination } & \multicolumn{3}{|c|}{$\begin{array}{l}\text { Mean Viable } \\
\text { Seed }\end{array}$} \\
\hline & df & $\mathbf{F}$ & $p$ & df & $\mathbf{F}$ & $p$ & df & $\mathbf{F}$ & $p$ & df & $\mathbf{F}$ & $p$ \\
\hline Site & $\begin{array}{c}9, \\
32.5\end{array}$ & 5.86 & $<\underline{0.001}$ & $\begin{array}{c}9, \\
31.6\end{array}$ & 3.38 & $\underline{0.005}$ & \begin{tabular}{c|}
9, \\
35.1
\end{tabular} & 4.16 & $\underline{0.001}$ & $\begin{array}{c}9, \\
34.4\end{array}$ & 2.81 & $\underline{0.014}$ \\
\hline $\begin{array}{c}\text { Individual } \\
\text { Plant }\end{array}$ & $\begin{array}{c}4, \\
32.9\end{array}$ & 1.59 & 0.201 & $\begin{array}{c}4, \\
32.0\end{array}$ & 1.77 & 0.159 & $\begin{array}{c}4, \\
35.2\end{array}$ & 1.43 & 1.43 & \begin{tabular}{|c|}
4, \\
30.9
\end{tabular} & 2.31 & 0.080 \\
\hline $\begin{array}{l}\text { Infructescence } \\
\text { Location }\end{array}$ & $\begin{array}{c}2, \\
2.3\end{array}$ & 1.23 & 0.433 & $\begin{array}{l}2, \\
4\end{array}$ & 0.882 & 0.482 & \begin{tabular}{|c|}
2 \\
7.3
\end{tabular} & 0.653 & 0.548 & \begin{tabular}{|l}
2 \\
6.0
\end{tabular} & 0.388 & 0.695 \\
\hline $\begin{array}{c}\text { Site } \\
\mathbf{x} \\
\text { Individual Plant }\end{array}$ & $\begin{array}{l}36 \\
72\end{array}$ & 8.09 & $<\underline{0.001}$ & $\begin{array}{l}36 \\
72\end{array}$ & 5.90 & $<\underline{0.001}$ & $\begin{array}{l}36 \\
72\end{array}$ & 7.98 & $<\underline{0.001}$ & $\begin{array}{l}36, \\
72\end{array}$ & 5.62 & $<\underline{0.001}$ \\
\hline $\begin{array}{c}\text { Site } \\
x \\
\text { Infructescence } \\
\text { Location } \\
\end{array}$ & $\begin{array}{l}18, \\
72\end{array}$ & 0.687 & 0.813 & $\begin{array}{l}18 \\
72\end{array}$ & 0.762 & 0.736 & $\begin{array}{l}18, \\
72\end{array}$ & 1.07 & 0.399 & \begin{tabular}{|l}
18 \\
72
\end{tabular} & 1.14 & 0.336 \\
\hline $\begin{array}{c}\text { Individual Plant } \\
x \\
\text { Infructescence } \\
\text { Location }\end{array}$ & $\begin{array}{l}8 \\
72\end{array}$ & 0.869 & 0.547 & $\begin{array}{l}8, \\
72\end{array}$ & 1.17 & 0.330 & $\begin{array}{l}8, \\
72\end{array}$ & 1.82 & 0.088 & \begin{tabular}{|l}
8 \\
72
\end{tabular} & 0.952 & 0.486 \\
\hline
\end{tabular}


Table 4. Distribution of germinations by site and five fruit mass categories. Data are numbers of seeds that germinated in each fruit mass category. The mass for fruits that germinated shows that fruit mass and range for mass varies by site. Sites with an "*” show deviation from the overall total mass distribution pattern. The means for fruit mass by site are shown in Table 2 .

\begin{tabular}{|c|c|c|c|c|c|c|c|}
\hline Site & $\begin{array}{c}1) \\
<2.7 \\
\mathrm{mg}\end{array}$ & $\begin{array}{c}(2) \\
2.7-2.9 \\
\mathrm{mg}\end{array}$ & $\begin{array}{c}(3) \\
3.0-3.9 \\
\mathrm{mg}\end{array}$ & $\begin{array}{c}(4) \\
4.0-4.9 \\
\mathrm{mg}\end{array}$ & $\begin{array}{c}(5) \\
5.0-5.9 \\
\mathrm{mg}\end{array}$ & Site Sums & $\begin{array}{c}\text { Range } \\
(\mathrm{mg})\end{array}$ \\
\hline 1* & 1 & 1 & 24 & 31 & 6 & 63 & $2.6-5.8$ \\
\hline 2* & 11 & 13 & 63 & 17 & 0 & 104 & $1.5-4.9$ \\
\hline 3 & 4 & 12 & 82 & 52 & 0 & 150 & $1.9-4.6$ \\
\hline 4 & 2 & 0 & 2 & 1 & 0 & 5 & $2.5-4.1$ \\
\hline 5 & 5 & 1 & 1 & 0 & 0 & 7 & $1.6-3.4$ \\
\hline 6* & 41 & 32 & 70 & 0 & $\overline{0}$ & 143 & $1.3-3.9$ \\
\hline 7 & 7 & 6 & 26 & 1 & 0 & 40 & $2.3-4.3$ \\
\hline 8 & 2 & 2 & 35 & 18 & 0 & 57 & $2.2-4.5$ \\
\hline 9 & 2 & 1 & 15 & 29 & 3 & 50 & $1.1-5.5$ \\
\hline 10 & 2 & 1 & 26 & 16 & 0 & 45 & $1.8-4.7$ \\
\hline $\begin{array}{c}\text { Fruit Mass } \\
\text { Totals }\end{array}$ & 77 & 69 & 344 & 165 & 9 & 664 & --- \\
\hline
\end{tabular}




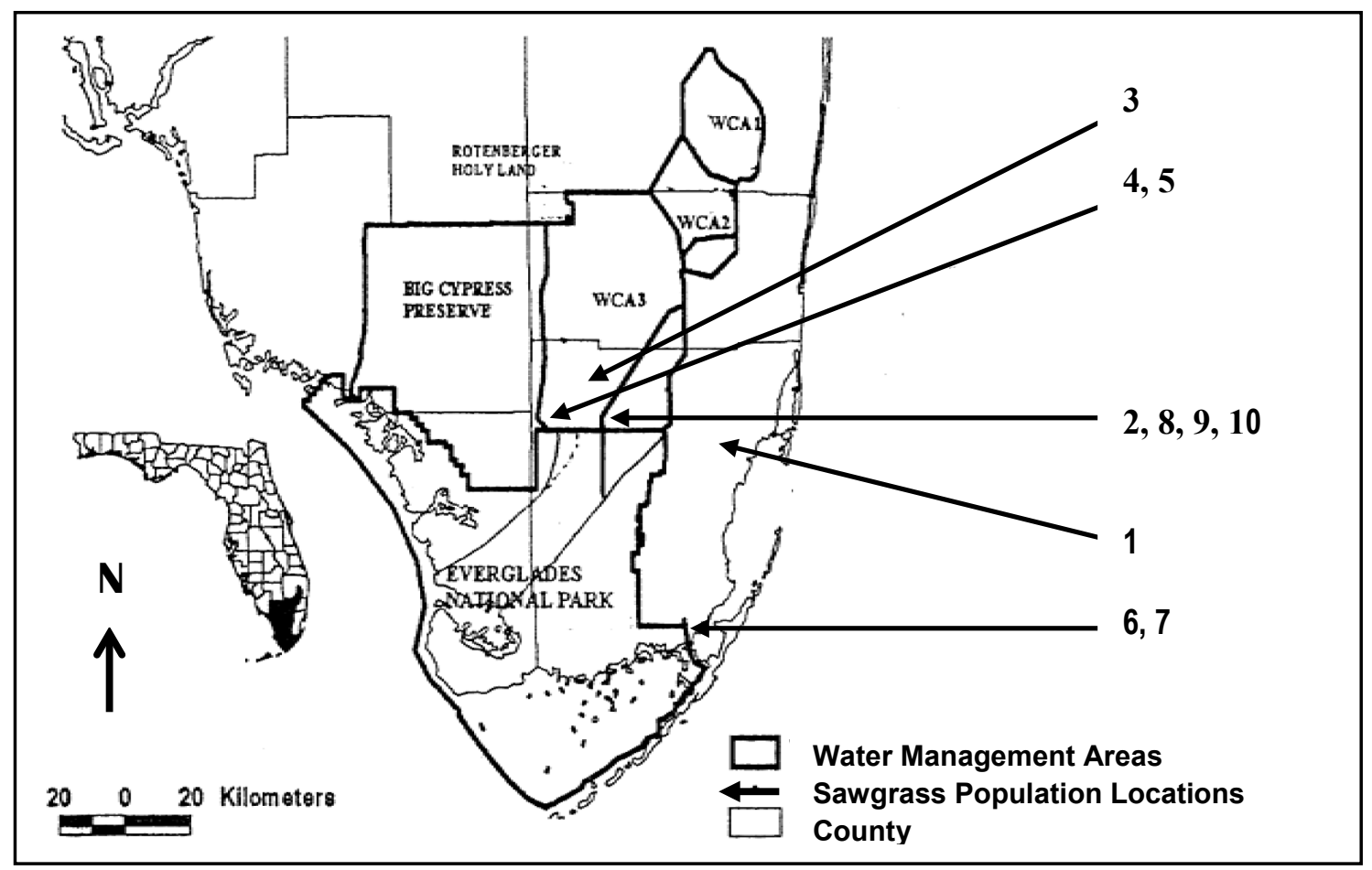

Figure 1. South Florida map with sawgrass infructescence collection sites. Numbers above refer to site numbers in Table 1 


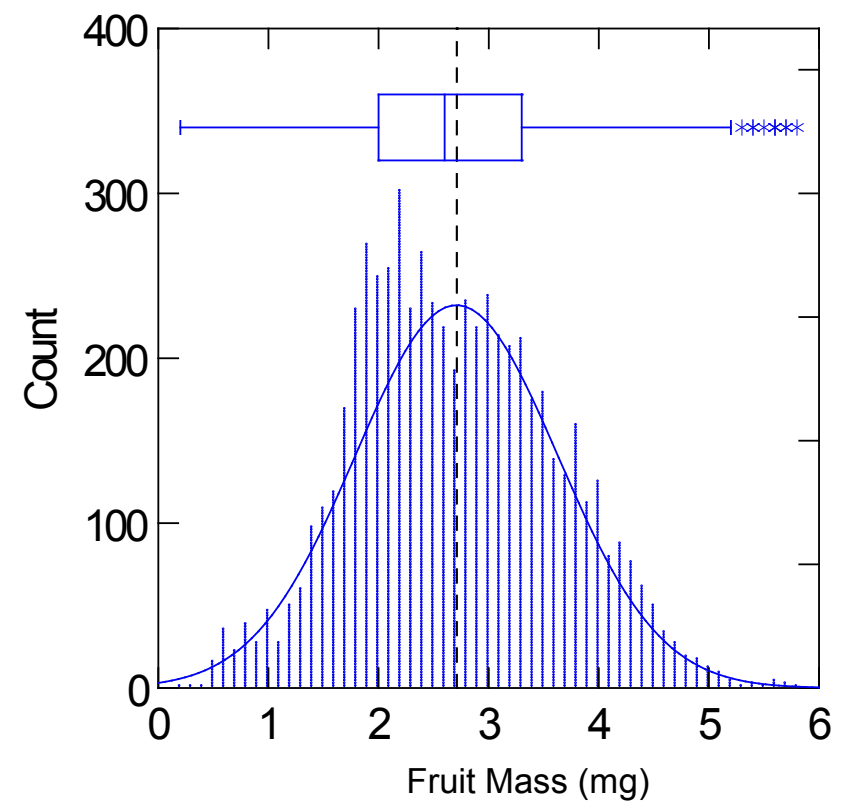

Figure 2. The t-distribution of sawgrass fruit mass. The graph shows that the mean fruit mass is close to a normal distribution. Several outliers are indicated at the high end of the plot. The broken vertical line indicates the mean $(2.7 \pm 0.9 \mathrm{mg}, \mathrm{n}=3,750)$. 

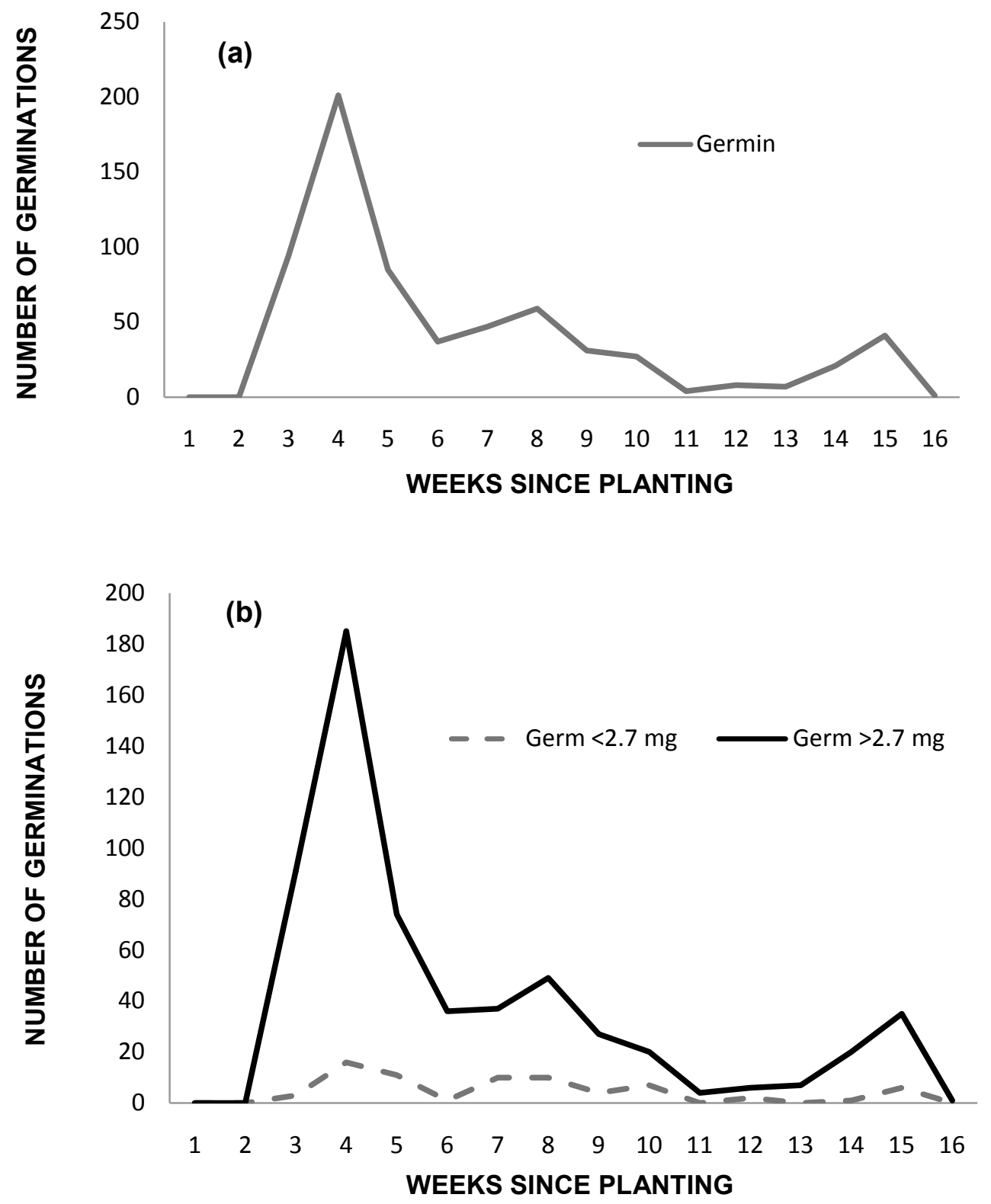

Figure 3. The pattern of all seed germinations over the 16-week (27 November 2005 to 19 March 2006) shade house study (a) and germinations by week according to fruit mass (b). After a large initial peak, two smaller peaks appeared at 8 and 15 weeks (2-3 weeks after several hours of low temperature, $<7^{\circ} \mathrm{C}$ ). The solid line shows germinations from fruits greater than the $2.7 \mathrm{mg}$ fruit mean, while the broken line shows germinations from seeds $<2.7 \mathrm{mg}$. 


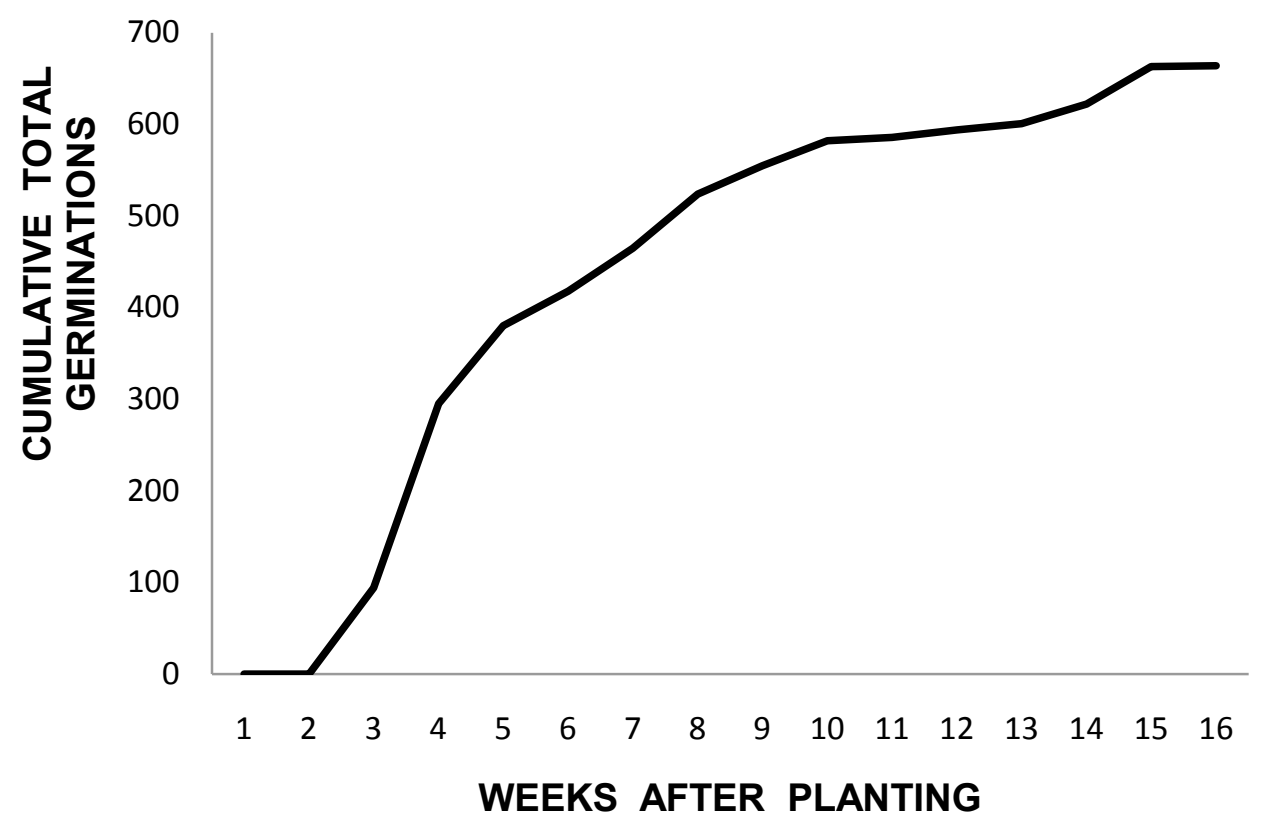

Figure 4. Cumulative sawgrass germinations during the 16-week study. 


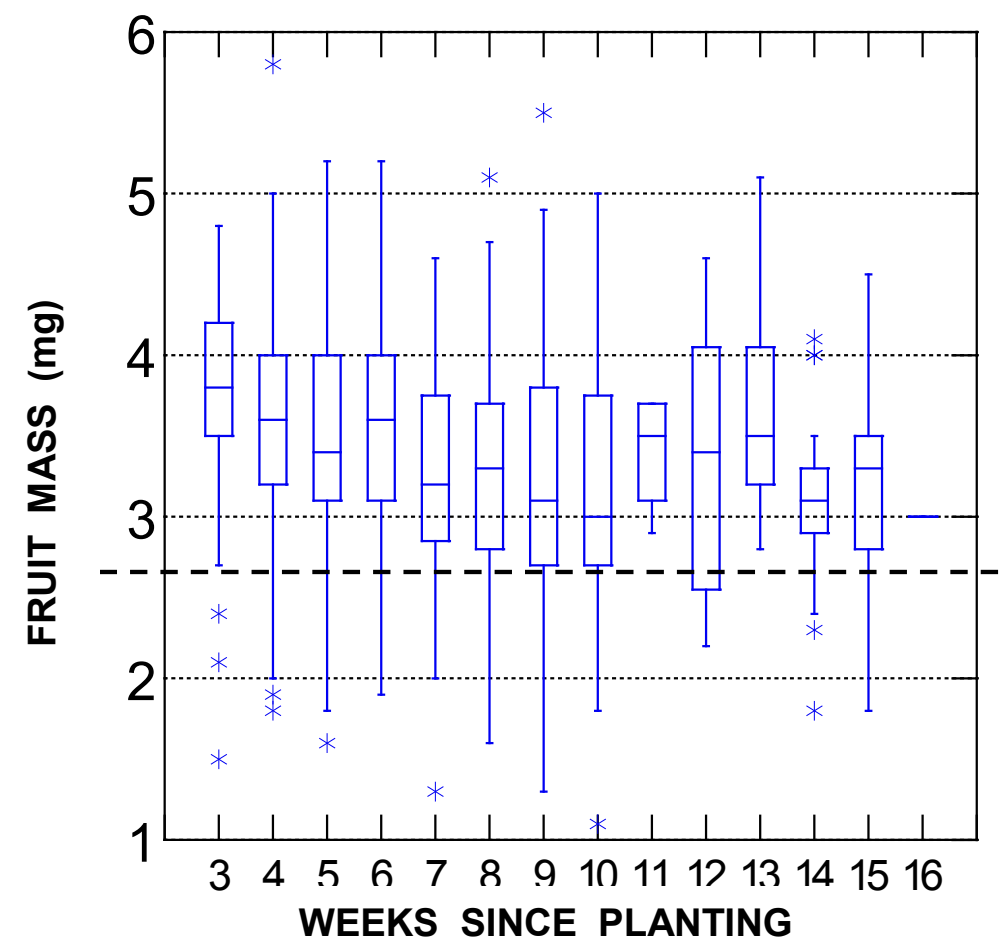

Figure 5. Pattern of fruit mass germinations by each week since planting. The mean mass for all 3,700 fruits tested was $2.7 \mathrm{mg}$ (broken line). 

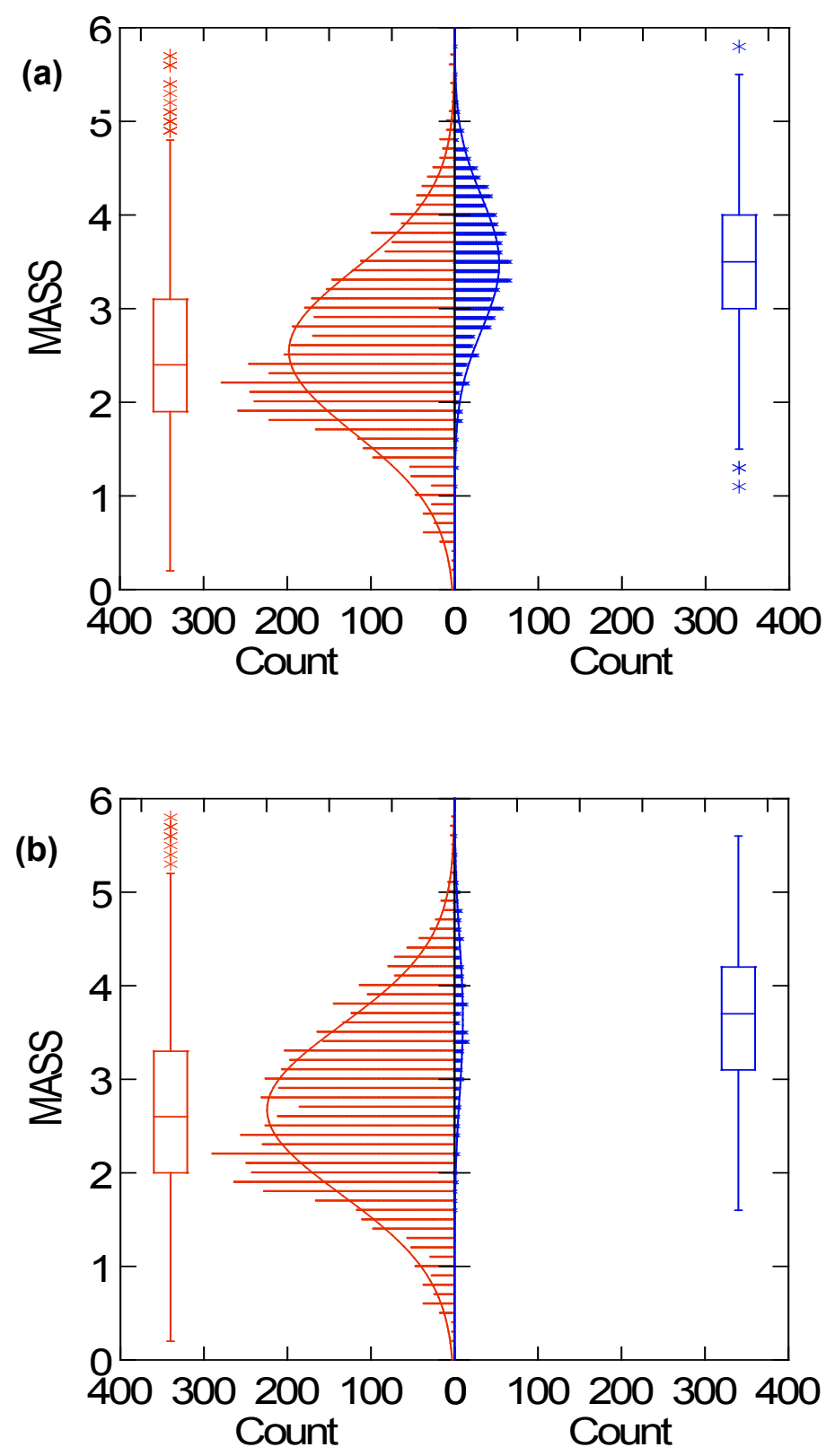

Figure 6. The paired t-tests for Cladium jamaicense fruits. (a) Mass for fruits with germinated seeds (right) with all 3,700 tested fruits (left). The mean for fruits with germinated seeds (right) was $3.5 \pm 0.7$ S.E. $m g$ while the overall fruit mean (left) was $2.7 \pm 0.9$ S.E. mg. (b) Mass for fruits with remaining potentially viable seed (right) with all tested fruits (left). The mean for potentially viable seeds was $3.7 \pm 0.8$ S.E. $\mathrm{mg}$. 


\section{CHAPTER V}

\section{CONCLUSION}

The understanding of plant reproduction analysis in the Everglades has been expanded with this study to include mechanisms of seed dispersal, seedbank composition, and sawgrass germination patterns. Methods of seed dispersal were determined for 51 marsh species.

Hydrochory is the dominant method of dispersal. Each of the four dominant dispersal methods, hydrochory, anemochory, endozoochory, and epizoochory, has its own specific set of functional traits (syndrome) held by a group of species. Each of these syndromes encompasses a broad web of characteristics appropriately cued to environmental variations that often provide additional dispersal options. However, in some species, dispersal is random and dispersalenhancing functional traits are lacking. For example, in species with non-buoyant diaspores, the diaspores can opportunistically fall upon floating algal mats.

In community assembly theory, trends and patterns form the characteristic rules in a community. Among the functional traits that support dispersal syndromes are seasonal timing, diaspore size and buoyancy, and water flow rate. These traits are fundamental to hydrochory. Most species disperse during seasonal flooding — typically from June to January. Diaspore size is a correlated trait. Diaspores dispersing early in the wet season typically have a smaller mass and greater buoyancy than those dispersing later. Diaspores with a smaller mass can disperse faster and farther than diaspores with a larger mass. Adequate water flow is necessary for hydrochory. Significant seed movement rate was supported by tests conducted showing adequate surface water flow in sloughs. Opportunistic dispersal may occur through the newly named dispersal method termed phycochory, involving the attachment of diaspores to algal litter that eventually floats into sawgrass patch edges.

Dispersed seeds eventually germinate, become part of the soil seedbank, or die. Trends for germination and seed viability were determined by the results of rate of germination and 
sectioning of sawgrass seed tests. Diaspores with a smaller mass have lower germination and survival abilities than those with a larger mass. As a trade-off, however, smaller diaspores disperse farther than larger diaspores.

It is proposed that storm-generated pulses of water provide for enhanced distant dispersal, and that these same storm pulses have contributed to the maintenance of the historical ridge-and-slough marsh topography, shaped the sawgrass patch edges, and deposited periphyton litter on the patches. Some surviving seeds also become part of the patch seedbank and others germinate among the newly deposited litter as water levels fall. Seeds of dominant Everglades species were found to germinate better in such moist—rather than inundated—soils, and occasionally seeds germinate on the surface of floating algal mats.

The trends among sawgrass patch seedbanks center on seed positioning and species composition patterns. The dominant species found in sawgrass patch seedbanks were Eleocharis cellulosa, Sagittaria lancifolia, Rhynchospora tracyi, and Cladium jamaicense. These species have been considered dominants in the historical Everglades. As a consequence of surface flow and prevailing lower water current dynamics, seeds were found to collect at the north side of patches and with greatest density along the outermost one meter of sawgrass patches. The number of germinations varied widely among sites - a feature in common with other wetlands. Site was found to influence fruit size, germinability, and viability of seeds. As seed mass increases above the mean mass, the number of germinations and viable seeds increases. Seed dispersal, dormancy, and mass are three main life history traits which have been hypothesized to vary among species, so that if one decreases the other two increase; namely, with lower diaspore mass dispersal and dormancy should increase. However, this pattern was not found to be present in the Everglades when buoyancy duration was used as a measure of dispersal ability. 
As a consequence of anthropogenic manipulation, the Everglades lacks storm pulsing - a necessity for hydrochory, substrate conditions for seed germination, and storm reshaping of sawgrass patches. Compartmentalization of the Everglades also limits the extent of hydrochory. This study, conducted in NW Shark River Slough of Everglades National Park, contains more historically important plant species than do the seedbank studies conducted in WCA-2A just south of agricultural fields of the northern Everglades. This study can serve as a reference or baseline study for southern and less agriculturally-impacted seedbanks, seed dispersal dynamics, and sawgrass germination ability within the planned restoration efforts.

Future studies are suggested for seedbank analyses of solution holes and nested microecosystems in the Everglades, beyond sawgrass patches. Post severe-storm wrack might also be studied for seeds. The effects of heat and charate chemicals from fires should be evaluated for their effects on seed germination. 
Appendix A. Species reproductive phenology data by month of species flowering (F) and dispersing (D) for flowering plants in Shark River Slough, ENP. *= From nursery grown material and college native plant preserve. $\#=$ From literature; species unable to be monitored for dispersal.

\begin{tabular}{|c|c|c|c|c|c|c|c|c|c|c|c|c|}
\hline SPECIES & $\mathbf{J}$ & $\mathbf{F}$ & M & $\mathbf{A}$ & $\mathbf{M}$ & $\mathbf{J}$ & $\mathbf{J}$ & $\mathbf{A}$ & $\mathbf{S}$ & $\mathbf{O}$ & $\mathbf{N}$ & D \\
\hline \multicolumn{13}{|l|}{1 - GRAMINOIDS (n=14) } \\
\hline Bulbostylis ciliatifolia & & & & & & & & & $\mathrm{F}$ & $\mathrm{D}$ & & \\
\hline Cladium jamaicense & & & & $\mathrm{F}$ & $\mathrm{F}$ & $\mathrm{F}$ & $\mathrm{D}$ & $\mathrm{D}$ & & & & \\
\hline Cyperus odoratus & $\mathrm{F}$ & & & $\mathrm{F}$ & $\mathrm{F}$ & $\mathrm{F}$ & $\begin{array}{l}F \\
D\end{array}$ & $\begin{array}{l}F \\
D\end{array}$ & $\mathrm{D}$ & $\begin{array}{l}F \\
D\end{array}$ & $\begin{array}{l}\text { F } \\
D\end{array}$ & $\begin{array}{l}\text { F } \\
D\end{array}$ \\
\hline Dichanthelium dichotomum & & & & & $\mathrm{F}$ & $\begin{array}{l}F \\
D\end{array}$ & $\begin{array}{l}F \\
\mathrm{D}\end{array}$ & $\begin{array}{l}\mathrm{F} \\
\mathrm{D}\end{array}$ & $\begin{array}{l}\mathrm{F} \\
\mathrm{D}\end{array}$ & $\begin{array}{l}\mathrm{F} \\
\mathrm{D}\end{array}$ & $\begin{array}{l}\mathrm{F} \\
\mathrm{D}\end{array}$ & $\mathrm{D}$ \\
\hline Eleocharis cellulosa & & $\mathrm{D}$ & $\begin{array}{l}\mathrm{F} \\
\mathrm{D}\end{array}$ & $\mathrm{F}$ & $\mathrm{F}$ & $\begin{array}{l}F \\
D\end{array}$ & $\begin{array}{l}F \\
D\end{array}$ & $\begin{array}{l}\mathrm{F} \\
\mathrm{D}\end{array}$ & $\begin{array}{l}\mathrm{F} \\
\mathrm{D}\end{array}$ & $\begin{array}{l}\mathrm{F} \\
\mathrm{D}\end{array}$ & $\begin{array}{l}\mathrm{F} \\
\mathrm{D}\end{array}$ & $\begin{array}{l}F \\
D\end{array}$ \\
\hline Eleocharis interstincta & $\begin{array}{l}\mathrm{F} \\
\mathrm{D}\end{array}$ & & $\begin{array}{l}F \\
D\end{array}$ & $\begin{array}{l}F \\
D\end{array}$ & $\mathrm{D}$ & & $\mathrm{F}$ & $\mathrm{F}$ & $\begin{array}{l}\mathrm{F} \\
\mathrm{D}\end{array}$ & $\begin{array}{l}F \\
D\end{array}$ & $\begin{array}{l}F \\
D\end{array}$ & $\begin{array}{l}\text { F } \\
D\end{array}$ \\
\hline Fuirena breviseta & $\mathrm{D}$ & & $\begin{array}{l}F \\
D\end{array}$ & $\mathrm{D}$ & $\mathrm{F}$ & $\begin{array}{l}F \\
D\end{array}$ & $\begin{array}{l}F \\
D\end{array}$ & $\begin{array}{l}F \\
D\end{array}$ & $\begin{array}{l}F \\
D\end{array}$ & $\begin{array}{l}\mathrm{F} \\
\mathrm{D}\end{array}$ & $\begin{array}{l}F \\
D\end{array}$ & $\begin{array}{l}\text { F } \\
D\end{array}$ \\
\hline Juncus megacephalus & $\mathrm{D}$ & & & $\mathrm{F}$ & $\begin{array}{l}\mathrm{F} \\
\mathrm{D}\end{array}$ & $\begin{array}{l}\text { F } \\
D\end{array}$ & $\begin{array}{l}F \\
D\end{array}$ & $\begin{array}{l}F \\
D\end{array}$ & $\begin{array}{l}\mathrm{F} \\
\mathrm{D}\end{array}$ & $\begin{array}{l}\mathrm{F} \\
\mathrm{D}\end{array}$ & $\begin{array}{l}F \\
D\end{array}$ & $\mathrm{D}$ \\
\hline Panicum hemitomon & & & & & $\mathrm{F}$ & $\mathrm{F}$ & $\begin{array}{l}\mathrm{F} \\
\mathrm{D}\end{array}$ & $\begin{array}{l}\mathrm{F} \\
\mathrm{D}\end{array}$ & $\begin{array}{l}\mathrm{F} \\
\mathrm{D}\end{array}$ & $\begin{array}{l}\mathrm{F} \\
\mathrm{D}\end{array}$ & $\begin{array}{l}\mathrm{F} \\
\mathrm{D}\end{array}$ & \\
\hline Rhynchospora colorata & $\begin{array}{l}\mathrm{F} \\
\mathrm{D}\end{array}$ & $\begin{array}{l}F \\
D\end{array}$ & $\begin{array}{l}\mathrm{F} \\
\mathrm{D}\end{array}$ & $\begin{array}{l}\mathrm{F} \\
\mathrm{D}\end{array}$ & $\begin{array}{l}\mathrm{F} \\
\mathrm{D}\end{array}$ & $\begin{array}{l}F \\
D\end{array}$ & $\begin{array}{l}\mathrm{F} \\
\mathrm{D}\end{array}$ & $\begin{array}{l}\mathrm{F} \\
\mathrm{D}\end{array}$ & $\begin{array}{l}\mathrm{F} \\
\mathrm{D}\end{array}$ & $\begin{array}{l}\mathrm{F} \\
\mathrm{D}\end{array}$ & $\begin{array}{l}\mathrm{F} \\
\mathrm{D}\end{array}$ & $\begin{array}{l}\mathrm{F} \\
\mathrm{D}\end{array}$ \\
\hline Rhynchospora inundata & & & & $\mathrm{F}$ & $\mathrm{F}$ & $\begin{array}{l}F \\
D\end{array}$ & $\begin{array}{l}\mathrm{F} \\
\mathrm{D}\end{array}$ & $\begin{array}{l}\mathrm{F} \\
\mathrm{D}\end{array}$ & $\begin{array}{l}\mathrm{F} \\
\mathrm{D}\end{array}$ & $\begin{array}{l}\mathrm{F} \\
\mathrm{D}\end{array}$ & $\mathrm{D}$ & \\
\hline Rhynchospora microcarpa & $\begin{array}{l}\mathrm{F} \\
\mathrm{D}\end{array}$ & $\begin{array}{l}F \\
D\end{array}$ & $\begin{array}{l}\mathrm{F} \\
\mathrm{D}\end{array}$ & $\begin{array}{l}\mathrm{F} \\
\mathrm{D}\end{array}$ & $\begin{array}{l}\mathrm{F} \\
\mathrm{D}\end{array}$ & $\begin{array}{l}\text { F } \\
D\end{array}$ & $\begin{array}{l}\mathrm{F} \\
\mathrm{D}\end{array}$ & $\begin{array}{l}\mathrm{F} \\
\mathrm{D}\end{array}$ & $\begin{array}{l}\mathrm{F} \\
\mathrm{D}\end{array}$ & $\begin{array}{l}\mathrm{F} \\
\mathrm{D}\end{array}$ & $\begin{array}{l}\mathrm{F} \\
\mathrm{D}\end{array}$ & $\begin{array}{l}\mathrm{F} \\
\mathrm{D}\end{array}$ \\
\hline Rhynchospora tracyi & & $\mathrm{F}$ & $\mathrm{F}$ & $\begin{array}{l}\mathrm{F} \\
\mathrm{D}\end{array}$ & $\begin{array}{l}\mathrm{F} \\
\mathrm{D}\end{array}$ & $\begin{array}{l}\text { F } \\
D\end{array}$ & $\begin{array}{l}\mathrm{F} \\
\mathrm{D}\end{array}$ & $\begin{array}{l}\mathrm{F} \\
\mathrm{D}\end{array}$ & $\begin{array}{l}\mathrm{F} \\
\mathrm{D}\end{array}$ & $\mathrm{D}$ & $\mathrm{F}$ & $\begin{array}{l}\mathrm{F} \\
\mathrm{D}\end{array}$ \\
\hline Scleria verticillata & & & & & $\mathrm{F}$ & $\begin{array}{l}\text { F } \\
D\end{array}$ & $\begin{array}{l}\text { F } \\
\text { D }\end{array}$ & $\begin{array}{l}\text { F } \\
D\end{array}$ & $\begin{array}{l}\mathrm{F} \\
\mathrm{D}\end{array}$ & $\begin{array}{l}\mathrm{F} \\
\mathrm{D}\end{array}$ & $\mathrm{D}$ & \\
\hline $2-$ FORBS $(n=27)$ & & & & & & & & & & & & \\
\hline $\begin{array}{l}\text { Aeschynomene pratensis var. } \\
\text { pratensis }\end{array}$ & $\begin{array}{l}\mathrm{F} \\
\mathrm{D}\end{array}$ & $\begin{array}{l}\mathrm{F} \\
\mathrm{D}\end{array}$ & $\begin{array}{l}\mathrm{F} \\
\mathrm{D}\end{array}$ & $\begin{array}{l}\mathrm{F} \\
\mathrm{D}\end{array}$ & $\begin{array}{l}\mathrm{F} \\
\mathrm{D}\end{array}$ & $\begin{array}{l}\mathrm{F} \\
\mathrm{D}\end{array}$ & $\begin{array}{l}\mathrm{F} \\
\mathrm{D}\end{array}$ & $\begin{array}{l}\mathrm{F} \\
\mathrm{D}\end{array}$ & $\mathrm{D}$ & $\mathrm{F}$ & $\mathrm{F}$ & $\begin{array}{l}\mathrm{F} \\
\mathrm{D}\end{array}$ \\
\hline Agalinis linifolia & $\begin{array}{l}\mathrm{F} \\
\mathrm{D}\end{array}$ & $\mathrm{F}$ & $\begin{array}{l}\mathrm{F} \\
\mathrm{D}\end{array}$ & $\begin{array}{l}\mathrm{F} \\
\mathrm{D}\end{array}$ & $\begin{array}{l}\mathrm{F} \\
\mathrm{D}\end{array}$ & $\begin{array}{l}\mathrm{F} \\
\mathrm{D}\end{array}$ & $\begin{array}{l}\mathrm{F} \\
\mathrm{D}\end{array}$ & $\begin{array}{l}\mathrm{F} \\
\mathrm{D}\end{array}$ & $\begin{array}{l}\mathrm{F} \\
\mathrm{D}\end{array}$ & $\begin{array}{l}\mathrm{F} \\
\mathrm{D}\end{array}$ & $\begin{array}{l}\mathrm{F} \\
\mathrm{D}\end{array}$ & $\mathrm{F}$ \\
\hline Asclepias lanceolata & & & & $\mathrm{F}$ & $\begin{array}{l}\mathrm{F} \\
\mathrm{D}\end{array}$ & $\begin{array}{l}F \\
D\end{array}$ & $\mathrm{D}$ & $\mathrm{D}$ & & & & \\
\hline Boehmeria cylindrica & & & & & & $\begin{array}{l}\mathrm{F} \\
\mathrm{D}\end{array}$ & $\begin{array}{l}\mathrm{F} \\
\mathrm{D}\end{array}$ & $\mathrm{D}$ & & & & \\
\hline Canna flaccida & & & & & & & $\mathrm{F}^{*}$ & $\mathrm{~F}^{*}$ & $\begin{array}{l}\mathrm{F}^{*} \\
\mathrm{D}^{*}\end{array}$ & $\mathrm{D}^{*}$ & & \\
\hline
\end{tabular}




\begin{tabular}{|c|c|c|c|c|c|c|c|c|c|c|c|c|}
\hline Crinum americanum & $\mathrm{D}$ & & $\mathrm{F}$ & $\mathrm{F}$ & $\begin{array}{l}\mathrm{F} \\
\mathrm{D}\end{array}$ & $\begin{array}{l}\mathrm{F} \\
\mathrm{D}\end{array}$ & $\begin{array}{l}\mathrm{F} \\
\mathrm{D}\end{array}$ & $\begin{array}{l}\mathrm{F} \\
\mathrm{D}\end{array}$ & $\mathrm{F}$ & $\mathrm{F}$ & & $\mathrm{D}$ \\
\hline $\begin{array}{c}\text { (Appendix A, continued) } \\
\text { SPECIES }\end{array}$ & $\mathbf{J}$ & $\mathbf{F}$ & $\mathbf{M}$ & $\mathbf{A}$ & $\mathbf{M}$ & $\mathbf{J}$ & $\mathbf{J}$ & $\mathbf{A}$ & $\mathbf{S}$ & $\mathbf{O}$ & $\mathbf{N}$ & $\mathbf{D}$ \\
\hline Helenium pinnatifidum & $\mathrm{F}$ & $\mathrm{F}$ & $\begin{array}{l}\mathrm{F} \\
\mathrm{D}\end{array}$ & $\begin{array}{l}\mathrm{F} \\
\mathrm{D}\end{array}$ & D & & & & & & & \\
\hline Hibiscus grandiflorus & & & & & $\mathrm{F}$ & $\mathrm{F}$ & $\begin{array}{l}\mathrm{F} \\
\mathrm{D}\end{array}$ & $\begin{array}{l}\mathrm{F} \\
\mathrm{D}\end{array}$ & D & $\mathrm{D}$ & D & \\
\hline Ipomoea sagittata & & & & $\mathrm{F}$ & & $\mathrm{F}$ & $\begin{array}{l}\mathrm{F} \\
\mathrm{D}\end{array}$ & $\begin{array}{l}\mathrm{F} \\
\mathrm{D}\end{array}$ & $\begin{array}{l}\mathrm{F} \\
\mathrm{D}\end{array}$ & $\mathrm{D}$ & $\mathrm{F}$ & \\
\hline Kosteletzkya virginica & & & & $\mathrm{F}$ & $\mathrm{F}$ & $\begin{array}{l}\mathrm{F} \\
\mathrm{D}\end{array}$ & $\begin{array}{l}\mathrm{F} \\
\mathrm{D}\end{array}$ & $\begin{array}{l}\mathrm{F} \\
\mathrm{D}\end{array}$ & $\mathrm{D}$ & & & \\
\hline Mikania scandens & $\mathrm{F}$ & & $\mathrm{F}$ & $\mathrm{F}$ & $\begin{array}{l}\mathrm{F} \\
\mathrm{D}\end{array}$ & $\begin{array}{l}\mathrm{F} \\
\mathrm{D}\end{array}$ & $\begin{array}{l}\mathrm{F} \\
\mathrm{D}\end{array}$ & $\begin{array}{l}\mathrm{F} \\
\mathrm{D}\end{array}$ & $\begin{array}{l}\mathrm{F} \\
\mathrm{D}\end{array}$ & $\begin{array}{l}\mathrm{F} \\
\mathrm{D}\end{array}$ & $\begin{array}{l}\mathrm{F} \\
\mathrm{D}\end{array}$ & $\begin{array}{l}\mathrm{F} \\
\mathrm{D}\end{array}$ \\
\hline Nuphar lutea & $\begin{array}{c}\mathrm{F} \\
\mathrm{D}^{\#}\end{array}$ & $\begin{array}{c}\mathrm{F} \\
\mathrm{D}^{\#}\end{array}$ & $\begin{array}{c}\mathrm{F} \\
\mathrm{D}^{\#}\end{array}$ & $\begin{array}{c}\mathrm{F} \\
\mathrm{D}^{\#}\end{array}$ & $\begin{array}{c}\mathrm{F} \\
\mathrm{D}^{\#}\end{array}$ & $\begin{array}{c}\mathrm{F} \\
\mathrm{D}^{\#}\end{array}$ & $\begin{array}{c}\mathrm{F} \\
\mathrm{D}^{\#}\end{array}$ & $\begin{array}{c}\mathrm{F} \\
\mathrm{D}^{\#}\end{array}$ & $\begin{array}{c}\mathrm{F} \\
\mathrm{D}^{\#}\end{array}$ & $\begin{array}{c}\mathrm{F} \\
\mathrm{D}^{\#}\end{array}$ & $\begin{array}{c}\mathrm{F} \\
\mathrm{D}^{\#}\end{array}$ & $\begin{array}{c}\mathrm{F} \\
\mathrm{D}^{\#}\end{array}$ \\
\hline Nymphoides aquatica & & & & & $\begin{array}{c}\mathrm{F} \\
\mathrm{D}^{\#}\end{array}$ & $\begin{array}{l}\mathrm{F} \\
\mathrm{D}^{\#}\end{array}$ & $\begin{array}{c}\mathrm{F} \\
\mathrm{D}^{\#}\end{array}$ & $\begin{array}{c}\mathrm{F} \\
\mathrm{D}^{\#}\end{array}$ & $\begin{array}{c}\mathrm{F} \\
\mathrm{D}^{\#}\end{array}$ & $\begin{array}{l}\mathrm{F} \\
\mathrm{D}^{\#}\end{array}$ & $\mathrm{D}^{\#}$ & \\
\hline Oxypolis filiformis & $\begin{array}{l}\mathrm{F} \\
\mathrm{D}\end{array}$ & $\begin{array}{l}\mathrm{F} \\
\mathrm{D}\end{array}$ & $\begin{array}{l}\mathrm{F} \\
\mathrm{D}\end{array}$ & $\begin{array}{l}\mathrm{F} \\
\mathrm{D}\end{array}$ & $\begin{array}{l}\mathrm{F} \\
\mathrm{D}\end{array}$ & $\begin{array}{l}\mathrm{F} \\
\mathrm{D}\end{array}$ & $\begin{array}{l}\mathrm{F} \\
\mathrm{D}\end{array}$ & $\begin{array}{l}\mathrm{F} \\
\mathrm{D}\end{array}$ & $\begin{array}{l}\mathrm{F} \\
\mathrm{D}\end{array}$ & $\begin{array}{l}\mathrm{F} \\
\mathrm{D}\end{array}$ & $\begin{array}{l}\mathrm{F} \\
\mathrm{D}\end{array}$ & $\begin{array}{l}\mathrm{F} \\
\mathrm{D}\end{array}$ \\
\hline Peltandra virginica & $\begin{array}{l}\mathrm{F} \\
\mathrm{D}\end{array}$ & & & $\mathrm{F}$ & $\begin{array}{l}\mathrm{F} \\
\mathrm{D}\end{array}$ & $\begin{array}{l}\mathrm{F} \\
\mathrm{D}\end{array}$ & $\begin{array}{l}\mathrm{F} \\
\mathrm{D}\end{array}$ & $\begin{array}{l}\mathrm{F} \\
\mathrm{D}\end{array}$ & $\begin{array}{l}\mathrm{F} \\
\mathrm{D}\end{array}$ & $\begin{array}{l}\mathrm{F} \\
\mathrm{D}\end{array}$ & $\begin{array}{l}\mathrm{F} \\
\mathrm{D}\end{array}$ & $\begin{array}{l}\mathrm{F} \\
\mathrm{D}\end{array}$ \\
\hline Pluchea rosea & $\mathrm{F}$ & $\begin{array}{l}\text { F } \\
D\end{array}$ & $\begin{array}{l}\mathrm{F} \\
\mathrm{D}\end{array}$ & $\begin{array}{l}\mathrm{F} \\
\mathrm{D}\end{array}$ & $\begin{array}{l}\text { F } \\
D\end{array}$ & $\begin{array}{l}\mathrm{F} \\
\mathrm{D}\end{array}$ & $\begin{array}{l}F \\
D\end{array}$ & $\begin{array}{l}\mathrm{F} \\
\mathrm{D}\end{array}$ & $\begin{array}{l}\mathrm{F} \\
\mathrm{D}\end{array}$ & D & & $\mathrm{F}$ \\
\hline Pontederia cordata & $\begin{array}{l}\text { F } \\
D\end{array}$ & $\begin{array}{l}\mathrm{F} \\
\mathrm{D}\end{array}$ & $\begin{array}{l}\mathrm{F} \\
\mathrm{D}\end{array}$ & $\begin{array}{l}\mathrm{F} \\
\mathrm{D}\end{array}$ & $\begin{array}{l}F \\
D \\
\end{array}$ & $\begin{array}{l}\mathrm{F} \\
\mathrm{D}\end{array}$ & $\begin{array}{l}\mathrm{F} \\
\mathrm{D} \\
\end{array}$ & $\begin{array}{l}\mathrm{F} \\
\mathrm{D}\end{array}$ & $\begin{array}{l}\mathrm{F} \\
\mathrm{D}\end{array}$ & $\begin{array}{l}\mathrm{F} \\
\mathrm{D}\end{array}$ & $\begin{array}{l}\mathrm{F} \\
\mathrm{D}\end{array}$ & $\begin{array}{l}\mathrm{F} \\
\mathrm{D}\end{array}$ \\
\hline Proserpinaca palustris & $\begin{array}{l}F \\
D\end{array}$ & $\begin{array}{l}F \\
D\end{array}$ & $\mathrm{D}$ & & $\bar{F}$ & $\begin{array}{l}\mathrm{F} \\
\mathrm{D}\end{array}$ & $\begin{array}{l}\mathrm{F} \\
\mathrm{D}\end{array}$ & $\mathrm{D}$ & & $\mathrm{F}$ & $\begin{array}{l}\mathrm{F} \\
\mathrm{D}\end{array}$ & $\begin{array}{l}\mathrm{F} \\
\mathrm{D}\end{array}$ \\
\hline Sagittaria lancifolia & $\begin{array}{l}F \\
D\end{array}$ & $\begin{array}{l}\mathrm{F} \\
\mathrm{D}\end{array}$ & $\begin{array}{l}\mathrm{F} \\
\mathrm{D}\end{array}$ & $\begin{array}{l}\mathrm{F} \\
\mathrm{D}\end{array}$ & $\begin{array}{l}\mathrm{F} \\
\mathrm{D}\end{array}$ & $\begin{array}{l}\mathrm{F} \\
\mathrm{D}\end{array}$ & $\begin{array}{l}\mathrm{F} \\
\mathrm{D}\end{array}$ & $\begin{array}{l}\mathrm{F} \\
\mathrm{D}\end{array}$ & $\begin{array}{l}\mathrm{F} \\
\mathrm{D}\end{array}$ & $\begin{array}{l}\mathrm{F} \\
\mathrm{D}\end{array}$ & $\begin{array}{l}\mathrm{F} \\
\mathrm{D}\end{array}$ & $\begin{array}{l}\mathrm{F} \\
\mathrm{D}\end{array}$ \\
\hline Symphyotrichum carolinianum & $\begin{array}{l}\mathrm{F} \\
\mathrm{D}\end{array}$ & $\begin{array}{l}\mathrm{F} \\
\mathrm{D}\end{array}$ & $\begin{array}{l}\mathrm{F} \\
\mathrm{D}\end{array}$ & $\begin{array}{l}\mathrm{F} \\
\mathrm{D}\end{array}$ & $\begin{array}{l}\mathrm{F} \\
\mathrm{D}\end{array}$ & $\begin{array}{l}\mathrm{F} \\
\mathrm{D}\end{array}$ & $\begin{array}{l}\mathrm{F} \\
\mathrm{D}\end{array}$ & D & & $F$ & $\begin{array}{l}\mathrm{F} \\
\mathrm{D}\end{array}$ & $\begin{array}{l}\mathrm{F} \\
\mathrm{D}\end{array}$ \\
\hline Thalia geniculata & $\begin{array}{c}\mathrm{F} \\
\mathrm{D}^{*}\end{array}$ & $\mathrm{D}^{*}$ & & & & $\mathrm{~F}$ & $F$ & $\begin{array}{c}\mathrm{F} \\
\mathrm{D}^{*}\end{array}$ & $\begin{array}{c}\mathrm{F} \\
\mathrm{D}^{*}\end{array}$ & $\begin{array}{c}\mathrm{F} \\
\mathrm{D}^{*}\end{array}$ & $\begin{array}{c}\mathrm{F} \\
\mathrm{D}^{*}\end{array}$ & $\begin{array}{c}\mathrm{F} \\
\mathrm{D}^{*}\end{array}$ \\
\hline Typha domingensis & & & $\mathrm{F}$ & $\mathrm{F}$ & $\begin{array}{l}\mathrm{F} \\
\mathrm{D}\end{array}$ & $\mathrm{D}$ & $\mathrm{D}$ & & & & & \\
\hline Utricularia gibba & $\begin{array}{l}\text { F } \\
D\end{array}$ & & $\mathrm{~F}$ & & $\mathrm{~F}$ & $\mathrm{~F}$ & $\mathrm{~F}$ & & & & $\begin{array}{l}\mathrm{F} \\
\mathrm{D}\end{array}$ & $\mathrm{F}$ \\
\hline Utricularia cornuta & $F$ & & $F$ & $\begin{array}{l}\mathrm{F} \\
\mathrm{D}\end{array}$ & $\begin{array}{l}\mathrm{F} \\
\mathrm{D}\end{array}$ & $\begin{array}{l}\mathrm{F} \\
\mathrm{D}\end{array}$ & $\begin{array}{l}\mathrm{F} \\
\mathrm{D}\end{array}$ & $\mathrm{F}$ & & & & \\
\hline Utricularia foliosa & $\begin{array}{l}\mathrm{F} \\
\mathrm{D}\end{array}$ & $\begin{array}{l}\mathrm{F} \\
\mathrm{D}\end{array}$ & $\begin{array}{l}\mathrm{F} \\
\mathrm{D}\end{array}$ & $\begin{array}{l}\mathrm{F} \\
\mathrm{D}\end{array}$ & $\begin{array}{l}\mathrm{F} \\
\mathrm{D}\end{array}$ & $\begin{array}{l}\mathrm{F} \\
\mathrm{D}\end{array}$ & $\begin{array}{l}\mathrm{F} \\
\mathrm{D}\end{array}$ & $\begin{array}{l}\mathrm{F} \\
\mathrm{D}\end{array}$ & $\begin{array}{l}\text { F } \\
D\end{array}$ & $\begin{array}{l}\mathrm{F} \\
\mathrm{D}\end{array}$ & $\begin{array}{l}\mathrm{F} \\
\mathrm{D}\end{array}$ & $\begin{array}{l}\mathrm{F} \\
\mathrm{D}\end{array}$ \\
\hline Utricularia purpurea & & & $\bar{F}$ & $\begin{array}{l}\mathrm{F} \\
\mathrm{D}\end{array}$ & $\begin{array}{l}\mathrm{F} \\
\mathrm{D}\end{array}$ & $\begin{array}{l}\mathrm{F} \\
\mathrm{D}\end{array}$ & $\begin{array}{l}\mathrm{F} \\
\mathrm{D}\end{array}$ & $\begin{array}{l}\mathrm{F} \\
\mathrm{D}\end{array}$ & $\begin{array}{l}\mathrm{F} \\
\mathrm{D}\end{array}$ & $\begin{array}{l}\mathrm{F} \\
\mathrm{D}\end{array}$ & $\mathrm{F}$ & $\mathrm{F}$ \\
\hline Utricularia resupinata & $\mathrm{D}$ & & $\mathrm{F}$ & $\begin{array}{c}\mathrm{F} \\
\mathrm{D}^{*}\end{array}$ & $\mathrm{D}^{*}$ & & & & & & & $\begin{array}{c}\mathrm{F} \\
\mathrm{D}^{*}\end{array}$ \\
\hline $\begin{array}{l}3 \text { - WOODY TEMPERATE } \\
(\mathrm{n}=7)\end{array}$ & & & & & & & & & & & & \\
\hline Cephalanthus occidentalis & & & & $\mathrm{F}$ & $\bar{F}$ & $\mathrm{~F}$ & $\begin{array}{c}\mathrm{F} \\
\mathrm{D}^{*}\end{array}$ & $\begin{array}{c}\mathrm{F} \\
\mathrm{D}^{*}\end{array}$ & $\mathrm{D}^{*}$ & & & \\
\hline Ilex cassine var. cassine & $\mathrm{F}$ & & & $\mathrm{F}$ & $\mathrm{F}$ & & & & & & & \\
\hline
\end{tabular}




\begin{tabular}{|c|c|c|c|c|c|c|c|c|c|c|c|c|}
\hline & & & & $\mathrm{D}$ & & & & $\mathrm{D}^{*}$ & $\mathrm{D}^{*}$ & $\mathrm{D}^{*}$ & $\mathrm{D}^{*}$ & $\mathrm{D}^{*}$ \\
\hline Magnolia virginiana & & & F & $\mathrm{F}$ & $\mathrm{F}$ & $\mathrm{F}$ & $\mathrm{F}$ & & $\mathrm{D}$ & $\mathrm{D}$ & $\mathrm{D}$ & $\mathrm{D}$ \\
\hline $\begin{array}{c}\text { (Appendix A, continued) } \\
\text { SPECIES }\end{array}$ & $\mathbf{J}$ & $\mathbf{F}$ & $\mathbf{M}$ & $\mathbf{A}$ & $\mathbf{M}$ & $\mathbf{J}$ & $\mathbf{J}$ & $\mathbf{A}$ & $\mathbf{S}$ & $\mathbf{O}$ & $\mathbf{N}$ & D \\
\hline Morella (Myrica) cerifera & $\mathrm{F}$ & $\mathrm{F}$ & $\mathrm{F}$ & $\mathrm{F}$ & $\mathrm{F}$ & $\mathrm{F}$ & $\mathrm{D}$ & $\mathrm{D}$ & $\mathrm{D}$ & $\mathrm{D}$ & $\mathrm{D}$ & \\
\hline Persea borbonia var. borbonia & & & & $\mathrm{F}$ & $\mathrm{F}$ & $\mathrm{F}$ & $\mathrm{F}$ & $\mathrm{F}$ & & & $\mathrm{D}^{*}$ & $\mathrm{D}^{*}$ \\
\hline Salix caroliniana & $\begin{array}{l}\mathrm{F} \\
\mathrm{D}\end{array}$ & $\begin{array}{l}\mathrm{F} \\
\mathrm{D}\end{array}$ & $\mathrm{D}$ & & & & & & & & & \\
\hline Sambucus nigra subsp. canadensis & $\begin{array}{l}\mathrm{F} \\
\mathrm{D}\end{array}$ & $\begin{array}{l}\mathrm{F} \\
\mathrm{D}\end{array}$ & $\begin{array}{l}\mathrm{F} \\
\mathrm{D}\end{array}$ & $\begin{array}{l}\mathrm{F} \\
\mathrm{D}\end{array}$ & $\begin{array}{l}\mathrm{F} \\
\mathrm{D}\end{array}$ & $\begin{array}{l}\mathrm{F} \\
\mathrm{D}\end{array}$ & $\begin{array}{l}\mathrm{F} \\
\mathrm{D}\end{array}$ & $\begin{array}{l}\mathrm{F} \\
\mathrm{D}\end{array}$ & $\begin{array}{l}\mathrm{F} \\
\mathrm{D}\end{array}$ & $\begin{array}{l}\mathrm{F} \\
\mathrm{D}\end{array}$ & $\begin{array}{l}\mathrm{F} \\
\mathrm{D}\end{array}$ & $\begin{array}{l}\mathrm{F} \\
\mathrm{D}\end{array}$ \\
\hline 4 - WOODY TROPICAL $(n=3)$ & & & & & & & & & & & & \\
\hline Annona glabra & & & & $\mathrm{F}$ & $\mathrm{F}$ & $\mathrm{F}$ & & $\mathrm{D}^{*}$ & $\mathrm{D}^{*}$ & & & \\
\hline Chrysobalanus icaco & $\begin{array}{c}\mathrm{F} \\
\mathrm{D}^{*}\end{array}$ & $\begin{array}{c}\mathrm{F} \\
\mathrm{D}^{*}\end{array}$ & $\begin{array}{c}\mathrm{F} \\
\mathrm{D}^{*}\end{array}$ & $\begin{array}{c}\mathrm{F} \\
\mathrm{D}^{*}\end{array}$ & $\begin{array}{c}\mathrm{F} \\
\mathrm{D}^{*}\end{array}$ & $\begin{array}{c}\mathrm{F} \\
\mathrm{D}^{*}\end{array}$ & $\begin{array}{c}\mathrm{F} \\
\mathrm{D}^{*}\end{array}$ & $\begin{array}{c}\mathrm{F} \\
\mathrm{D}^{*}\end{array}$ & $\begin{array}{c}\mathrm{F} \\
\mathrm{D}^{*}\end{array}$ & $\begin{array}{c}\mathrm{F} \\
\mathrm{D}^{*}\end{array}$ & $\begin{array}{c}\mathrm{F} \\
\mathrm{D}^{*}\end{array}$ & $\begin{array}{c}\mathrm{F} \\
\mathrm{D}^{*}\end{array}$ \\
\hline Dalbergia ecastophyllum & $\begin{array}{l}\mathrm{F} \\
\mathrm{D}\end{array}$ & $\mathrm{F}$ & $\mathrm{F}$ & $\mathrm{F}$ & $\mathrm{F}$ & $\mathrm{F}$ & $\mathrm{F}$ & & & & & $\mathrm{D}$ \\
\hline $\begin{array}{c}\text { SUM FOR ALL SPECIES } \\
(\text { F/D })(n=51)\end{array}$ & $\begin{array}{l}26 \\
25\end{array}$ & $\begin{array}{l}19 \\
16\end{array}$ & $\begin{array}{l}28 \\
19 \\
\end{array}$ & $\begin{array}{l}38 \\
21 \\
\end{array}$ & $\begin{array}{l}43 \\
25 \\
\end{array}$ & $\begin{array}{l}43 \\
32 \\
\end{array}$ & $\begin{array}{l}41 \\
38 \\
\end{array}$ & $\begin{array}{l}35 \\
39 \\
\end{array}$ & $\begin{array}{l}29 \\
36 \\
\end{array}$ & $\begin{array}{l}\mathbf{2 8} \\
\mathbf{3 3} \\
\end{array}$ & $\begin{array}{l}27 \\
31 \\
\end{array}$ & $\begin{array}{l}24 \\
29 \\
\end{array}$ \\
\hline
\end{tabular}


Appendix B. Everglades species evaluated $(n=51)$ for season of dispersal. 1 = Early wet season (May-August); 2 = Late wet season (September-January); 3 = Throughout flooding (May-January); 4 = Dry substrate (February-April); 5 = General, all year.

\begin{tabular}{|c|c|c|}
\hline SPECIES & FAMILY & \begin{tabular}{|c|} 
Dispersal \\
Season
\end{tabular} \\
\hline Annona glabra L. & Annonaceae & 1 \\
\hline Asclepias lanceolata Walter & Apocyanaceae & 1 \\
\hline Cladium jamaicense Crantz & Cyperaceae & 1 \\
\hline Rhynchospora tracyi Britton & Cyperaceae & 1 \\
\hline Utricularia cornuta Michx. & Lentibulariaceae & 1 \\
\hline Utricularia resupinata B.D. Greene ex Bigelow & Lentibulariaceae & 1 \\
\hline Kosteletzkya virginica (L.) C. Presl. ex A. Gray & Malvaceae & 1 \\
\hline Cephalanthus occidentalis L. & Rubiaceae & 1 \\
\hline Typha domingensis Pers. & Typhaceae & 1 \\
\hline Boehmeria cylindrica (L.) Sw. & Urticaceae & 1 \\
\hline Ilex cassine var. cassine L. & Aquifoliaceae & 2 \\
\hline Canna flaccida Salisb. & Cannaceae & 2 \\
\hline Ipomoea sagittata Poir. & Convolvulaceae & 2 \\
\hline Bulbostylis ciliatifolia (Elliott) Fernald & Cyperaceae & 2 \\
\hline Cyperus odoratus L. & Cyperaceae & 2 \\
\hline Eleocharis cellulosa Torr. & Cyperaceae & 2 \\
\hline Eleocharis interstincta (Vahl) Roem.\& Schult. & Cyperaceae & 2 \\
\hline Rhynchospora inundata (Oakes) Fernald & Cyperaceae & 2 \\
\hline Dalbergia ecastophyllum (L.) Taub & Fabaceae & 2 \\
\hline Persea borbonia var. borbonia (L.) Spreng & Lauraceae & 2 \\
\hline Utricularia gibba $\mathrm{L}$. & Lentibulariaceae & 2 \\
\hline Magnolia virginiana $\mathrm{L}$. & Magnoliaceae & 2 \\
\hline Hibiscus grandiflorus Michx. & Malvaceae & 2 \\
\hline Thalia geniculata L. & Marantaceae & 2 \\
\hline Morella (Myrica) cerifera $\mathrm{L}$ & Myricaceae & 2 \\
\hline Dichanthelium dichotomum (L.) Gould & Poaceae & 2 \\
\hline Salix caroliniana Michx. & Salicaceae & 2 \\
\hline Peltandra virginica (L.) Schott. & Araceae & 3 \\
\hline Mikania scandens (L.) Willd. & Asteraceae & 3 \\
\hline Fuirena breviseta (Coville) Coville & Cyperaceae & 3 \\
\hline Scleria verticillata Muhl. ex Willd. & Cyperaceae & 3 \\
\hline Proserpinaca palustris L. & Haloragaceae & 3 \\
\hline Juncus megacephalus M.A. Curtis & Juncaginaceae & 3 \\
\hline Utricularia purpurea Walter & Lentibulariaceae & 3 \\
\hline Nymphoides aquatica (J.F. Gemel.) Kuntze & Menyanthaceae & 3 \\
\hline Panicum hemitomon Schult. & Poaceae & 3 \\
\hline Helenium pinnatifidum (Schwein ex Nutt.) Ryab. & Asteraceae & 4 \\
\hline Sambucus nigra subsp. canadensis (L.) R. Bolli. & Adoxaceae & 5 \\
\hline Sagittaria lancifolia $\mathrm{L}$. & Alismataceae & 5 \\
\hline Oxypolis filiformis (Walter) Britton & Apiaceae & 5 \\
\hline
\end{tabular}




\begin{tabular}{|l|l|c|}
\hline (Appendix B, continued) SPECIES & \multicolumn{1}{|c|}{ FAMILY } & $\begin{array}{c}\text { Dispersal } \\
\text { Season }\end{array}$ \\
\hline Pluchea rosea R.K. Godfrey & Asteraceae & 5 \\
\hline $\begin{array}{l}\text { Symphyotrichum carolinianum (Walter) Wunderlin } \\
\text { \& B.F. Hansen }\end{array}$ & Asteraceae & 5 \\
\hline Chrysobalanus icaco L. & Chrysobalanaceae & 5 \\
\hline Rhynchospora colorata (L.) H. Pfeiff. & Cyperaceae & 5 \\
\hline Rhynchospora microcarpa Baldwin ex A. Gray & Cyperaceae & 5 \\
\hline Aeschynomene pratensis Small & Fabaceae & 5 \\
\hline Utricularia foliosa L. & Lentibulariaceae & 5 \\
\hline Crinum americanum L. & Liliaceae & 5 \\
\hline Nuphar lutea L.) Sm. & Nymphaeaceae & 5 \\
\hline Agalinis linifolia (Nutt.) Britton & Orobanchaceae & 5 \\
\hline Pontederia cordata L. & Pontederiaceae & 5 \\
\hline
\end{tabular}


Appendix C. Species traits related to diaspore dispersal in flowering plants of Shark River Slough, ENP. Dispersal Season is defined as: 1= Early Wet, MJJA; 2= Late Wet, SONDJ; $3=$ Throughout Wet, MJJASONDJ; 4= Dry substrate, FMA; 5= General, all year. Abbreviations as follows: Diasp. $=$ diaspore; Len. =length; Buoy. = buoyancy.

\begin{tabular}{|c|c|c|c|c|c|c|c|c|}
\hline Species & $\begin{array}{l}\text { Dispersal } \\
\text { Unit }\end{array}$ & $\begin{array}{l}\text { Mean } \\
\text { Seed } \\
\text { Mass } \\
(\mathrm{mg}) \\
\end{array}$ & $\begin{array}{l}\text { Mean } \\
\text { Diasp. } \\
\text { Mass } \\
(\mathrm{mg}) \\
\end{array}$ & $\begin{array}{l}\text { Mean } \\
\text { Seed } \\
\text { Len. } \\
(\mathrm{mm})\end{array}$ & $\begin{array}{l}\text { Mean } \\
\text { Diasp. } \\
\text { Len. } \\
(\mathrm{mm})\end{array}$ & $\begin{array}{l}\text { Mean } \\
\text { Seed } \\
\text { Buoy. } \\
\left(\mathrm{FD}_{50}\right)\end{array}$ & $\begin{array}{l}\text { Mean } \\
\text { Diasp. } \\
\text { Buoy. } \\
\left(\mathrm{FD}_{50}\right)\end{array}$ & $\begin{array}{l}\text { Diasp. } \\
\text { Season }\end{array}$ \\
\hline \multicolumn{9}{|l|}{ GRAMINOIDS } \\
\hline Bulbostylis ciliatifolia & Achene & 0.40 & 0.40 & 0.9 & 0.9 & & & 2 \\
\hline Cladium jamaicense & Achene & 2.71 & 5.90 & 3.0 & 3.0 & 12 & 12 & 1 \\
\hline Cyperus odoratus & Achene + style & 0.05 & 0.05 & 1.0 & 1.0 & 3 & 3 & 2 \\
\hline \begin{tabular}{|l|} 
Dichanthelium \\
dichotomum
\end{tabular} & Grain + glumes & 0.29 & 0.69 & 2.0 & & 3 & 3 & 2 \\
\hline Eleocharis cellulosa & $\begin{array}{c}\text { Achene + } \\
\text { bristles }\end{array}$ & 1.28 & 1.28 & 2.8 & 2.8 & 4 & 9 & 2 \\
\hline Eleocharis interstincta & $\begin{array}{l}\text { Achene + long } \\
\text { bristles, curly } \\
\text { style }\end{array}$ & 1.20 & & 2.2 & & 1 & 2 & 2 \\
\hline Fuirena breviseta & $\begin{array}{c}\text { Achene }+ \\
\text { perianth scales }\end{array}$ & 0.22 & 0.22 & 1.6 & 2.0 & & 30 & 3 \\
\hline Juncus megacephalus & $\begin{array}{c}\text { Capsule + } \\
\text { perianth }\end{array}$ & 0.09 & 0.09 & 0.7 & 0.7 & 1 & 1 & 3 \\
\hline Panlcum hemitomon & Grain + allied & 0.23 & 0.85 & 1.3 & & 5 & 3 & 3 \\
\hline Rhynchospora colorata & Achene & 0.94 & 0.94 & 1.2 & 1.2 & 1 & 1 & 5 \\
\hline Rhynchospora inundata & $\begin{array}{l}\text { Achene + } \\
\text { tubercle }\end{array}$ & 13.7 & 13.7 & 23.7 & 23.7 & 30 & 30 & 2 \\
\hline Rhynchospora microcarpa & $\begin{array}{c}\text { Achene }+ \\
\text { Short bristles }\end{array}$ & 0.25 & 0.25 & 1.4 & 1.4 & 1 & 1 & 5 \\
\hline Rhynchospora tracyi & $\begin{array}{c}\text { Achene + long, } \\
\text { bristles \& } \\
\text { tubercle }\end{array}$ & 1.85 & 1.85 & 6.0 & 6.0 & 3 & 3 & 1 \\
\hline Scleria verticillata & Achene & 0.84 & 0.84 & 1.2 & 1.2 & 1 & 1 & 3 \\
\hline \multicolumn{9}{|l|}{ FORBS } \\
\hline $\begin{array}{l}\text { Aeschynomene pratensis } \\
\text { var. pratensis }\end{array}$ & Loment section & 17.2 & 25.2 & 4.1 & 6.5 & 1 & 30 & 5 \\
\hline Agalinis linifolia & seed & 0.43 & 0.43 & 0.6 & 0.6 & 6 & 6 & 5 \\
\hline Asclepias lanceolata & Comose seed & 4.78 & 4.78 & 11.9 & 11.9 & 8 & 8 & 1 \\
\hline Boehmeria cylindrica & $\begin{array}{c}\text { Achene covered } \\
\text { by calyx }\end{array}$ & 0.68 & 0.68 & 0.9 & 0.9 & 30 & 30 & 1 \\
\hline Canna flaccida & capsule & 193.1 & & 6.0 & 6.0 & 1 & & 2 \\
\hline Crinum americanum & seed & 5.71 & & & & & 1 & 5 \\
\hline Helenium pinnatifidum & $\begin{array}{l}\text { Pubescent } \\
\text { achene }\end{array}$ & 0.37 & 0.37 & 1.3 & 1.3 & & & 4 \\
\hline
\end{tabular}




\begin{tabular}{|c|c|c|c|c|c|c|c|c|}
\hline \begin{tabular}{|c|} 
(Appendix C, continued) \\
Species
\end{tabular} & $\begin{array}{l}\text { Dispersal } \\
\text { Unit }\end{array}$ & $\begin{array}{c}\text { Mean } \\
\text { Seed } \\
\text { Mass } \\
(\mathrm{mg}) \\
\end{array}$ & \begin{tabular}{|l|} 
Mean \\
Diasp. \\
Mass \\
$(\mathrm{mg})$ \\
\end{tabular} & $\begin{array}{l}\text { Mean } \\
\text { Seed } \\
\text { Len. } \\
(\mathrm{mm}) \\
\end{array}$ & $\begin{array}{l}\text { Mean } \\
\text { Diasp. } \\
\text { Len. } \\
(\mathrm{mm})\end{array}$ & $\begin{array}{c}\text { Mean } \\
\text { Seed } \\
\text { Buoy. } \\
\left(\mathrm{FD}_{50}\right) \\
\end{array}$ & $\begin{array}{l}\text { Mean } \\
\text { Diasp. } \\
\text { Buoy. } \\
\left(F_{50}\right)\end{array}$ & $\begin{array}{l}\text { Diasp. } \\
\text { Seasor }\end{array}$ \\
\hline Hibiscus grandiflorus & Seed & 8.13 & 8.13 & 2.8 & 2.8 & 30 & 30 & 2 \\
\hline Ipomoea sagittata & Pilose seed & 4.70 & 4.70 & 6.5 & 6.5 & & & 2 \\
\hline Kosteletzkya virginica & Seed & 9.80 & 9.80 & 2.9 & 2.9 & 30 & 30 & 1 \\
\hline Mikania scandens & $\begin{array}{c}\text { Achene + } \\
\text { bristled pappus }\end{array}$ & 0.06 & 0.06 & 1.9 & & & & 3 \\
\hline Nymphaea odorata & seeds & & & 1.8 & & & & \\
\hline Nymphoides aquatica & $\begin{array}{c}\text { Fruit + floating } \\
\text { leaf }\end{array}$ & & & & & & & 3 \\
\hline Oxypolis filiformis & Winged capsule & 3.0 & 3.0 & 6.5 & 6.5 & 30 & 30 & 5 \\
\hline Peltandra virginica & Berry & & 1204 & 2.0 & & & 1 & 3 \\
\hline Pluchea rosea & $\begin{array}{c}\text { Achene + } \\
\text { pappus }\end{array}$ & 2.8 & 2.8 & 0.4 & 0.4 & & & 5 \\
\hline Pontederia cordata & Utricle & 3.1 & 30.0 & 4.3 & & 15 & 15 & 5 \\
\hline Proserpinaca palustris & achene & 13.2 & 13.2 & 3.5 & 3.5 & 30 & 30 & 3 \\
\hline Sagittaria lancifolia & Achene & 1.0 & 1.0 & 2.6 & 2.6 & 4 & 4 & 5 \\
\hline $\begin{array}{l}\text { Symphyotrichum } \\
\text { carolinianum }\end{array}$ & Achene & 0.14 & 0.22 & 1.6 & 1.7 & & & 5 \\
\hline Thalia geniculata & Buoyant utricle & 171 & & 7.0 & & 1 & 2 & 2 \\
\hline Typha domingensis & Fruit + allied & & & 5.2 & & & & 1 \\
\hline Utricularia gibba & Seed & & & 0.8 & 0.8 & & & 2 \\
\hline Utricularia foliosa & Fleshy capsule & & 36.1 & & & & & 5 \\
\hline Utricularia purpurea & seed & & & & & & & 3 \\
\hline Utricularia resupinata & Seed & 0.02 & 0.02 & 0.3 & 0.3 & & & 1 \\
\hline Utriculata cornuta & seed & & & & & & & 1 \\
\hline \multicolumn{9}{|l|}{ WOODY TEMPERATE } \\
\hline Cephalanthus occidentalis & fruit + calyx & 3.80 & 3.80 & 5.1 & 5.1 & & 30 & 1 \\
\hline Ilex cassine var. cassine & $\begin{array}{c}\text { Drupe with } 2-4 \\
\text { seeds }\end{array}$ & 2.70 & 125 & 2.7 & 6.8 & 30 & 30 & 2 \\
\hline Magnolia virginiana & Seed + aril & 82.5 & & 8.8 & & 1 & 1 & 2 \\
\hline Morella cerifera & $\begin{array}{c}\text { Drupe with 2-3 } \\
\text { seeds }\end{array}$ & 12.6 & 33.0 & 2.8 & 3.3 & 1 & 1 & 2 \\
\hline $\begin{array}{l}\text { Persea borbonia var. } \\
\text { borbonia }\end{array}$ & Drupe & 188 & & 8.9 & & 1 & 1 & 2 \\
\hline Salix caroliniana & $\begin{array}{c}\text { Capsule with } \\
\text { hairs } \\
\end{array}$ & & 0.18 & & 1.4 & & 4 & 2 \\
\hline $\begin{array}{l}\text { Sambucus nigra subsp. } \\
\text { canadensis }\end{array}$ & $\begin{array}{c}\text { Berry-like } \\
\text { drupe with 3-5 } \\
\text { seeds }\end{array}$ & 1.35 & & 3.2 & & 10 & 10 & 5 \\
\hline \multicolumn{9}{|l|}{ WOODY TROPICAL } \\
\hline Annona glabra & fruit & 186 & & 15 & 100 & 30 & 30 & 1 \\
\hline Chrysobalanus icaco & Drupe & 547 & & 15.2 & & 30 & 30 & 5 \\
\hline palbergia ecastophyllum & $\begin{array}{c}\text { Winged 1- } \\
\text { seeded legume }\end{array}$ & & 371 & & 24.6 & & 30 & 2 \\
\hline
\end{tabular}


APPENDIX D. Seed and diaspore photographs with dispersal information. This Seed Atlas was generated to serve as an identification reference during Everglades seed research (2003 2008). It consists of those species that were encountered during monthly visits to the northwestern edge of Shark River Slough, Everglades National Park. Each species is represented by one or more photographs taken alongside a ruler with $1 \mathrm{~mm}$ divisions. $\mathrm{FD}_{50}$ is the time in days for half of the dispersal unit to sink. Diaspore $=$ seed and allied matter.

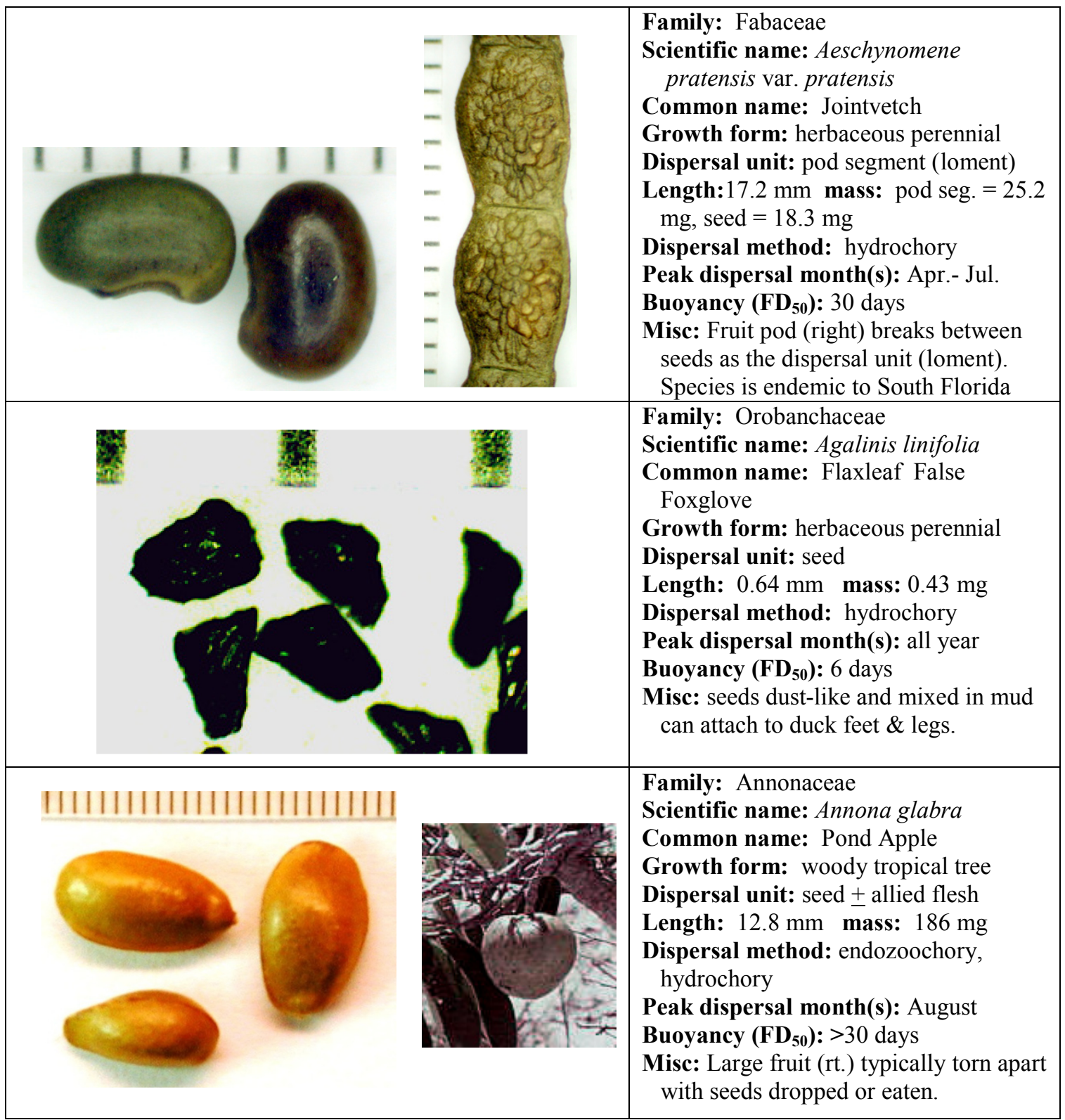




\begin{tabular}{|c|c|}
\hline Noly 11111111 & $\begin{array}{l}\text { Family: Apocyanaceae } \\
\text { Scientific name: Asclepias lanceolata } \\
\text { Common name: Fewflower Milkweed } \\
\text { Growth form: herbaceous perennial } \\
\text { Dispersal unit: comose seed } \\
\text { Length: } 11.9 \text { mm mass: } 4.8 \mathrm{mg} \\
\text { Dispersal method: anemochory, } \\
\text { hydrochory } \\
\text { Peak dispersal month(s): June, July } \\
\text { Buoyancy: } 8 \text { days } \\
\text { Misc: Comose matter readily falls off } \\
\text { after impact, but seed very buoyant. }\end{array}$ \\
\hline 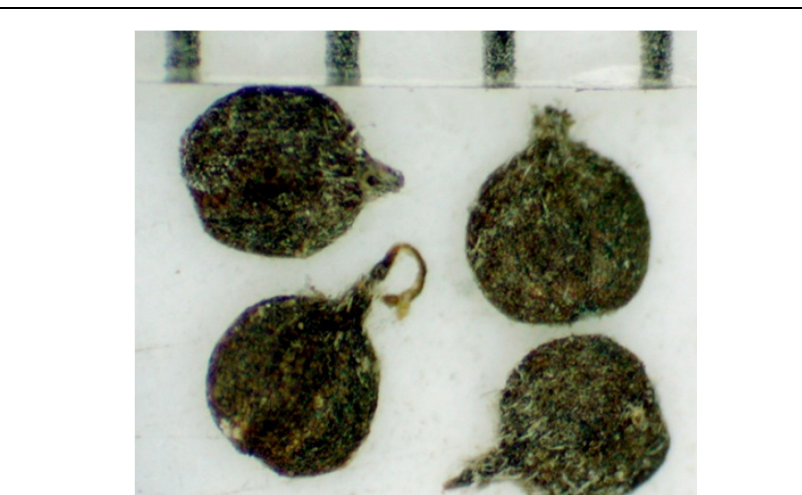 & $\begin{array}{l}\text { Family: Urticaceae } \\
\text { Scientific name: Boehmeria cylindrica } \\
\text { Common name: False Nettle; Bog } \\
\quad \text { Hemp } \\
\text { Growth form: herbaceous perennial } \\
\text { Dispersal unit: fruit (achene) } \\
\text { Length: } 0.88 \mathrm{~mm} \text { mass: } 0.68 \mathrm{mg} \\
\text { Dispersal method: hydrochory } \\
\text { Peak dispersal month(s): Aug., Sept. } \\
\text { Buoyancy (FD } \text { Fo }_{\mathbf{5 0}} \text { ): }>30 \text { days } \\
\text { Misc: fruit mixed in mud cann attaches } \\
\text { to duck feet \& legs. }\end{array}$ \\
\hline & $\begin{array}{l}\text { Family: Cannaceae } \\
\text { Scientific name: Canna flaccida } \\
\text { Common name: Bandana of the } \\
\text { Everglades } \\
\text { Growth form: herbaceous perennial } \\
\text { Dispersal unit: fruit (capsule, } \\
\text { left: } 3.8 \times 2.0 \mathrm{~cm} \text { ) or seed } \\
\text { Length: } 6.0 \mathrm{~mm}(\mathrm{~s} .) \text { mass: } 193.1 \mathrm{mg}(\mathrm{s}) \\
\text { Dispersal method: hydrochory } \\
\text { Peak dispersal month(s): Sept., Oct. } \\
\left.\text { Buoyancy (FD } \text { Fo }_{50}\right):<1 \text { day (seed) } \\
\text { Misc: Capsules with air chambers in } \\
\text { walls (buoyant) each with } 6+\text { seeds. }\end{array}$ \\
\hline & $\begin{array}{l}\text { Family: Rubiaceae } \\
\text { Scientific name: Cephalanthus } \\
\text { occidentalis } \\
\text { Common name: Buttonbush } \\
\text { Growth form: woody temperate shrub } \\
\text { Dispersal unit: fruit + calyx } \\
\text { Length: } 5.1 \mathrm{~mm} \text { mass: } 3.8 \mathrm{mg} \\
\text { Dispersal method: hydrochory, } \\
\text { endozoochory } \\
\text { Peak dispersal month(s):July - Sept. } \\
\text { Buoyancy (FD } \text { Fo }_{\text {50 }}>30 \text { days } \\
\text { Misc: Large end of fruit with suberose } \\
\text { cells allow floating, calyx end with } \\
\text { apparent sweet attractant. }\end{array}$ \\
\hline
\end{tabular}




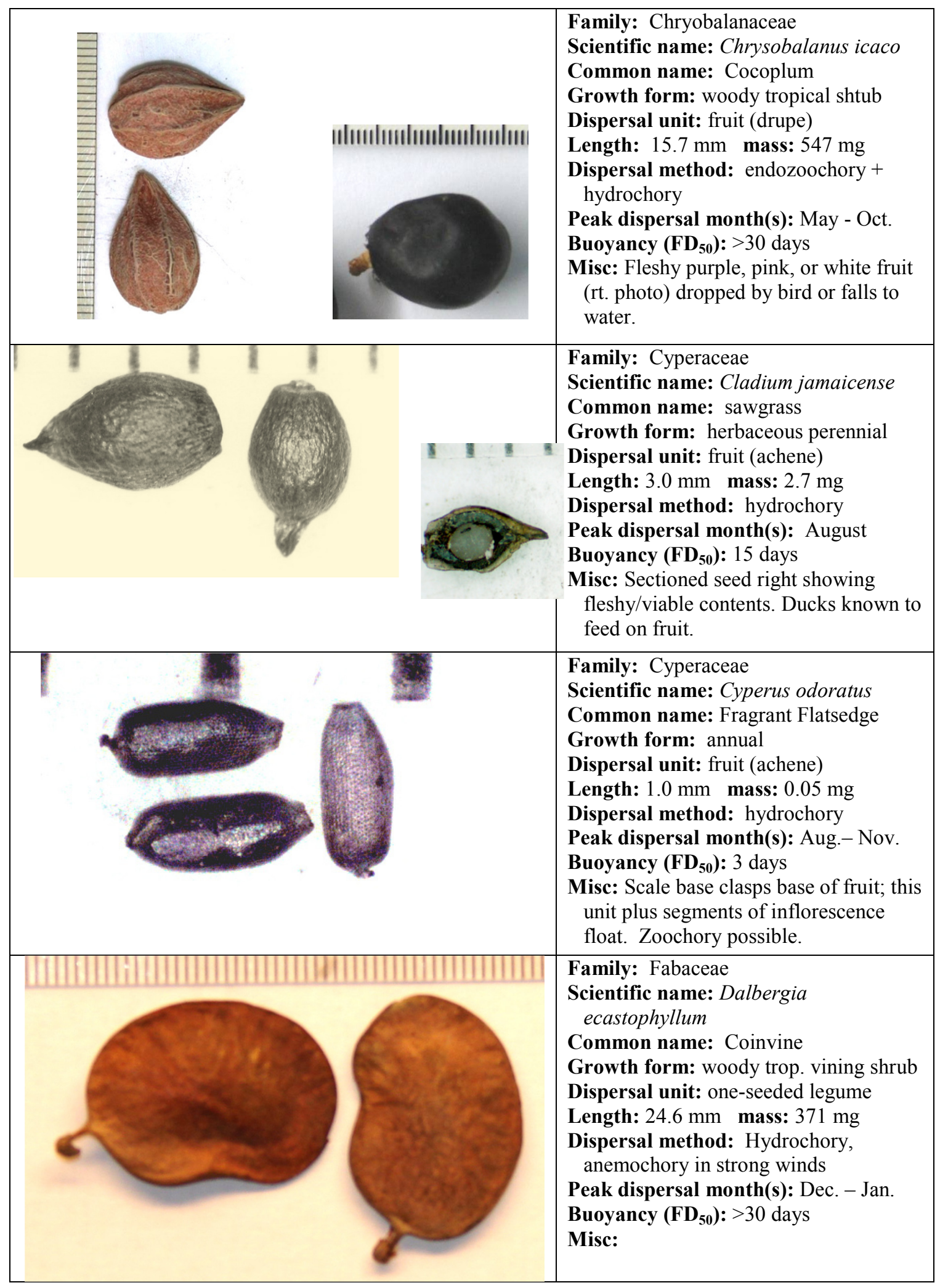




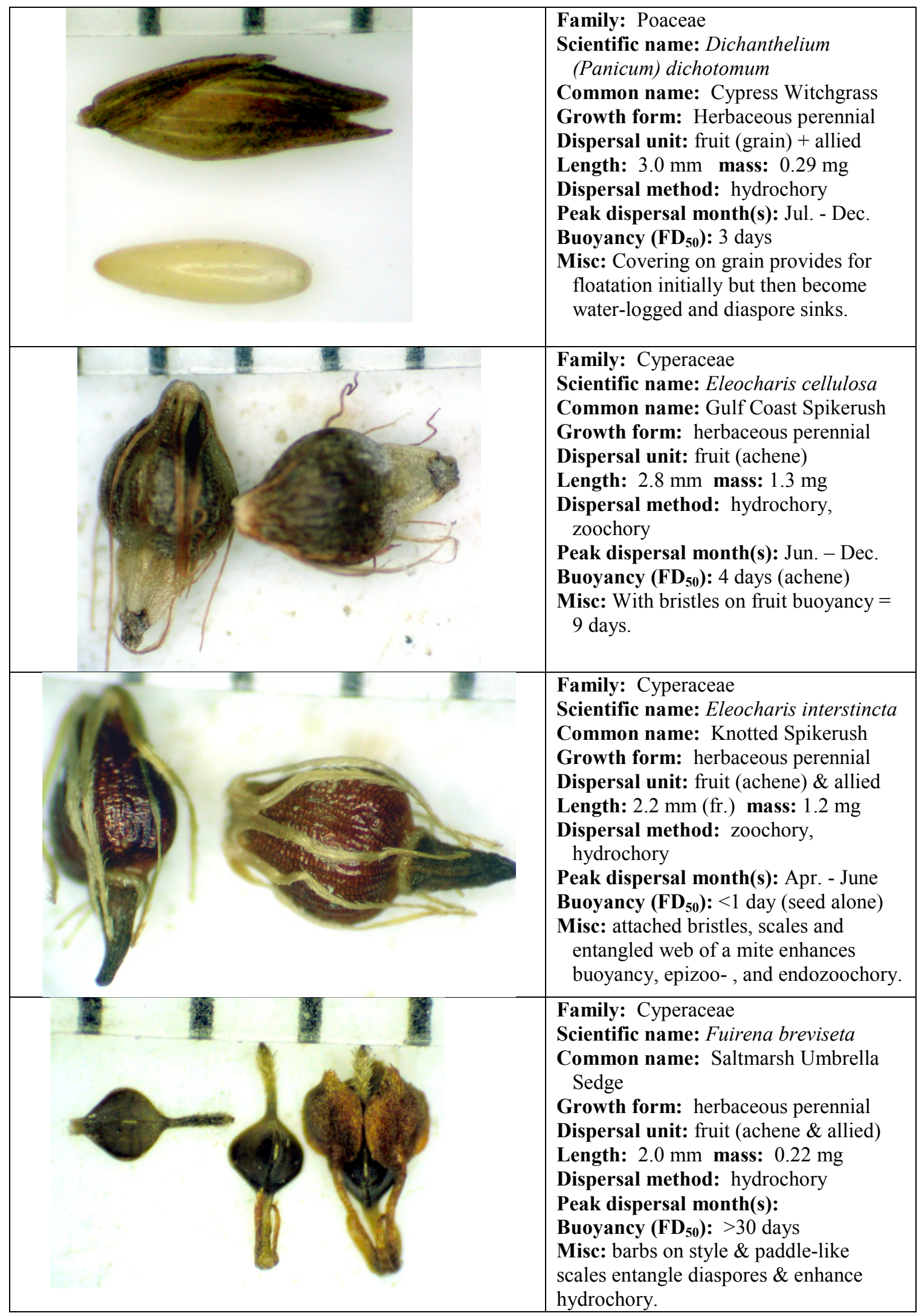




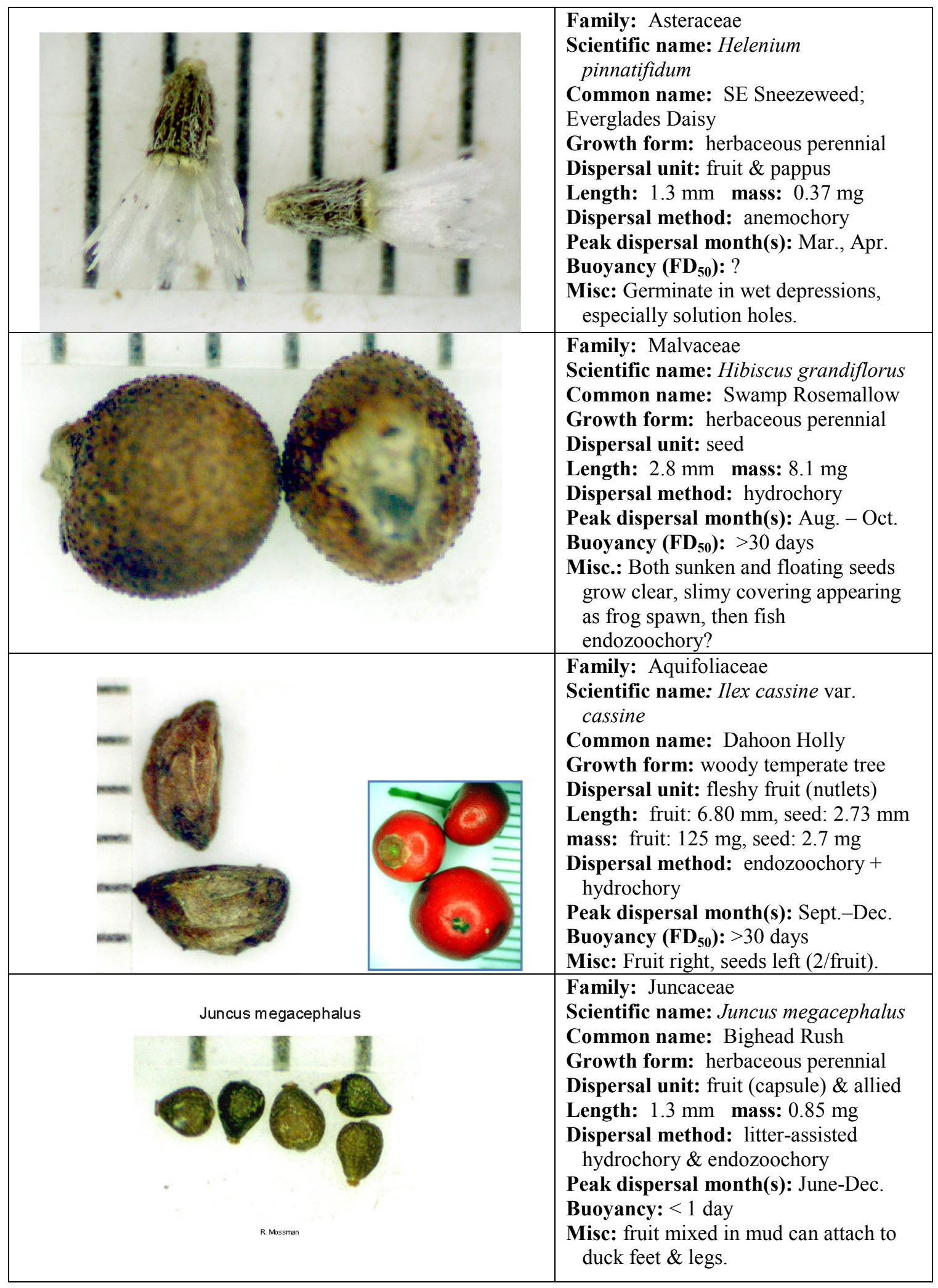




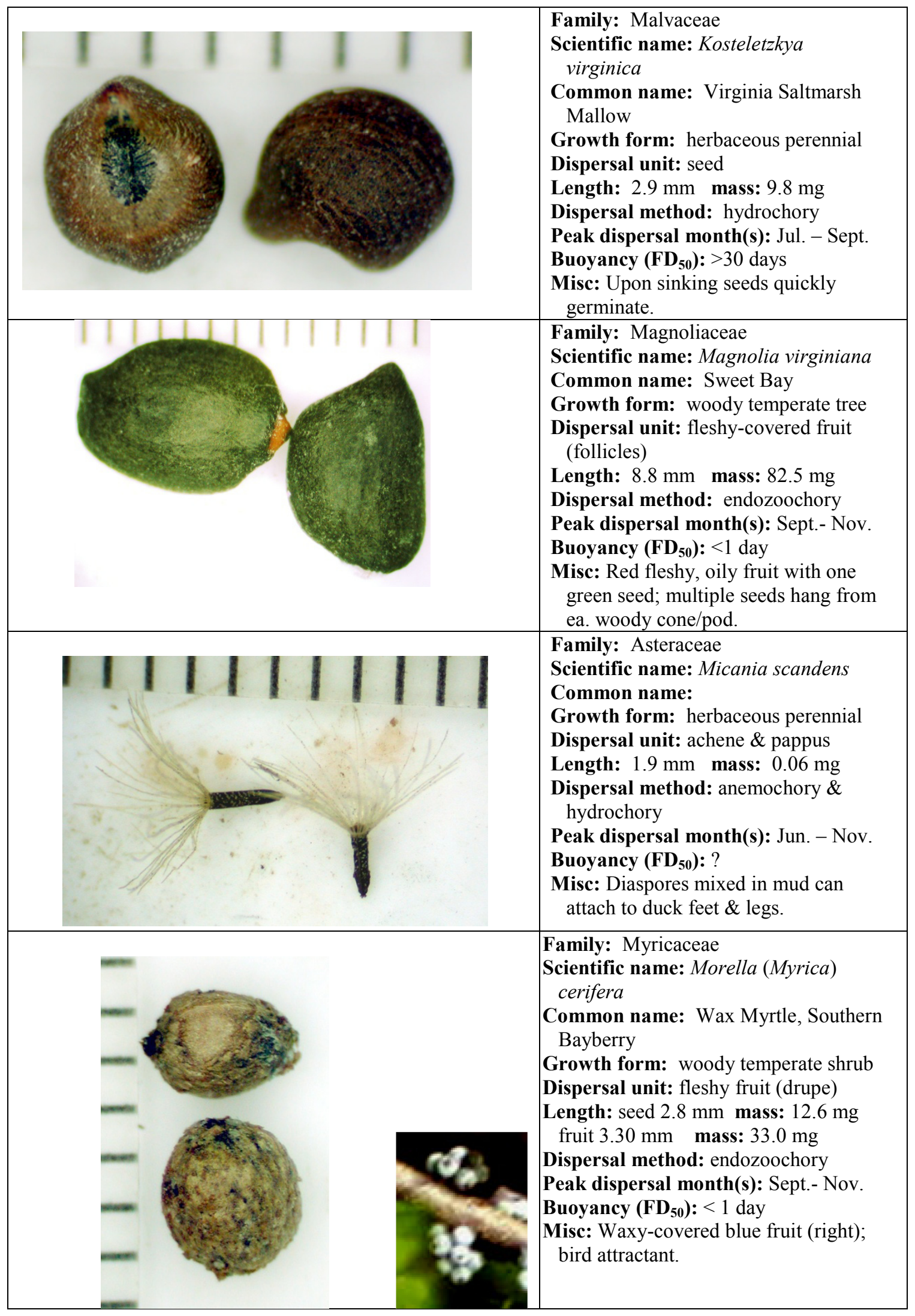




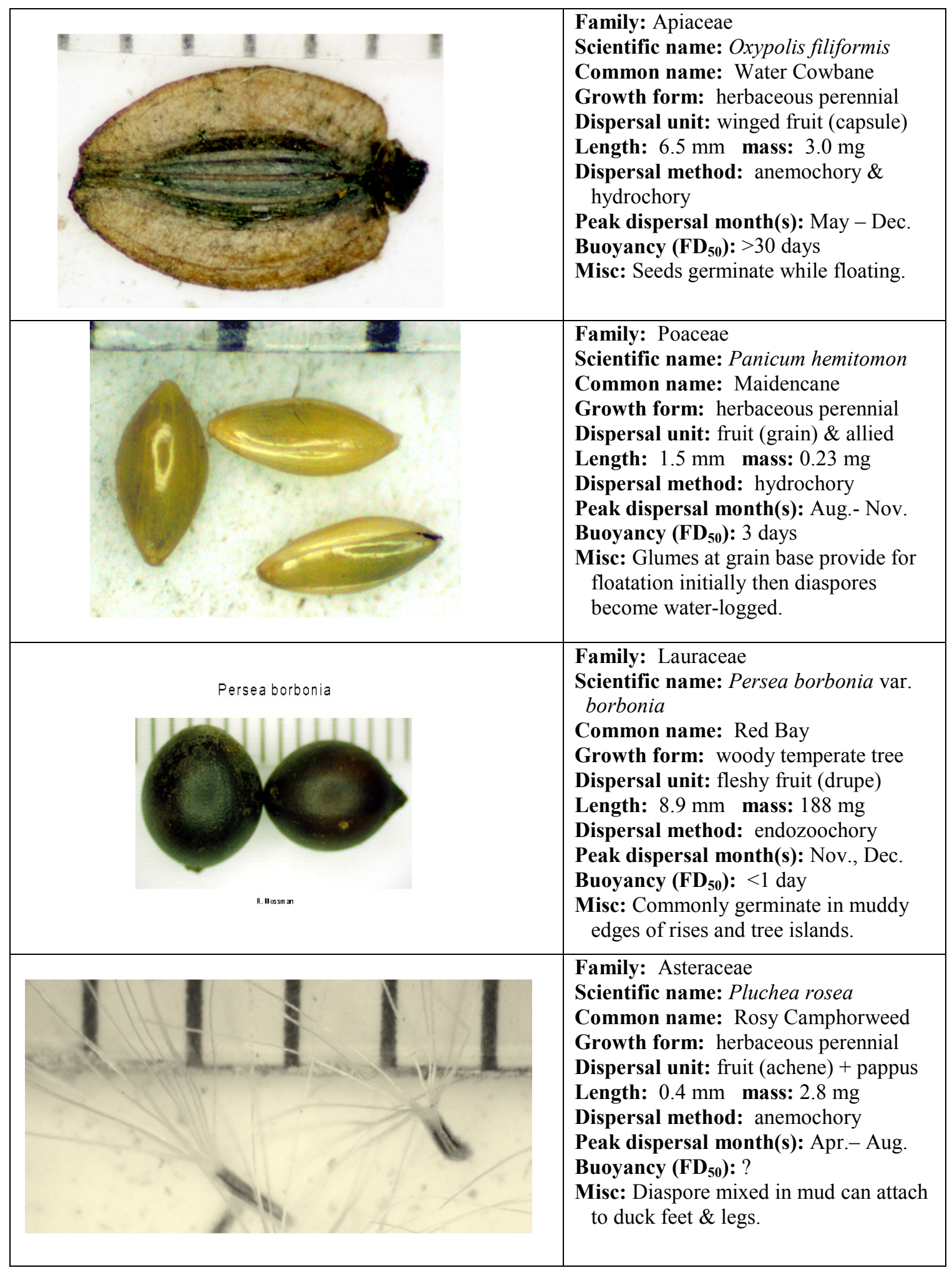




\begin{tabular}{|c|c|}
\hline\|\|\|\|\|\|\|\|\|\|\|\|\|\|$\|$ & $\begin{array}{l}\text { Family: Pontederiaceae } \\
\text { Scientific name: Pontederia cordata } \\
\text { Common name: Pickerelweed } \\
\text { Growth form: herbaceous perennial } \\
\text { Dispersal unit: fruit } \\
\text { Length: } 8.5 \mathrm{~mm} \text { mass: } 30.0 \mathrm{mg} \\
\text { Dispersal method: endozoochory + } \\
\text { hydrochory } \\
\text { Peak dispersal month(s): all year } \\
\text { Buoyancy (FD } \\
\text { Misc: } 14 \text { days } \\
\text { ducks. Seed exposed, right image. Seed } \\
\text { buoyant. }\end{array}$ \\
\hline $\begin{array}{llll}1 & 1 & 1 & 1\end{array}$ & $\begin{array}{l}\text { Family: Haloragaceae } \\
\text { Scientific name: Proserpinaca palustris } \\
\text { Common name: Marsh Mermaid Weed } \\
\text { Growth form: herbaceous perennial } \\
\text { Dispersal unit: fruit (achene) } \\
\text { Length: } 3.5 \mathrm{~mm} \text { mass: } 13.2 \mathrm{mg} \\
\text { Dispersal method: hydrochory, } \\
\text { endozoochory } \\
\text { Peak dispersal month(s): all year } \\
\text { Buoyancy }\left(\text { FD }_{\mathbf{5 0}}\right):>30 \text { days } \\
\text { Misc: }\end{array}$ \\
\hline$\sqrt{3}$ & $\begin{array}{l}\text { Family: Cyperaceae } \\
\text { Scientific name: Rhynchospora } \\
\text { colorata } \\
\text { Common name: Starrush, Whitetop } \\
\text { Beaksedge } \\
\text { Growth form: herbaceous perennial } \\
\text { Dispersal unit: fruit (achene) } \\
\text { Length: } 1.2 \mathrm{~mm} \text { mass: } 0.94 \mathrm{mg} \\
\text { Dispersal method: litter-assisted } \\
\text { hydrochory, epizoochory } \\
\text { Peak dispersal month(s): all year } \\
\text { Buoyancy (FD } \text { Fo }_{\mathbf{5 0}} \text { ): }<1 \text { day } \\
\text { Misc: fruit mixed in mud can attach to } \\
\text { duck feet \& legs. }\end{array}$ \\
\hline 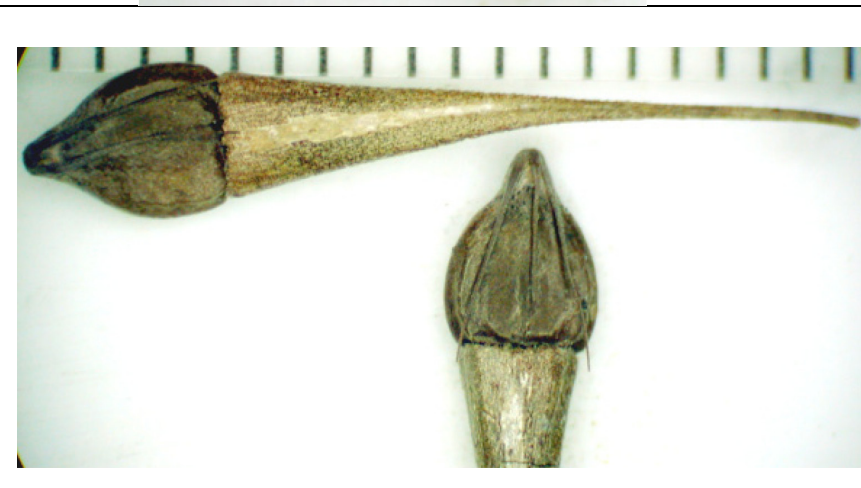 & $\begin{array}{l}\text { Family: Cyperaceae } \\
\text { Scientific name: Rhynchospora } \\
\text { inundata } \\
\text { Common name: Narrowfruit Horned } \\
\text { Beaksedge } \\
\text { Growth form: herbaceous perennial } \\
\text { Dispersal unit: fruit (achene) } \\
\text { Length: } 23.7 \mathrm{~mm} \text { mass: } 13.7 \mathrm{mg} \\
\text { Dispersal method: hydrochory } \\
\text { Peak dispersal month(s): Aug. - Nov. } \\
\text { Buoyancy (FD } \text { Fon }_{50} \text { : }>30 \text { days } \\
\text { Misc: enlarged beak enhances buoy. }\end{array}$ \\
\hline
\end{tabular}




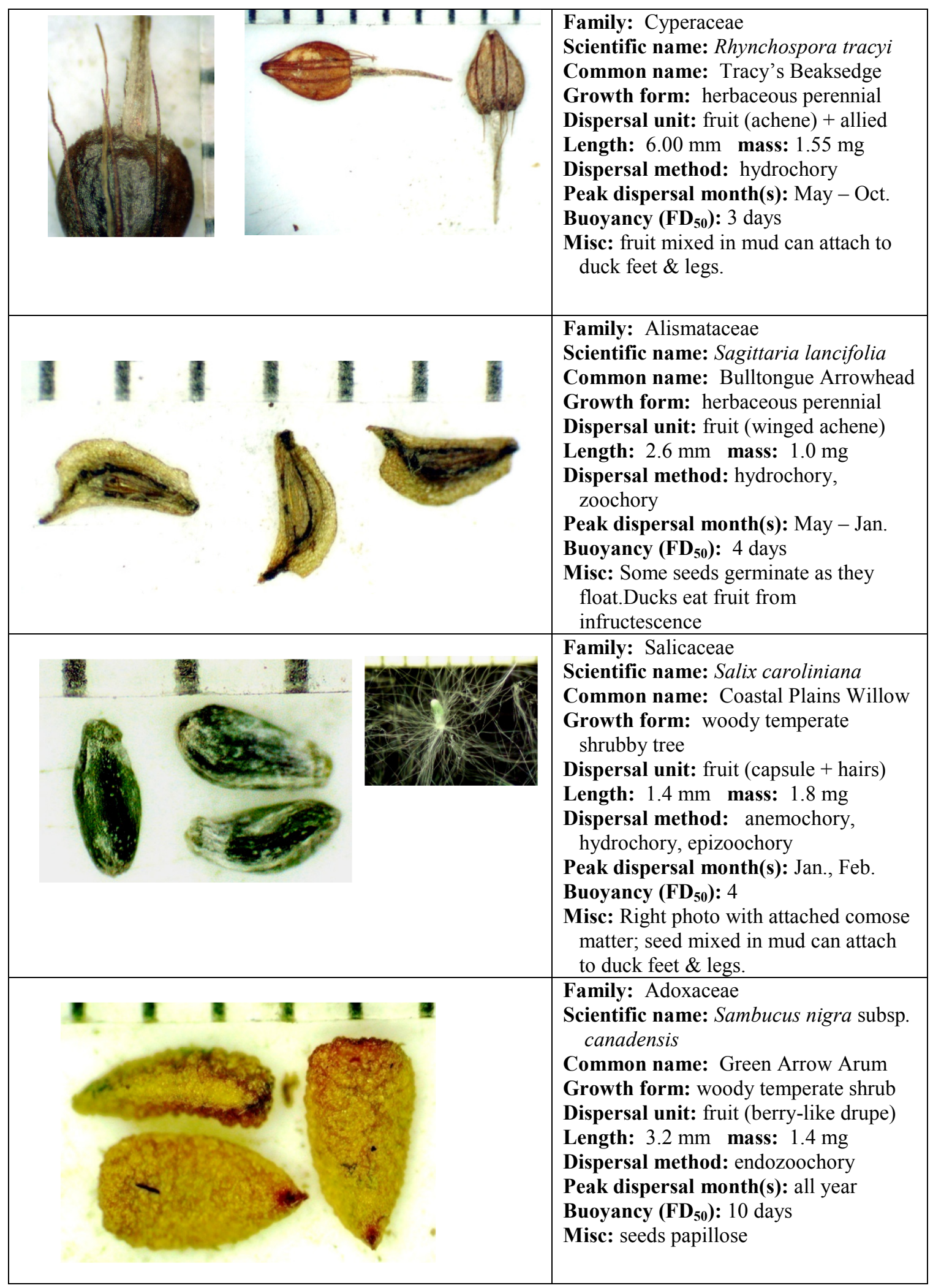




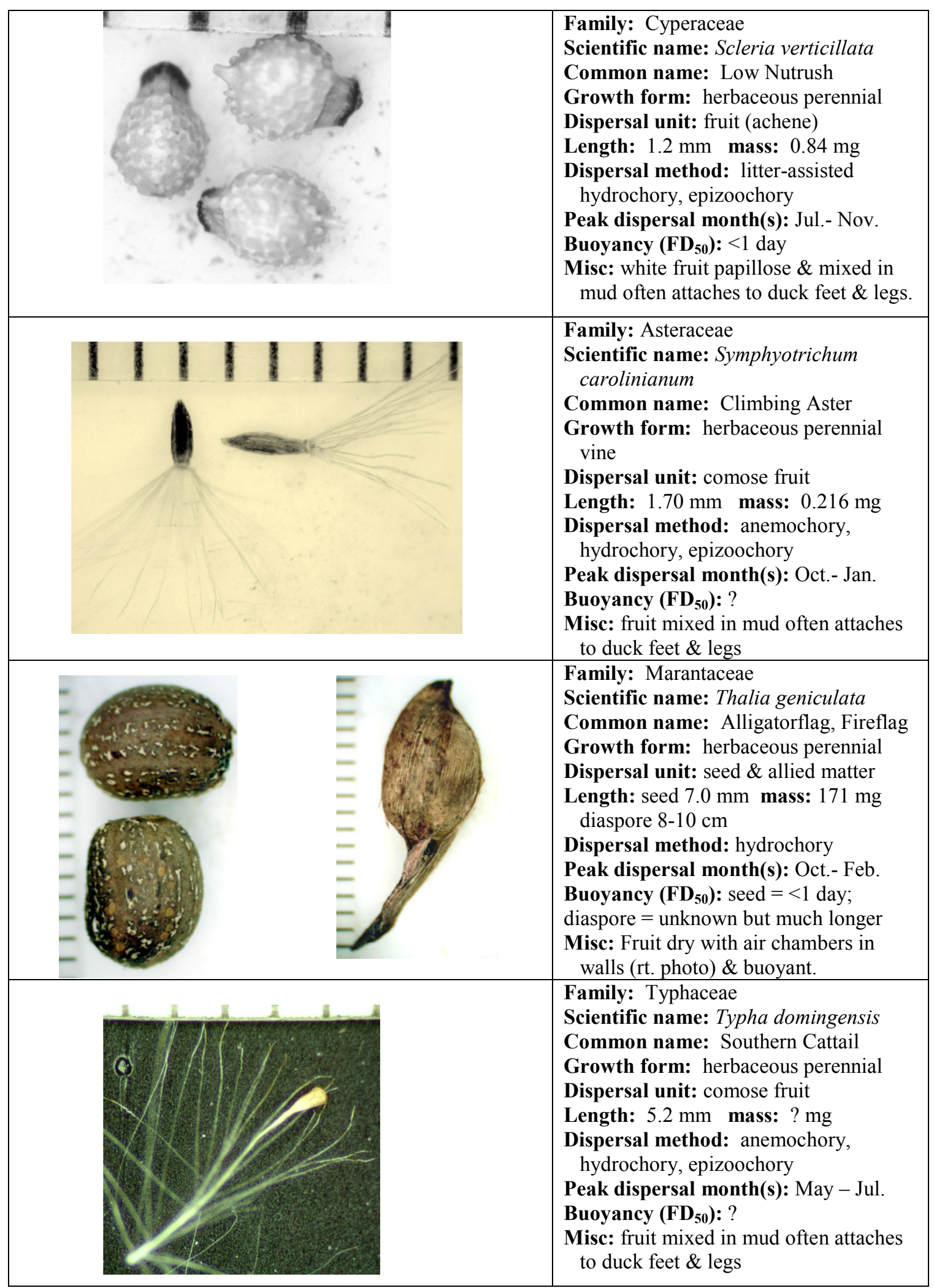




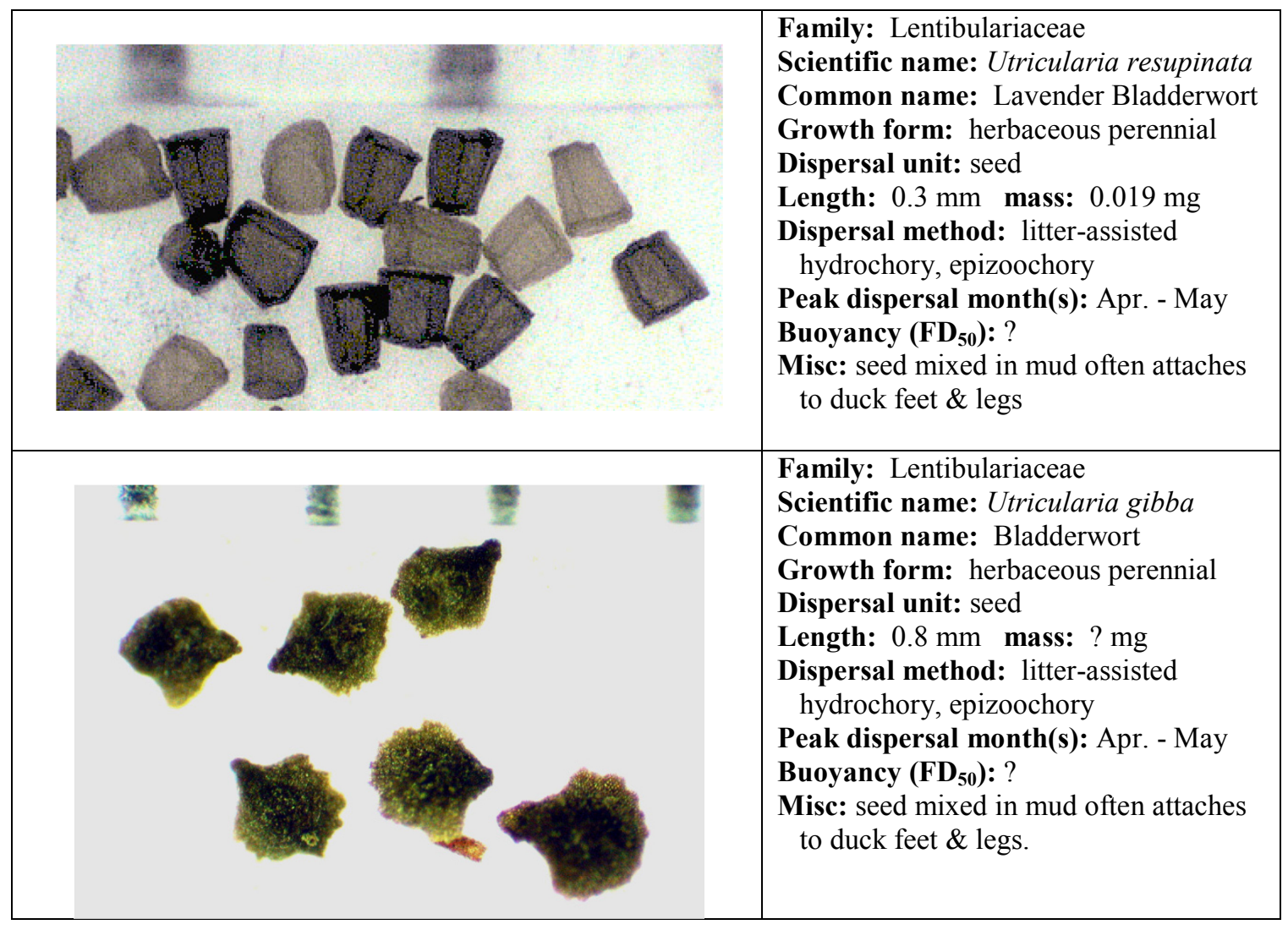


APPENDIX E Germination (seedling) assay and seed assay analyses in the Everglades. Here an attempt is made to determine the congruence of species from other Everglades seedbank studies. Only Angiosperms are included. Species in my study in common with historical Everglades species (Ref.), as listed in Smith et al. (2002) and Loveless (1959), are bolded. In the headings, $\mathbf{g}=$ germination assay. $\mathbf{s}=$ seed assay (intact seeds), Moss $=$ standing vegetation in vicinity of my seedbank study. See below for all other abbreviations.

\begin{tabular}{|c|c|c|c|c|c|c|c|c|c|c|c|}
\hline SPECIES & $\begin{array}{l}\text { Mo } \\
\text { (g) }\end{array}$ & $\begin{array}{c}\text { Mo } \\
\text { (s) }\end{array}$ & $\begin{array}{l}\text { Mi } \\
\text { (g) }\end{array}$ & $\begin{array}{l}\mathrm{R} \\
(\mathrm{g})\end{array}$ & $\begin{array}{c}V \\
\text { (g) }\end{array}$ & $\begin{array}{l}\mathrm{V} \\
\text { (s) }\end{array}$ & $\mathbf{L}$ & $\mathbf{S}$ & $\begin{array}{c}S \\
\text { Ref. }\end{array}$ & $\begin{array}{l}\text { Lov } \\
\text { Ref. }\end{array}$ & Moss \\
\hline Aeschynomene pratensis & & & & & & & & & & & $\mathrm{X}$ \\
\hline Amaranthus australis & & & $\mathrm{X}$ & & $\mathrm{X}$ & & $\mathrm{X}$ & & & & \\
\hline Annona glabra & & & & & & & & & & & $\mathrm{X}$ \\
\hline Asclepias lanceolata & & & & & & & & & & & $\mathrm{X}$ \\
\hline Bacopa caroliniana & $\mathbf{X}$ & & & $\mathbf{X}$ & & & & & $\mathbf{X}$ & $\mathbf{X}$ & $\mathbf{X}$ \\
\hline Bacopa monierii & $\mathrm{X}$ & & & & & & & & & & $\mathrm{X}$ \\
\hline Bulbostylis ciliatifolia & $\mathrm{X}$ & & & & & & & & & & $\mathrm{X}$ \\
\hline Carex sp. 1 & & & & & & $\mathrm{X}$ & & & & & \\
\hline Carex sp. 2 & & & & & & $\mathrm{X}$ & & & & & \\
\hline Centella erecta & & & & & & & $\mathrm{X}$ & & & & $\mathrm{X}$ \\
\hline $\begin{array}{l}\text { Cephalanthus } \\
\text { occidentalis }\end{array}$ & & & & & & & & & & $\mathrm{X}$ & $\mathrm{X}$ \\
\hline Chrysobalanus icaco & & & & & & & & & & & $\mathrm{X}$ \\
\hline Cladium jamaicensis & $\mathbf{X}$ & $\mathbf{X}$ & $\mathbf{X}$ & $\mathbf{X}$ & $\mathbf{X}$ & $\mathbf{X}$ & & & $\mathbf{X}$ & $\mathbf{X}$ & $\mathbf{X}$ \\
\hline Crinum americanum & & & $\mathrm{X}$ & $\mathrm{X}$ & & & & & $\mathrm{X}$ & $\mathrm{X}$ & $\mathrm{X}$ \\
\hline Cyperus haspan & & & & $\mathrm{X}$ & & & & $\mathrm{X}$ & $X$ & $X$ & \\
\hline Cyperus odoratus & & & $\mathrm{X}$ & & $\mathrm{X}$ & $\mathrm{X}$ & & $\mathrm{X}$ & & & $\mathrm{X}$ \\
\hline Cyperus sp. & & & & & & & $\mathrm{X}$ & & & & \\
\hline Eleocharis cellulosa & $\mathbf{X}$ & $\mathbf{X}$ & $\mathbf{X}$ & $\mathbf{X}$ & & & $\mathbf{X}$ & & $\mathbf{X}$ & $\mathbf{X}$ & $\mathbf{X}$ \\
\hline Eleocharis elongata & & & & $\mathrm{X}$ & $\mathrm{X}$ & $\mathrm{X}$ & & & $\mathrm{X}$ & $\mathrm{X}$ & \\
\hline Eleocharis interstincta & & & & & & & & & & & $\mathrm{X}$ \\
\hline Fimbristylis $s p$. & & & & & & $\mathrm{X}$ & & & & & \\
\hline $\begin{array}{l}\text { Dalbergia } \\
\text { ecastophyllum }\end{array}$ & & & & & & & & & & & $\bar{X}$ \\
\hline $\begin{array}{l}\text { Dichanthelium } \\
\text { (Panicum) } \\
\text { dichotomum }\end{array}$ & & & & & & & & $\mathrm{X}$ & & $\mathrm{X}$ & $\mathrm{X}$ \\
\hline Fuirena breviseta & & & & & & & & & & & $\mathrm{X}$ \\
\hline Fuirena cf. squarrosa & & & & & & $\mathrm{X}$ & & & & & \\
\hline Helenium pinatifidum & & & & & & & & & & & $\mathrm{X}$ \\
\hline Ilex cassine & & & & & & & & & & & $\mathrm{X}$ \\
\hline Ipomoea sagittata & & & & & & & & & $\mathrm{X}$ & $\mathrm{X}$ & $\mathrm{X}$ \\
\hline Juncus megacephalus & & & & & & & & & & & $\mathrm{X}$ \\
\hline
\end{tabular}




\begin{tabular}{|c|c|c|c|c|c|c|c|c|c|c|c|}
\hline (continued) SPECIES & $\begin{array}{l}\text { Mo } \\
\text { (g) }\end{array}$ & $\begin{array}{c}\text { Mo } \\
\text { (s) }\end{array}$ & $\begin{array}{l}\text { Mi } \\
\text { (g) }\end{array}$ & $\begin{array}{c}\mathbf{R} \\
(\mathrm{g})\end{array}$ & $\begin{array}{c}V \\
(g)\end{array}$ & $\begin{array}{c}V \\
(s)\end{array}$ & $\mathbf{L}$ & $\mathbf{S}$ & $\begin{array}{c}\text { S } \\
\text { Ref. }\end{array}$ & $\begin{array}{l}\text { Lov } \\
\text { Ref. }\end{array}$ & Moss \\
\hline Kosteletzkya virginica & & & & & & & $\mathrm{X}$ & & & $\mathrm{X}$ & $\mathrm{X}$ \\
\hline Ludwigia microcarpa & & & & & & & $\mathrm{X}$ & $\mathrm{X}$ & & & $\mathrm{X}$ \\
\hline Ludwigia repens & & & & & & & & & & & $\mathrm{X}$ \\
\hline Ludwigia sp. 1 & & & & $\mathrm{X}$ & & & & & & & \\
\hline Lemna sp. & & & & & $\mathrm{X}$ & & & & & $\mathrm{X}$ & \\
\hline Ludwigia sp. 2 & & & & $\mathrm{X}$ & & & & & & & \\
\hline Mikania scandens & & & $X$ & & $\mathrm{X}$ & $\mathrm{X}$ & & $\mathrm{X}$ & $X$ & $X$ & $\mathrm{X}$ \\
\hline $\begin{array}{l}\text { Morella (Myrica) } \\
\text { cerifera }\end{array}$ & & & & & & & & & & & $\mathrm{X}$ \\
\hline Nuphar luteum & & & & & & & & & & & $\mathrm{X}$ \\
\hline Nymphaea odorata & & & $\mathrm{X}$ & $\mathrm{X}$ & $\mathrm{X}$ & $\mathrm{X}$ & & & $\mathrm{X}$ & $\mathrm{X}$ & $\mathrm{X}$ \\
\hline Nymphoides aquaticum & & & & $\mathrm{X}$ & & & & & $\mathrm{X}$ & $\mathrm{X}$ & $\mathrm{X}$ \\
\hline Oxypolis filiformis & & & & & & & & & & $X$ & \\
\hline Panicum hemitomon & & & $\mathrm{X}$ & $\mathrm{X}$ & & & & & $\mathrm{X}$ & $\mathrm{X}$ & $\mathrm{X}$ \\
\hline Paspalidium geminatum & & & & & & & & & & $\mathrm{X}$ & $\mathrm{X}$ \\
\hline Peltandra virginica & & & & & & & & & & $\mathrm{X}$ & $\mathrm{X}$ \\
\hline Persea borbonia & & & & & & & & & & & $\mathrm{X}$ \\
\hline Pluchea rosea & & & & & & & $\mathrm{X}$ & & $\mathrm{X}$ & $\mathrm{X}$ & $\mathrm{X}$ \\
\hline Polygonum densiflorum & & & & & & $\mathrm{X}$ & & & & $\mathrm{X}$ & \\
\hline $\begin{array}{l}\text { Polygonum } \\
\text { hydropiperoides }\end{array}$ & $\mathbf{X}$ & & & & & & $\mathbf{X}$ & & $\mathbf{X}$ & $\mathbf{X}$ & $\mathbf{X}$ \\
\hline Polygonum punctatum & & & $X$ & & & $X$ & & & & $\mathrm{X}$ & \\
\hline Pontederia cordata & & & & & & & & & & $\mathrm{X}$ & $\mathrm{X}$ \\
\hline Proserpinaca palustris & & & & & & & & & & & $\mathrm{X}$ \\
\hline Rhynchospora colorata & & & & & & & $\mathrm{X}$ & & & $\mathrm{X}$ & $\mathrm{X}$ \\
\hline Rhynchospora divergens & & & & & & & $\mathrm{X}$ & & & & \\
\hline Rhynchospora inundata & & & & & & & $\mathrm{X}$ & & $\mathrm{X}$ & & $\mathrm{X}$ \\
\hline $\begin{array}{l}\text { Rhynchospora } \\
\text { microcarpa }\end{array}$ & & & & & & & $\mathrm{X}$ & $\mathrm{X}$ & $\mathrm{X}$ & & $\mathrm{X}$ \\
\hline Rhynchospora sp. 1 & & & & & & $\mathrm{X}$ & $\mathrm{X}$ & & & & \\
\hline Rhynchospora sp. 2 & & & & & & $\mathrm{X}$ & & & & & \\
\hline Rhynchospora tracyi & $\mathrm{X}$ & $X$ & & $\mathrm{X}$ & & $\mathrm{X}$ & & & $\mathrm{X}$ & $\mathrm{X}$ & $\mathrm{X}$ \\
\hline Sagittaria lancifolia & $\mathbf{X}$ & & & $\mathbf{X}$ & $\mathbf{X}$ & $\mathbf{X}$ & $\mathbf{X}$ & & $\mathbf{X}$ & $\mathbf{X}$ & $\mathbf{X}$ \\
\hline Salix caroliniana & & & & & & & & & & $\mathrm{X}$ & $\mathrm{X}$ \\
\hline $\begin{array}{l}\text { Symphyotrichum(Aster) } \\
\text { carolinianum }\end{array}$ & & & & & & & & & & & $\mathrm{X}$ \\
\hline Thalia geniculata & & & & & & & & & & & $\mathrm{X}$ \\
\hline Typha angustifolia & & & & & & & & & & $\mathrm{X}$ & \\
\hline Typha domingensis & $\mathrm{X}$ & & & & & & $\mathrm{X}$ & $\mathrm{X}$ & & $\mathrm{X}$ & $X$ \\
\hline Typhasp. & & & $\mathrm{X}$ & & $\mathrm{X}$ & $\mathrm{X}$ & & $\mathrm{X}$ & & & \\
\hline Utricularia foliosa & $\mathbf{X}$ & & & $\mathbf{X}$ & & & & & & $\mathbf{X}$ & $\mathbf{X}$ \\
\hline Utricularia gibba & $\mathrm{X}$ & & & $\mathrm{X}$ & & & & & & $\mathrm{X}$ & $\mathrm{X}$ \\
\hline Utricularia purpurata & $\mathrm{X}$ & & & & & & & & & $\mathbf{X}$ & $\mathbf{X}$ \\
\hline Utricularia resupinata & $\mathrm{X}$ & & & & & & & & & & $\mathbf{X}$ \\
\hline
\end{tabular}




\begin{tabular}{|l|c|c|c|c|c|c|c|c|c|c|c|}
\hline (continued) SPECIES & $\begin{array}{c}\text { Mo } \\
\text { (g) }\end{array}$ & $\begin{array}{c}\text { Mo } \\
(\mathbf{s})\end{array}$ & $\begin{array}{c}\text { Mi } \\
(\mathrm{g})\end{array}$ & $\begin{array}{c}\text { R } \\
(\mathrm{g})\end{array}$ & $\begin{array}{c}\text { V } \\
(\mathrm{g})\end{array}$ & $\begin{array}{c}\text { V } \\
(\mathbf{s})\end{array}$ & $\mathbf{L}$ & $\mathbf{S}$ & $\begin{array}{c}\text { S } \\
\text { Ref. }\end{array}$ & $\begin{array}{c}\text { Lov } \\
\text { Ref. }\end{array}$ & Moss \\
\hline Total Species & $\mathbf{1 3}$ & $\mathbf{3}$ & $\mathbf{1 9}$ & $\mathbf{1 3}$ & $\mathbf{9}$ & - & $\mathbf{2}$ & $\mathbf{3}$ & - & - & - \\
\hline $\begin{array}{l}\text { Species in common } \\
\text { with my germin. study: }\end{array}$ & - & - & $\mathbf{4}$ & $\mathbf{5}$ & $\mathbf{3}$ & - & $\mathbf{3}$ & $\mathbf{1}$ & $\mathbf{5}$ & $\mathbf{8}$ & - \\
\hline
\end{tabular}

Mo $=$ Mossman (unpublished 2003) data Shark Slough, ENP

Mi $=$ Miao and Zou (2009) conducted in WCA-2A (only south transect used here)

$\mathbf{R}=$ Richards and Coyne (unpublished 1997) conducted in WMA-3A;

$\mathbf{V}=$ van der Valk and Rosburg. (1997) conducted in WMA-2A along 3 transects in Typha, Transition, and Sawgrass communities at 13 sampling sites

$\mathbf{L}=$ Leeds et al . (2002) conducted in western WCA-2A along 3 N-S transects

$\mathbf{S}=$ Smith et al. (2002) Rotenberger Wildlife Mgmt. Area at 4 sites along each of 2 parallel transects (following future flow directions upon discharge from STA-5). Reference species list for Northern Everglades also published in document.

$\mathbf{L o v}=$ Vegetation of Historic Everglades (Loveless 1959)

Moss $=$ standing vegetation in NW Shark Slough 2003-2008 
APPENDIX F. Comparative seed data from five Everglades seed studies. All values are for seedling germination assays (seeds $/ \mathrm{m}^{2} \pm$ S.E.) unless stated otherwise. Only Angiosperm species are included in totals.

\begin{tabular}{|c|c|c|c|c|c|}
\hline $\begin{array}{c}\text { Species } \\
\text { and Totals }\end{array}$ & $\begin{array}{l}\text { Mossman } \\
\text { Shark Slough, } \\
\text { NW (ENP) } \\
\text { (mean site } \\
\text { density) }\end{array}$ & $\begin{array}{c}\text { van der Valk } \\
\text { \& Roseburg } \\
(1997) \\
\text { WCA-2A, } \\
\text { west (sawgrass } \\
\text { transect only) }\end{array}$ & $\begin{array}{c}\text { Leeds et al. } \\
\quad(2002) \\
\text { WCA-2A, east }\end{array}$ & $\begin{array}{c}\text { Smith et al. } \\
\text { (2006) } \\
\text { RWMA } \\
\text { (severely } \\
\text { degraded soils) }\end{array}$ & $\begin{array}{c}\text { Miao \& Zou } \\
(2009) \\
\text { WCA-2A } \\
\text { (south } \\
\text { transect) }\end{array}$ \\
\hline $\begin{array}{l}\text { Cladium } \\
\text { jamaicense }\end{array}$ & $42.2 \pm 0.4$ & 145 & $\begin{array}{l}0 \text { (May) } \\
0 \text { (Oct.) }\end{array}$ & $\begin{array}{c}0 \text { (March) } \\
0 \text { (Sept.) }\end{array}$ & $\mathrm{Y}$ \\
\hline $\begin{array}{l}\text { Eleocharis } \\
\text { cellulosa }\end{array}$ & $290.7 \pm 1.0$ & 0 & $\begin{array}{l}0.09 \\
0.19\end{array}$ & $\begin{array}{l}0 \\
0\end{array}$ & $\begin{array}{l}\text { Eleocharis } \\
\text { spp. }\end{array}$ \\
\hline $\begin{array}{l}\text { Rhynchospora } \\
\text { tracyi }\end{array}$ & $21.7 \pm 0.3$ & 0 & $\begin{array}{l}0 \\
0 \\
\end{array}$ & $\begin{array}{l}0 \\
0\end{array}$ & 0 \\
\hline $\begin{array}{l}\text { Sagittaria } \\
\text { lancifolia }\end{array}$ & $45.6 \pm 0.3$ & 16 & $\begin{array}{l}0.05 \\
0.14\end{array}$ & $\begin{array}{l}0 \\
0\end{array}$ & S. latifolia(?) \\
\hline $\begin{array}{l}\text { Typha } \\
\text { domingensis, } \\
\text { T. angustifolia }\end{array}$ & $\begin{array}{c}\text { Typdom } 16.0 \\
\pm 0.2\end{array}$ & Typha spp. 16 & $\begin{array}{ll}\text { Typdom } & 0.02 \\
\text { Typdom } & 0.92\end{array}$ & $\begin{array}{l}\text { Typha sp. } 4 \\
\text { Typha sp } 1\end{array}$ & T. latifolia(?) \\
\hline $\begin{array}{c}\text { Mean Densities } \\
\text { for Germination } \\
\text { Study }\end{array}$ & $486 \pm 67$ S.E. & 274 & $\begin{array}{r}586 \\
422 \text { (May) \& } \\
751 \text { (Sept.) } \\
\end{array}$ & $\begin{array}{r}1173 \\
1,249 \text { (Mar.) \& } \\
1,529 \text { (Sept.) } \\
\end{array}$ & $\begin{array}{r}296-497 \\
\text { More pristine } \\
\text { transect }\end{array}$ \\
\hline $\begin{array}{c}\text { Mean Density } \\
\text { for Seed Assay } \\
\text { Study }\end{array}$ & $\begin{array}{r}370 \pm 82 \text { S.E. } \\
(25 \text { of } 90 \\
\text { selected soil } \\
\text { samples })\end{array}$ & 14,400 & -- & -- & -- \\
\hline $\begin{array}{c}\text { Seedbank } \\
\text { Resembles } \\
\text { Standing } \\
\text { Vegetation (Y/N) }\end{array}$ & $\mathrm{Y}$ & $\mathrm{N}$ & $?$ & $\mathrm{~N}$ & $?$ \\
\hline $\begin{array}{c}\text { Number of } \\
\text { Species \& } \\
\text { Collection Dates }\end{array}$ & 13 (Jan.) & $\begin{array}{r}\text { (Oct.-Nov.) } \\
\text { (sawgrass } \\
\text { transect only) }\end{array}$ & $\begin{array}{r}17 \text { (May) } \\
23 \text { (Oct) }\end{array}$ & $\begin{array}{l}21 \text { (Mar.) } \\
29 \text { (Sept.) }\end{array}$ & 18 \\
\hline
\end{tabular}


VITA

RONALD E. MOSSMAN

November 2009

\section{EDUCATION}

1965

1972

$1972-1975$

1998-2009
B.S. Zoology (Pre-Medicine), Ohio University, Athens, OH

M.S. Botany (Taxonomy \& Ecology), Ohio State Univ., Columbus, OH

Doctoral level coursework and research (aquatic plant ecology) (Part Time), University of Miami, Coral Gables, FL

Doctoral Program, Biology (Part-time) - Seed Ecology in the Everglades, Florida International University, Miami, FL

\section{EMPLOYMENT}

I. College Level

1973 - 1985 Adjunct Biology Instructor (Part Time), Miami-Dade Community College

1985 - 2007 Miami Dade College, Kendall Campus, Miami, Florida (Full Time)

Teaching: Biology and Landscape Technology courses

Administrative: Director of Landscape Technology Program.

Chairman, Campus Landscape Committee

2007-Present Adjunct Instructor Part Time), Florida International University, Landscape

Architecture Program, Miami, FL. Tropical Landscapes, South Florida

Landscapes, Theory of Planting Design

\section{Secondary Level}

Teaching

1966 - 1967 Science teacher (Circleville, OH): Chemistry \& Physics

1967 - 1969 Chair Science Dept., Republic of Panama \& teacher of: Botany \& Biology.

1970 - 1971 Science teacher, Oberlin, OH: Biology \& Physical Science

1973 - 1984 Science teacher (Dade Co. Florida): Chemistry, Biology, Physics

Chair Science Department, 8 years.

Administrative

1984 - 1985 Science Supervisor, Dade County Public Schools, North Area (60 schools).

\section{CONSULTING}

1972 Taxonomic evaluation of James Duke plant collection, Republic of Panama Sea Level Canal study

1991-2005 Design and installation of ecological restoration areas, Miami Dade College,

Kendall

1992-2008 Wetland mitigation consulting

1993-95 Homestead Habitat for Humanity sustainable landscape design plans

1995 Land Reclamation Project Proposal for Government of the Grand Turks \& Caicos Islands

2006 Environmental science educational program plan at Kampong, Miami, FL

2006-07 Miami Dade College, Kendall Campus Arboretum design and installation

2007 Agroecology nursery consultant, Haiti.

2009 Miami-Dade County: updating of taxonomy in The Miami-Dade County Landscape

Manual

PUBLICATIONS

1972. A Floristic and Ecological Evaluation of Camden (Bog) Lake, Lorain County, Ohio. M.S. Thesis, Ohio State University. 
1975. Key to the Aquatic Plants of South Florida Using Vegetative Characters, University Miami

1984. Lake Landscaping with Native Aquatic Plants. Fairchild Tropical Garden Bulletin 39:615.

1993. Sustainable Landscaping in South Florida, a computer-assisted video disk for use in environmental science and landscaping classes. Miami Dade College

\section{LECTURES}

1972 Ohio Academy of Science, Marietta, OH: Phytohistorical patterns at Camden (Bog) Lake, Lorain Co., Ohio

1990's South Florida Native Plant Society: 4 lectures on use of native plants in urban landscapes

1991-2004 Flowering Tree Society lectures: Evolution of Delonix regia; Flowering Vines for South Florida; Acanthaceae; New Hybrids of Hamelia patens and H. cuprea

1991-95 Planner and lecturer to Latin American A.I.D. recipients,landscape nursery workshops (In English and Spanish).

2008 Agroecology Workshop, F.I.U., Sustainable Urban Landscaping: The Edible Landscape

2009 Fairchild Tropical Botanical Garden: Edible Plants in the Urban Landscape

2009 State Native Plant Society, West Palm Beach, FL: Searching for species attributes that contribute to dispersal

2009, 2008, 2006 South Florida Plant Biologists 1) Algal Mat Dynamics in the Everglades: Implications for Fish and Seeds, 2) Seed Dispersal in the Everglades, 3) Seed Dispersal Syndromes in the Everglades

\section{AWARDS AND GRANTS}

1972-73 N.I.H. Environmental Sciences Fellowship, University Miami 1997 Howard Hughes Bridge Grant (Univ. Miami \& M-DCC) Professional Sabbatical leave. 1989-90 Outstanding Teacher of Biology, Miami-Dade Community College, Kendall Campus 2002 Professional Development Leave, M-DCC. Fieldwork on Everglades marsh seed banks. 2002-07 Howard Hughes Bridge Grant. Funding for F.I.U. Ph.D. research in Everglades

\section{MEMBER}

National Science Teachers Association, Society for Ecological Restoration, Native Plant Society, Fairchild Tropical Botanical Garden, Tropical Flowering Tree Society, National Tropical Botanical Gardens, Friends of Chapman Field (Board), Friends of Everglades (Board), Botanical Society of America, Community Gardens of Miami-Dade County (Board)

\section{TRAVEL}

1967-70, 2008 Republic of Panama: Teaching, travel, and ecosystem studies

1968 Costa Rica: Spanish Language School and travels .

1986 People's Rep. of China with Fla. State Horticulture Society: Beijing (Nat. Veg. Institute), Shanghai (commune raising oranges), Xian, Guangzhou/Canton (botanical garden, horticultural nursery), \& Hong Kong

1994 Costa Rica, Rio Sierpe area: Site evaluation of ecological field station site, 1998 Great Britain \& France: Survey of landscape design and historical botanical gardens 2003 Hawaii: National Tropical Botanical Gardens, appropriate ecological plant usage 